GÖTTINGER ZENTRUM

FÜR BIODIVERSITÄTSFORSCHUNG UND ÖKOLOGIE

- Göttingen Centre for Biodiversity ANd ECOlogy -

\title{
Fine root dynamics in broad-leaved deciduous forest stands differing in tree species diversity
}

\author{
Dissertation zur Erlangung des Doktorgrades der \\ Mathematisch-Naturwissenschaftlichen Fakultäten der \\ Georg-August-Universität Göttingen
}

vorgelegt von

Catharina Meinen

aus

Wesel

Göttingen, August 2008 
Referent: Prof. Dr. Ch. Leuschner

Korreferent: Prof. Dr. D. Hölscher

Tag der mündlichen Prüfung: 


\section{Table of contents}

$\begin{array}{ll}\text { Summary } & 1\end{array}$

1. Introduction 3

1.1 The influence of biodiversity on ecosystem functioning 4

1.2 The effects of species diversity on below-ground processes 6

$\begin{array}{lll}1.3 & \text { Study site } & 7\end{array}$

1.4 Study design 9

$\begin{array}{lll}1.5 & \text { Study objectives and hypotheses } & 10\end{array}$

$\begin{array}{lll}1.6 & \text { References } & 11\end{array}$

2. Fine root biomass and morphology in temperate broad-leaved forests differing in tree species diversity - is there evidence of overyielding? 17

$\begin{array}{lll}2.1 & \text { Abstract } & 18\end{array}$

$\begin{array}{lll}2.2 & \text { Introduction } & 19\end{array}$

2.3 Materials and methods 21

2.4 Results 24

2.5 Discussion 31

2.6 References 38

3. No evidence of spatial root system segregation and elevated root biomass in speciesrich temperate broad-leaved forests

3.1 Abstract 46

$\begin{array}{lll}3.2 & \text { Introduction } & 47\end{array}$

3.3 Materials and methods 48

3.4 Results $\quad 52$

$\begin{array}{lll}3.5 & \text { Discussion } & 58\end{array}$

$\begin{array}{lll}3.6 & \text { References } & 62\end{array}$

4. Is the root system of species-rich forests more productive and more resilient after disturbance than that of monocultures? 65

$\begin{array}{lll}4.1 & \text { Abstract } & 66\end{array}$

$\begin{array}{lll}4.2 & \text { Introduction } & 67\end{array}$

$\begin{array}{lll}4.3 & \text { Materials and methods } & 68\end{array}$

$\begin{array}{lll}4.4 & \text { Results } & 74\end{array}$

$\begin{array}{lll}4.5 & \text { Discussion } & 79\end{array}$

$\begin{array}{lll}4.6 & \text { References } & 84\end{array}$ 
$\begin{array}{lr}\text { 5. Synthesis } & 89\end{array}$

5.1 Has tree species diversity an effect on below-ground processes? 90

5.2 Are there indicators for spatial niche-partitioning in the rhizosphere? 93

5.3 Does tree species diversity enhance fine root resilience? 94

5.4 References 96

$\begin{array}{lr}\text { 6. Appendix } & 99\end{array}$

$\begin{array}{ll}\text { Acknowledgements } & 103\end{array}$

$\begin{array}{ll}\text { Curriculum vitae } & 105\end{array}$ 


\section{Summary}

Biodiversity effects on ecosystem functioning in forests have attracted increasing attention only recently. The vast majority of studies in forests focussed on above-ground responses to differences in tree species diversity, while systematic analyses of the effects of biodiversity on root systems are virtually missing. By investigating the tree fine root systems in 12 temperate deciduous forest stands in the Hainich National Park (Thuringia, Germany), we tested the hypotheses that (i) stand fine root biomass increases with increasing tree species diversity, (ii) that tree species mixtures result in a spatial segregation of the fine root systems of different tree species, (iii) that seasonal changes in fine root mass are more pronounced in tree species-poor than in tree species-rich stands, and that (iv) productivity and resilience of the fine root system (i.e. recovery after disturbance) increase with increasing tree species diversity.

The selected 12 forest stands represent a gradient in tree species diversity on similar bedrock from almost pure beech forests to medium-diverse forests built by beech, ash, and lime, and to highly-diverse stands dominated by beech, ash, lime, maple, and hornbeam. We used a morphological key to identify the fine roots of the different tree species by colour, periderm surface structure and branching patterns. We investigated fine root bioand necromass and their spatial distribution patterns at 24 profiles per stand and analysed species differences in fine root morphology by microscopic analysis. Furthermore, the seasonal changes in fine root bio- and necromass were recorded during a 12-month period and fine root productivity was estimated with two independent approaches (ingrowth cores, sequential coring).

Fine root biomass ranged from 440 to $480 \mathrm{~g} \mathrm{~m}^{-2}$ in the monospecific to the 5 -species stands, with $63-77 \%$ being concentrated in the upper $20 \mathrm{~cm}$ of the soil. In all tree species present, fine root density (biomass per soil volume) decreased exponentially with soil depth at very similar rates. Moreover, indications of a spatial segregation of the root systems of different species in the species-rich stands were not found. Fine root morphology showed marked distinctions between tree species, but these root morphological differences did not lead to significant differences in fine root surface area or root tip abundance on a stand area basis. Moreover, differences in tree species composition of the stands did not alter fine root morphology of the species. According to the analysis of 360 ingrowth cores, fine root growth into the root-free soil increased with tree species diversity from $72 \mathrm{~g} \mathrm{~m}^{-2} \mathrm{yr}^{-1}$ in the monospecific plots to $166 \mathrm{~g} \mathrm{~m}^{-2} \mathrm{yr}^{-1}$ in the 5-species 
plots indicating a more rapid recovery of the root system after soil disturbance in the species-rich stands. Fine root productivity as approximated by the sequential coring data also indicated a roughly threefold increase from the monospecific to the 5-species stand. We found no indication of a more pronounced seasonality of fine root mass in species-poor as compared to species-rich stands.

We conclude that 'overyielding' in terms of fine root biomass does not occur in the speciesrich stands, which is most likely caused by the absence of significant spatial segregation of the root systems of these late-successional species. Our study produced first evidence in support of the hypothesis that more diverse forest stands are more resilient after soil disturbance, and perhaps more productive, in their fine root system than species-poor forests. Species identification on the fine root level, as conducted here, may open new perspectives in further studies focusing on tree species effects on root dynamics. 
CHAPTER

Introduction 


\subsection{The influence of biodiversity on ecosystem functioning}

Biological diversity or biodiversity is the variety of life, which includes not only species diversity, but also genetic variability and the variety of habitats (Convention on Biological Diversity 1992). Besides many direct use values (e.g. food, medicine, biological control) of biological diversity, it has also been shown that biodiversity (in the term of species richness) affects ecosystem processes such as plant biomass production, decomposition and nutrient cycling (e.g. Chapin et al. 1997, 2000; Loreau 2000; Hooper et al. 2005; Gamfeldt et al. 2008). Next to the null hypothesis of no effect between biodiversity and ecosystem functioning, mainly four hypotheses (insurancereliability hypothesis, niche-complementarity hypothesis, redundant species hypothesis, and idiosyncratic response hypothesis) out of more than 50 hypotheses have been stated (Gaston \& Spicer 2002) and tested in several experiments in the context of biodiversity and ecosystem processes and functions (e.g. Ehrlicher \& Ehrlicher 1981; Walker 1992; Naeem et al. 1994; Tilman \& Downing 1994; Johnson et al. 1996; Tilman et al. 1996).

- The insurance-reliability hypothesis predicts that ecological communities decrease their ability to recover from disturbance and reduce their productivity with decreasing number of species.

- The niche-complementary hypothesis states that species are more or less unique in their functional relevancy and a loss of species will cause a reduction of ecosystem functioning.

- According to the redundant species hypothesis species are subdivided into functional groups and species loss has only little impact on ecosystem functioning when representative species remain present in all functional groups. Thus, only minimal diversity is necessary to ensure ecosystem functions and most species are redundant in their role.

- The idiosyncratic hypothesis implies that ecosystem functioning changes with decreasing diversity. The direction and the magnitude of the change are unpredictable, because of the different tasks and functions of individual species.

Species diversity can also enhance the ability of resilience after disturbance in ecosystems (Peterson et al. 1998; Chapin et al. 2000; Elmqvist et al. 2003). Results from a literature review revealed that mixed forest stands showed a higher resistance against disturbance than pure stands (Knoke et al. 2008), for example tree species 
growing in mixtures were less affected by pest damage than those in pure stands (Jactel et al. 2005).

Biodiversity can be measured in many ways, but in the majority of studies, species richness is often used as the most practicable parameter and has become a common currency of biodiversity studies (Gaston \& Spicer 2002). The relationship between species richness and ecosystem functioning e.g. above-ground biomass production was almost exclusively studied in grasslands, where species richness showed a positive relationship to plant biomass production in the majority of the experiments (e.g Tilman et al. 1996; Hooper \& Vitousek 1997; Hector 2001; Schmid et al. 2001). A more pronounced niche complementarity (as caused by species differences in rooting depth or light use efficiency) is assumed to be one reason for a higher productivity in speciesrich communities as compared to monocultures (Parrish \& Bazzaz 1976; Hector et al. 1999; Hector 2001). Interestingly, the strongest effects of species richness on productivity were found in ecosystems with a relatively low number of species (Tilman et al. 1996; Joliffe 1997; Hector et al. 1999).

In contrast to synthetic grassland communities, the positive effects of species richness on ecosystem functioning have rarely been studied in forests and the few existing investigations yielded contradictory results (Pretzsch 2005). Some studies revealed a higher above-ground biomass in mixed compared to single tree species stands (e.g. Brown 1992; Morgan et al. 1992; Bauhus et al. 2000; Erskine et al. 2006), while others found no effect of tree species diversity on biomass and productivity or even negative effects (Smith \& Long 1992; Yanai 1992; Enquist \& Niklas 2001; Vilà et al. 2003; Szwagrzyk \& Gazda 2007). Not only tree species richness, but also site conditions and silvicultural treatments influence the productivity of tree species mixtures (Lindén \& Agestam 2003; Légaré et al. 2005; Pretzsch 2005). Norway spruce (Picea abies), Pyrenean Scots pine (Pinus sylvestris), and Douglas fir (Pseudotsuga menziesii) were more productive in monocultures than in mixtures (Wiedemann 1949; Assmann 1970; Schober 1995), whereas Aleppo pine (Pinus halepensis) showed a higher productivity in stands with up to five admixed tree species (Vilà et al. 2003). Similarly to grassland ecosystems, tree species mixtures with similar ecological niches do not show higher rates of productivity (Chen \& Klinka 2003).

Yet, von Cotta (1828, translated by Pretzsch 2005, p. 42) stated '... since not all tree species utilize resources in the same manner, growth is more lively in mixed stands...'. In fact, complementary use of resources can lead to elevated production in mixed forest 
stands in certain cases (Pretzsch 2005; Knoke 2008). Investigations in forests were mainly restricted to mixtures consisting of two tree species (Kelty 1992; Pretzsch 2005), and focused almost exclusively on diversity effects on wood production (Vilà et al. 2003). Experimental tree plantations in boreal, temperate and tropical regions with a focus on biodiversity effects have been established only recently in Finland, Germany, Panama, China, and Malaysia (detailed information in Scherer-Lorenzen et al. 2005). In general, experimental plantations with trees have shortcomings and limitations such as equal stand age, which is highly artificial as compared to natural stands. Furthermore, they are highly cost intensive in maintenance (Scherer-Lorenzen et al. 2005). However, those experiments give scientists the much-needed opportunity to expand their knowledge on biodiversity effects in woody plant communities. The difficulty of testing the functional role of forest diversity is discussed in detail by Leuschner et al. (2008), who recommended a combination of comparative studies in mature forest stands like the 'Hainich Tree Diversity Matrix' with results from investigations in synthetic stands.

\subsection{The effects of species diversity on below-ground processes}

The majority of biodiversity experiments focused on the effects of species diversity on above-ground processes. Only few studies were conducted to investigate the impact of increasing plant diversity on below-ground processes such as fine root dynamics. Tree fine roots $(<2 \mathrm{~mm}$ in diameter) are important tree organs and responsible for the water and nutrient uptake. In temperate forests of Central Europe, about $1.2 \mathrm{t}$ of carbon per hectare are assumed to be stored in fine roots (Brunner \& Godbold 2007). For their maintenance and growth, trees may use up to $50 \%$ of the fixed carbon (Fogel \& Hunt 1983; Vogt et al. 1996).

Results from biodiversity experiments in grasslands revealed no effects of plant species richness on root mass (Hooper \& Vitousek 1997; Scherer-Lorenzen 1999; Spehn et al. 2000; Gastine et al. 2003), while comparable investigations in forests with more than two tree species are lacking. Comparisons of fine root mass in monospecific forest stands with two-species stands gave contradictory results. While some investigations in tropical forests indicate that fine root biomass is higher in mixtures than in monocultures (Berish \& Ewel 1988; Cuevas et al. 1991) or in temperate forests (Hendriks \& Bianchi 1995; Schmid 2002; Schmid \& Kazda 2002), in other studies, no effect or even a decrease of fine root biomass in tree species mixtures was found 
(Morgan 1992; Hertel 1999; Leuschner et al. 2001; Bauhus et al. 2000). Hendriks \& Bianchi (1995), Schmid (2002) and Schmid \& Kazda (2002) found that a higher fine root biomass in mixed stands was associated with a vertical fine root segregation of the occurring tree species. Similarly, Büttner \& Leuschner (1994) reported about belowground niche-partitioning in a Central European beech-oak forest stand and Bolte \& Villanueva (2006) observed that beech roots shifted into deeper soil layers in a beechspruce stand. Casper \& Jackson (1997) stated that niche separation in terms of different rooting depths can reduce interspecific below-ground competition. Not only vertical rooting patterns of trees, but also the horizontal extent of the tree fine root system is poorly studied in mixed forests. A major obstacle is the difficulty to identify fine roots of different tree species. This fact hampers the analysis of species-specific root distribution patterns in tree species-rich forest stands. We are aware of only a few studies in mixed forest stands, in which tree species identification on the basis of fine roots was applied (Hertel 1999; Hölscher et al. 2002; Korn 2004; Rewald \& Leuschner submitted). In one of these studies, Hölscher et al. (2002) found almost no lateral fine root overlap due to physical rooting barriers in the soil, whereas Hertel (1999), Korn (2004) and Rewald \& Leuschner (submitted) reported about a strong horizontal fine root overlap with $75 \%$ of the soil samples containing more than two tree species. As much as the vertical rooting pattern, the horizontal root extension of a plant determines its dimension of below-ground interactions with neighbouring plants (Casper \& Jackson 1997) and therefore, the degree of intra- and interspecific competition processes. In the present study, we were able to identify tree fine roots according to species which gave us the possibility to study the effects of tree species diversity on fine root dynamics in replicated plots along a gradient of tree species diversity $(1,3$, or 5 tree species) in the Hainich National Park (Thuringia, Germany).

\subsection{Study site}

The study was conducted in an old-growth broad-leaved forest in the Hainich National Park (Thuringia, Germany). European beech (Fagus sylvatica L.) is the dominant tree species in large areas of the National Park, but up to 14 tree species coexist in some parts which is a consequence of former management practice. 
The selected plots represented old-growth forest stands with a closed canopy. The mean tree age averaged about $100 \mathrm{yr}$; however, Fagus trees in the DL 1 plots were older (146 yr on average). The canopy height in the plots ranged from $26 \mathrm{~m}$ in the DL 3 plots to 38 $\mathrm{m}$ in plots of DL 1 . The basal areas were similar between the plots, but stem densities were somewhat higher on the plots of DL 2. The Shannon index increased from 0.2 in the almost monospecific beech plots to 1.8 in the plots of DL 3 . The annual mean air temperature averaged at about $7.5^{\circ} \mathrm{C}$ and annual precipitation was $670 \mathrm{~mm}$ (data of the nearby weather station Weberstedt/Hainich). The parent material of all plots was Triassic limestone covered by loess (minimum depth of $60 \mathrm{~cm}$ ). The soil type of the plots was a Luvisol (WRB 2006 taxonomy) with stagnic properties in spring and winter and a dryer period in summer. The $\mathrm{pH}\left(\mathrm{H}_{2} \mathrm{O}\right)$ value in $0-10 \mathrm{~cm}$ soil depth ranged from 4.6 in the DL 1 plots to 6.7 in the plots of DL 3. Hence, base saturation was particularly low in the DL 1 plots. A detailed description of the selection criteria for the study plots is given in Leuschner et al. (2008).

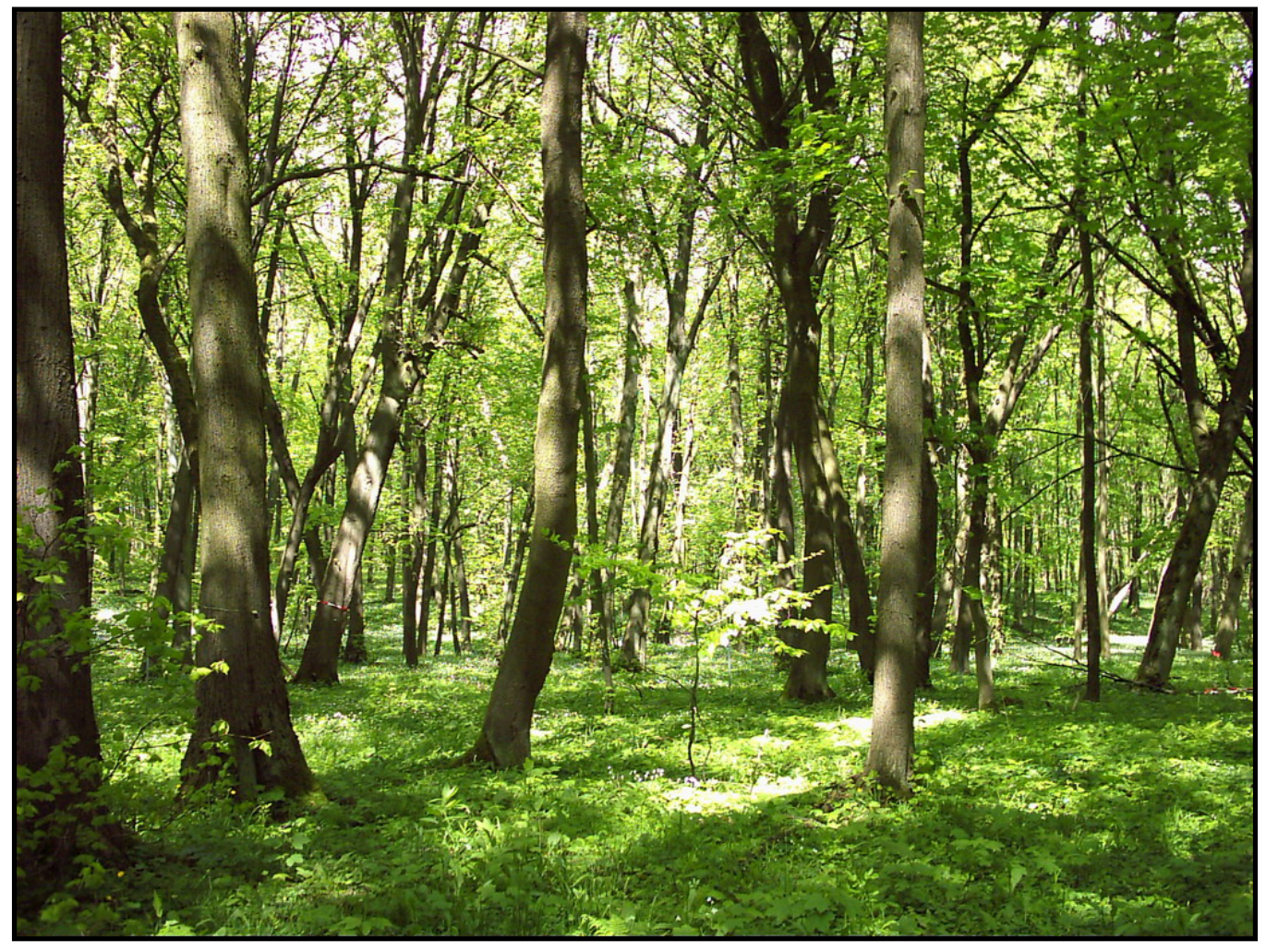

Figure 1.1 Species-rich forest stand in the Hainich National Park 


\subsection{Study design}

In total, 12 study plots $(50 \mathrm{~m} \times 50 \mathrm{~m})$ in the north-east of the National Park were selected which included areas with low, medium, and high tree species diversity. Plots of diversity level 1 (DL 1) were characterised mainly by Fagus sylvatica ( $>95 \%$ of total basal area). Plots of diversity level 2 (DL 2) were formed by Fagus s., Tilia sp. (T. cordata Mill. and T. platyphyllos Scop.) and Fraxinus excelsior L. The diversity level 3 (DL 3) plots were built by Fagus s., Tilia sp., Fraxinus e., Carpinus betulus L. and Acer sp. (A. pseudoplatanus L. and A. platanoides L.) (Figure 1.1). Additional tree species such as Acer campestre L., Prunus avium L., Quercus robur L., Q. petraea Liebl. and Ulmus glabra L. occurred occasionally in some plots. Four study plots per diversity level were selected as replicates. Three transects of $30 \mathrm{~m} \times 1 \mathrm{~m}$ were installed in every plot. 24 to 30 sampling locations (8-10 per transect) were selected by random in each of the plots.

In this study, the following parameters were investigated:

- Standing fine root bio- and necromass of trees and herbs

- Vertical and horizontal fine root distribution

- Morphological parameters of the fine root:

o Mean diameter

o Specific surface area

o Root tip abundance

- Root area index

- Seasonal changes in fine root bio- and necromass

- Fine root production estimated by the

o Minimum-maximum approach

o Ingrowth core approach

- Soil temperate at 5,15 , and $30 \mathrm{~cm}$ soil depth

Fine root mass was not only separated into live and dead fractions, but also identified according to species (Appendix 1). This approach offered new perspectives in the field of biodiversity studies regarding fine root dynamics in mixed stands. 


\subsection{Study objectives and hypotheses}

This study was conducted within the Research Training Group ('Graduiertenkolleg') 1086 'The role of biodiversity for biogeochemical cycles and biotic interactions in temperate deciduous forests' funded by the DFG (Deutsche Forschungsgemeinschaft). This interdisciplinary research group consists of $14 \mathrm{PhD}$ students, who investigate ecosystem functioning in temperate forests with contrasting tree species diversity.

In my $\mathrm{PhD}$ study, I focused on the effects of tree species diversity on the fine root systems in deciduous broad-leaved forest stands differing in tree species diversity.

The aims of my work were:

(1) to quantify standing fine root bio- and necromass and the contribution of the different tree species and tree saplings to the total fine root mass

(2) to identify differences in fine root morphological traits between the tree species

(3) to assess the evidence of spatial (vertical and horizontal) niche differentiation below-ground

(4) to investigate fine root phenology and

(5) to quantify fine root production with two different approaches along the diversity gradient

In Chapter 2, we tested the hypotheses that (i) stand fine root biomass increases with increasing tree species diversity and (ii) that 'overyielding' of species-rich stands in terms of fine root biomass is the consequence of spatial niche separation of different species in the soil.

In Chapter 3, we discussed the hypotheses that (iii) species mixtures result in a spatial segregation of the fine root systems of different species and (iv) that fine roots of tree saplings contribute significantly to total fine root biomass in stands with abundant offspring.

In Chapter 4, we tested the hypotheses that (v) seasonal changes in fine root mass are more pronounced in tree species-poor than in tree species-rich stands as a consequence of non-synchronous root mass peaks of the different tree species during the growing season, and that (vi) productivity and resilience of the fine root system (i.e. recovery after disturbance) increase with increasing tree species diversity. 


\subsection{References}

Assmann E (1970) The principles of forest yield study. Pergamon Press, Oxford

Bauhus J, Khanna PK, Menden N (2000) Aboveground and belowground interactions in mixed plantations of Eucalyptus globulus and Acacia mearnsii. Canadian Journal of Forest Research 30:1886-1894

Berish CW, Ewel JJ (1988) Root development in simple and complex tropical successional ecosystems. Plant and Soil 106:73-84

Bolte A, Villanueva I (2006) Interspecific competition impacts on the morphology and distribution of fine roots in European beech (Fagus sylvatica L.) and Norway spruce (Picea abies (L.) Karst.). European Journal of Forest Research 125:15-26

Brown AFH (1992) Functioning of mixed-species stands at Gisburn, N.W. England. In: Cannell MGR, Malcolm DC, Robertson PA (eds) The Ecology of Mixed-Species Stands of Trees. Blackwell, Oxford, pp 125-150

Brunner I, Godbold DL (2007) Tree roots in a changing world. Journal of Forest Research $12: 78-82$

Büttner V, Leuschner C (1994) Spatial and temporal patterns of fine root abundance in a mixed oak-beech forest. Forest Ecology and Management 70:11-21

Casper BB, Jackson RB (1997) Plant competition underground. Annual Review of Ecology and Systematics 28:545-570

Chapin FS, Walker BH, Hobbs RJ, Hooper DU, Lawton JH, Sala OE, Tilman D (1997) Biotic control over the functioning of ecosystems. Science 277:500-504

Chapin FS, Zavaleta ES, Eviner VT, Naylor RL, Vitousek PM, Reynolds HL, Hooper DU, Lavorel S, Sala OE, Hobbie SE, Mack MC, Diaz S (2000) Consequences of changing biodiversity. Nature 405:234-242

Chen HYH, Klinka K (2003) Aboveground productivity of western hemlock and western redcedar mixed-species stands in southern coastal British Columbia. Forest Ecology and Management 184:55-64

Cuevas E, Brown S, Lugo AE (1991) Aboveground and belowground organic-matter storage and production in a tropical pine plantation and a paired broadleaf secondary forest. Plant and Soil 135:257-268

Ehrlicher PR, Ehrlicher AH (1981) Extinction: the causes and consequences of the disappearance of species. Random House, New York

Elmqvist T, Folke C, Nystrom M, Peterson G, Bengtsson J, Walker B, Norberg J (2003) Response diversity, ecosystem change, and resilience. Frontiers in Ecology and the Environment 1:488-494 
Enquist BJ, Niklas KJ (2001) Invariant scaling relations across tree-dominated communities. Nature 410:655-660

Erskine PD, Lamb D, Bristow M (2006) Tree species diversity and ecosystem function: Can tropical multi-species plantations generate greater productivity? Forest Ecology and Management 233:205-210

Fogel R, Hunt G (1983) Contribution of mycorrhizae and soil fungi to nutrient cycling in a Douglas-fir ecosystem. Canadian Journal of Forest Research 13:219-232

Gamfeldt L, Hillebrand H, Jonsson PR (2008) Multiple functions increase the importance of biodiversity for overall ecosystem functioning. Ecology 89:1223-1231

Gastine A, Scherer-Lorenzen M, Leadley PW (2003) No consistent effects of plant diversity on root biomass, soil biota and soil abiotic conditions in temperate grassland communities. Applied Soil Ecology 24:101-111

Gaston KJ, Spicer JI (2002) Biodiversity - An Introduction. Blackwell Science, Oxford

Hector A, Schmid B, Beierkuhnlein C, Caldeira MC, Diemer M, Dimitrakopoulos PG, Finn JA, Freitas H, Giller PS, Good J, Harris R, Högberg P, Huss-Danell K, Joshi J, Jumpponen A, Körner C, Leadley PW, Loreau M, Minns A, Mulder CPH, O'Donovan G, Otway SJ, Pereira JS, Prinz A, Read DJ, Scherer-Lorenzen M, Schulze ED, Siamantziouras ASD, Spehn EM, Terry AC, Troumbis AY, Woodward FI, Yachi S, Lawton JH (1999) Plant diversity and productivity experiments in European grasslands. Science 286:1123-1127

Hector A (2001) Biodiversity and functioning of grassland ecosystems: Multi-site comparison. In: Kinzig AP, Tilman D, Pacala SW (eds) The Functional Consequences of Biodiversity: Empirical Progress and Theoretical Extensions. vol 33. Princton University Press, Princeton, pp 71-95

Hendriks CMA, Bianchi FJJA (1995) Root density and root biomass in pure and mixed forest stands of Douglas-fir and beech. Netherlands Journal of Agricultural Science 43:321-331

Hertel D (1999) Das Feinwurzelsystem von Rein- und Mischbeständen der Rotbuche: Struktur, Dynamik und interspezifische Konkurrenz. Dissertationes Botanicae 317. Gebrüder Borntraeger, Berlin, Stuttgart

Hölscher D, Hertel D, Leuschner C, Hottkowitz M (2002) Tree species diversity and soil patchiness in a temperate broad-leaved forest with limited rooting space. Flora 197:118-125

Hooper DU, Chapin FS, Ewel JJ, Hector A, Inchausti P, Lavorel S, Lawton JH, Lodge DM, Loreau M, Naeem S, Schmid B, Setala H, Symstad AJ, Vandermeer J, Wardle DA (2005) Effects of biodiversity on ecosystem functioning: A consensus of current knowledge. Ecological Monographs 75:3-35

Hooper DU, Vitousek PM (1997) The effects of plant composition and diversity on ecosystem processes. Science 277:1302-1305 
Jactel H, Brockerhoff E, Duelli P (2005) A test of the biodiversity-stability theory: metaanalysis of tree species diversity effects on insect pest infestations, and reexamination of responsible factors. In: Scherer-Lorenzen M, Körner C, Schulze ED (eds) Forest Diversity and Function. Temperate and Boreal Systems, vol 176. Springer, Berlin, pp 235-262

Johnson KH, Vogt KA, Clark HJ, Schmitz OJ, Vogt DJ (1996) Biodiversity and the productivity and stability of ecosystems. Trends in Ecology \& Evolution 11:372377

Jolliffe PA (1997) Are mixed populations of plant species more productive than pure stands? Oikos 80:595-602

Kelty MJ (1992) Comparative productivity of monocultures and mixed stands. In: Kelty MJ, Larson BC, Oliver CD (eds) The ecology and silviculture of mixed-species forests. Kluwer, Dordrecht, pp 125-141

Knoke T, Ammer C, Stimm B, Mosandl R (2008) Admixing broadleaved to coniferous tree species: a review on yield, ecological stability and economics. European Journal of Forest Research 127:89-101

Korn S (2004) Experimentelle Untersuchung der Wasseraufnahme und der hydraulischen Eigenschaften des Wurzelsystems von sechs heimischen Baumarten. PhD thesis. University of Goettingen. http://webdoc.sub.gwdg.de/diss/2004/korn

Légaré S, Bergeron Y, Pare D (2005) Effect of aspen (Populus tremuloides) as a companion species on the growth of black spruce (Picea mariana) in the southwestern boreal forest of Quebec. Forest Ecology and Management 208:211222

Leuschner C, Hertel D, Coners H, Büttner V (2001) Root competition between beech and oak: a hypothesis. Oecologia 126:276-284

Leuschner C, Jungkunst HF, Fleck S (2008) Functional role of forest diversity: Pros and cons of synthetic stands and across-site comparisons in established forests. Basic and Applied Ecology. In press

Lindén M, Agestam E (2003) Increment and yield in mixed and monoculture stands of Pinus sylvestris and Picea abies based on an experiment in southern Sweden. Scandinavian Journal of Forest Research 18:155-162

Loreau M (2000) Biodiversity and ecosystem functioning: recent theoretical advances. Oikos 91:3-17

Morgan JL, Campbell JM, Malcolm DC (1992) Nitrogen relations of mixed-species stands on oligotrophic soils. In: Cannell MGR, Malcolm DC, Robertson PA (eds) The ecology of mixed-species stands of trees. Blackwell, London, pp 65-85

Naeem S, Thompson LJ, Lawler SP, Lawton JH, Woodfin RM (1994) Declining biodiversity can alter the performance of ecosystems. Nature 368:734-737

Parrish JAD, Bazzaz FA (1976) Underground niche separation in successional plants. Ecology 57:1281-1288 
Peterson G, Allen CR, Holling CS (1998) Ecological resilience, biodiversity, and scale. Ecosystems 1:6-18

Pretzsch H (2005) Diversity and productivity in forests: evidence from long-term experimental plots. In: Scherer-Lorenzen M, Körner C, Schulze ED (eds) Forest Diversity and Function: Temperate and Boreal Systems, Ecological Studies, vol 176. Springer, Berlin, pp 41-64

Scherer-Lorenzen M (1999) Effects of plant diversity on exosystem processes in experimental grassland communities. Bayreuther Forum Ökologie 75:1-195

Scherer-Lorenzen M, Potvin C, Koricheva J, Schmid B, Hector A, Bornik Z, Reynolds G, Schulze ED (2005) The design of experimental tree plantations for functional biodiversity research. In: Scherer-Lorenzen M, Körner C, Schulze ED (eds) Forest Diversity and Function. Temperate and Boreal Systems, vol 176. Springer-Verlag, Berlin, pp 347-376

Schmid B, Joshi J, Schläpfer F (2001) Empirical evidence for biodiversity-ecosystem functioning relationships. In: Kinzig AP, Pacala SW, Tilman D (eds) The Functional Consequences of Biodiversity: Empirical Progress and Theoretical Extensions., vol 33. Princton University Press, Princton, pp 120-150

Schmid I (2002) The influence of soil type and interspecific competition on the fine root system of Norway spruce and European beech. Basic and Applied Ecology 3:339346

Schmid I, Kazda M (2002) Root distribution of Norway spruce in monospecific and mixed stands on different soils. Forest Ecology and Management 159:37-47

Schober R (1995) Ertragstafeln wichtiger Baumarten bei verschiedener Durchforstung. Sauerländer, Frankfurt/Main

Smith FW, Long JN (1992) A comparison of stemwood production in monocultures and mixtures of Pinus contorta var. latifolia and Abies lasiocarpa. In: Cannell MGR, Malcolm DC, Robertson PA (eds) The ecology of mixed-species stands of trees. Blackwell, London, pp 87-98

Spehn EM, Joshi J, Schmid B, Diemer M, Körner C (2000) Above-ground resource use increases with plant species richness in experimental grassland ecosystems. Functional Ecology 14:326-337

Szwagrzyk J, Gazda A (2007) Above-ground standing biomass and tree species diversity in natural stands of Central Europe. Journal of Vegetation Science 18:555-562

Tilman D, Downing JA (1994) Biodiversity and stability in grasslands. Nature 367:363365

Tilman D, Wedin D, Knops J (1996) Productivity and sustainability influenced by biodiversity in grassland ecosystems. Nature 379:718-720

Vilà M, Vayreda J, Gracia C, Ibanez JJ (2003) Does tree diversity increase wood production in pine forests? Oecologia 135:299-303 
Vogt KA, Vogt DJ, Palmiotto PA, Boon P, Ohara J, Asbjornsen H (1996) Review of root dynamics in forest ecosystems grouped by climate, climatic forest type and species. Plant and Soil 187:159-219

Walker BH (1992) Biodiversity and ecological redundancy. Conservation Biology 6:18-23

Wiedemann E (1949) Ertragstafeln der wichtigen Holzarten bei verschiedener Durchforstung. Schaper, Hannover

Yanai RD (1992) Competitive interactions between Norway spruce and Scots pine at Gisburn Forest, Nw England. Forestry 65:435-451 
CHAPTER

Fine root biomass and morphology in temperate broad-leaved forests differing in tree species diversity - is there evidence of overyielding? 


\subsection{Abstract}

Biodiversity effects on ecosystem functioning in forests have attracted increasing attention only recently. The vast majority of studies in forests have focussed on above-ground responses to differences in tree species diversity, while systematic analyses of the effects of biodiversity on root systems are virtually non-existent. By investigating the fine root systems in 12 temperate deciduous forest stands in Central Europe, we tested the hypotheses that (i) stand fine root biomass increases with tree diversity, and (ii) 'overyielding' of species-rich stands in terms of fine root biomass is the consequence of spatial niche segregation of the roots of different species. The selected stands represent a gradient in tree species diversity on similar bedrock from almost pure beech forests to medium-diverse forests built by beech, ash, and lime, and to highly-diverse stands dominated by beech, ash, lime, maple, and hornbeam. We investigated fine root biomass and necromass at 24 profiles per stand and analysed species differences in fine root morphology by microscopic analysis.

Fine root biomass ranged from 440 to $480 \mathrm{~g} \mathrm{~m}^{-2}$ in the species-poor to species-rich stands, with $63-77 \%$ being concentrated in the upper $20 \mathrm{~cm}$ of the soil. In contradiction to our two hypotheses, the differences in tree species diversity affected neither stand fine root biomass nor vertical root distribution patterns. Fine root morphology showed marked distinctions between species, but these root morphological differences did not lead to significant differences in fine root surface area or root tip number on a stand area basis. Moreover, differences in species composition of the stands did not alter fine root morphology of the species.

We conclude that 'overyielding' in terms of fine root biomass does not occur in the speciesrich stands, which is most likely caused by the absence of significant spatial segregation of the root systems of these late-successional species. 


\subsection{Introduction}

The majority of studies investigating the biodiversity-function relationship in grasslands found an increase in above-ground productivity with plant species diversity or diversity of plant functional types (e.g Tilman et al. 1996, Hooper \& Vitousek 1997, Hector 2001, Hector et al. 1999, Schmid et al. 2001). One explanation of 'overyielding' of species-rich stands is a more pronounced niche complementarity as compared to species-poor communities or even monocultures (Parrish \& Bazzaz 1976, Hector et al. 1999, Hector 2001). While the vast majority of studies on diversity effects on productivity were carried out in grasslands or other herbaceous communities (Tilman et al. 1996, Hooper \& Vitousek 1997, Hector et al. 1999, Joshi et al. 2000, Spehn et al. 2000, Loreau \& Hector 2001), the functional role of tree species diversity has only recently been investigated in more detail. The few studies investigating tree species diversity effects showed contradictory results (Pretzsch 2005). Some authors report overyielding effects in mixed compared to single tree species communities (e.g. Brown 1992, Morgan et al. 1992, Bauhus et al. 2000, Erskine et al. 2006), while others found no effect of tree species diversity on biomass accumulation and productivity or even negative effects (Smith \& Long 1992, Yanai 1992, Enquist \& Niklas 2001, Vilà et al. 2003, Szwagrzyk \& Gazda 2007). Most of these studies compared monocultures with two-species mixtures. The recently established tree plantations with stands differing in tree species diversity are in most cases too young to allow for sound conclusions on the diversity - productivity relationship (Scherer-Lorenzen et al. 2005).

In addition, the majority of the cited investigations have focused on the above-ground responses alone. Thus, little is known about the effects of tree species diversity on structure and function of the below-ground organs of trees. This is particularly unsatisfactory since the fine root system of trees is a functionally highly important compartment of forest ecosystems (e.g. DeAngelis et al. 1981, Fitter 1996). Fine roots are not only responsible for water and nutrient uptake, but also represent an important component of the ecosystem carbon cycle (Keyes \& Grier 1981, Fogel \& Hunt 1983, Jackson et al. 1997, Schlesinger 1997). One reason for the obvious lack of studies on the relationship between tree species diversity and root system structure and dynamics is the difficulty of distinguishing between the fine roots of different species. In fact, we know of only one study that investigated the structure of the fine root systems of more than two tree species in temperate deciduous forests, based on a determination key for identifying the fine roots of different species (Hölscher et al. 2002). The bulk of root studies in mixed forests referred to two-species 
stands and searched for biomass differences as compared to monospecific stands and for hints of vertical root stratification among species as an effect of root competition (Morgan et al. 1992, Hertel 1999, Schmid 2002). In several cases, a higher total fine root biomass in mixed compared to monospecific stands was found (Berish \& Ewel 1988, Cuevas et al. 1991, Schmid \& Kazda 2002), while other studies found fine root biomass to be unaffected by the presence of an allospecific below-ground competitor (Bauhus et al. 2000, Leuschner et al. 2001). However, trees could not only respond to the presence of one (or more) competing tree species by changes in fine root biomass and its spatial distribution, but also with modification of fine root morphological traits such as specific root area (SRA) or branching patterns. For example, studies of Lohmus et al. (1989) and Ostonen et al. (2007) showed that fine root morphology can be highly plastic in response to different nutrient availabilities. Whether the fine root morphology of trees responds to the presence of roots of other tree species is not yet clear.

This study investigated structural properties of the fine root system of deciduous forests with low, modest and high tree species diversity, which grow in close neighbourhood to each other under similar edaphic and climatic conditions. Based on previous work, we were able to identify tree fine roots by species and thus analyse the exploration of the below-ground environment by different tree species quantitatively. We tested the hypotheses that (i) stand fine root biomass increases with increasing tree species diversity, and (ii) 'overyielding' of species-rich stands in terms of fine root biomass is the consequence of spatial niche separation of different species in the soil. Study objectives were (a) to quantify stand fine root biomass in 12 forest stands with either 1,3 or 5 dominant tree species, (b) to analyse the contribution of the different tree species to total fine root biomass and to search for species differences in root:shoot ratios, (c) to assess the evidence for spatial niche differentiation below-ground, and (d) to quantify differences in fine root morphological traits between the species and to study possible differences might be caused by different levels of tree species diversity. 


\subsection{Materials and methods}

\section{Study site}

The study was conducted in a species-rich deciduous forest in the Hainich National Park, Thuringia, Germany. This National Park is characterised by one of the largest continuous forest covers in Europe. It contains areas of different levels of tree species diversity due to differences in forest management strategies in past centuries. We selected 12 study plots (50 $\mathrm{m} \times 50 \mathrm{~m}$ each) in the north-east of the National Park representing three tree diversity levels (DL 1, DL 2, and DL 3) with each 4 replicates per diversity level. Plots of diversity level 1 were dominated with a minimum of $95 \%$ of the total basal area by Fagus sylvatica L. DL 2 plots were characterised by Fagus s. (mean of $60 \%$ of total basal area), Tilia species (T. cordata Mill. and/or T. platyphyllos Scop., 6 \%) and Fraxinus excelsior L (22 $\%)$. DL 3 plots included five main tree species: Fagus s. (19\%), Tilia species (18\%), Fraxinus e. (18\%), Carpinus betulus L. (12\%) and Acer species (A. pseudoplatanus L. and/or A. platanoides L., $4 \%$ ). Other tree species, e.g. Quercus robur, Q. petraea, Prunus avium and Ulmus glabra are found occasionally in some of the DL 3 plots. A herb layer with a cover of $24 \%$ to $91 \%$ of the ground area was present at the study plots. In all stands, mean tree age ranged from 80 to 140 years except for stand DL 1c, where the beech trees were c. 180 years old. All stands had a closed canopy and similar basal areas (32 to $46 \mathrm{~m}^{2} \mathrm{ha}^{-1}$ ) (Table 2.1). Detailed information on the criteria of plot selection is given in Leuschner et al. (2008). All plots are located at an elevation of $350 \mathrm{~m}$ a.s.l. The mean annual temperature is $7.5{ }^{\circ} \mathrm{C}$ and annual precipitation is $670 \mathrm{~mm}$ (data of the nearby weather station Weberstedt/Hainich). The soils in the study area all developed from a similar substrate consisting of a loess cover with a minimum of $60 \mathrm{~cm}$ depth over Triassic limestone. The soil type was classified as Luvisol (FAO taxonomy, 2006) with stagnic properties in spring and winter and a dry period in summer. The soil texture of the mineral soil $(0-30 \mathrm{~cm})$ showed high silt $(\mathrm{c} .74 \%)$ and low sand $(<5 \%)$ contents (Guckland et al. 2008). In 0-10 cm depth, $\mathrm{pH}\left(\mathrm{H}_{2} \mathrm{O}\right)$ was about 6.0 or higher in the DL 2 and DL 3 plots, but tended to be lower in the beech-dominated DL 1 plots. As a consequence, base saturation ranged from 60 to $99 \%$ in the DL 2 and DL 3 plots, but was lower in the DL 1 plots. 
Table 2.1 Characteristics of above-ground stand structure and soil chemical parameters of the 12 study plots in the diversity levels 1 to 3 . Data on basal area, stem density, mean tree height of canopy trees and canopy cover were provided by Brauns (unpublished), mean tree age of canopy trees by Schmidt (unpublished), herb cover and $\mathrm{pH}$-values by Mölder et al. (2006) and Mölder et al. (2008), C/N ratio and base saturation by Guckland et al. (2008).

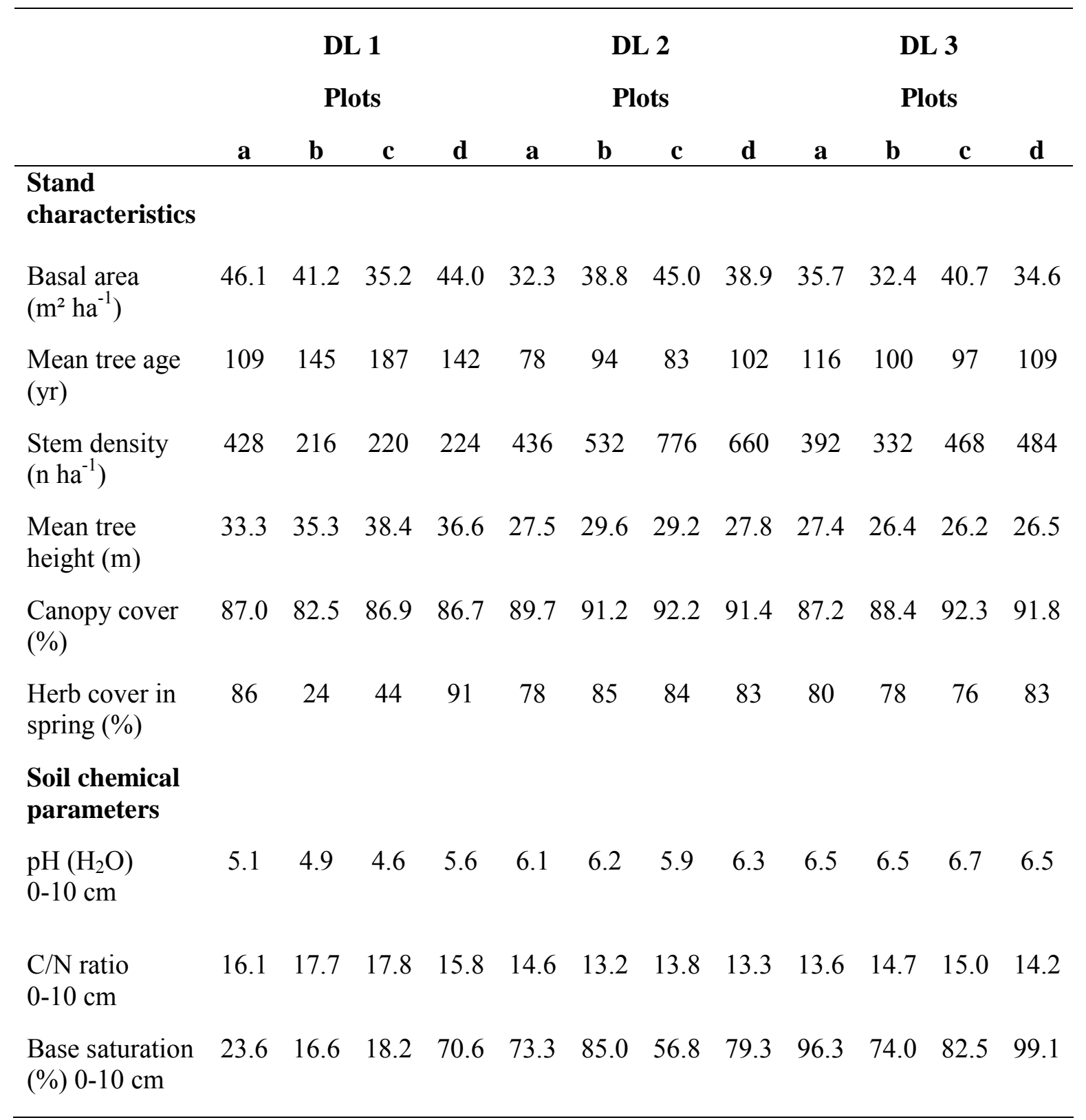




\section{Soil sampling and root analysis}

Each 24 sampling locations were selected by random in the 12 study plots. Minimum distance between sampling locations was $1 \mathrm{~m}$. Soil samples were taken at each location in 2005 and 2006 with a soil corer of $3.5 \mathrm{~cm}$ in diameter down to $40 \mathrm{~cm}$ soil depth and also included the organic layer. The cores were divided into 4 sub-samples of $10 \mathrm{~cm}$ length each. The samples were stored in plastic bags at $5{ }^{\circ} \mathrm{C}$ and processed within 6 weeks. To analyse the fine root (diameter $\leq 2 \mathrm{~mm}$ ) mass, the samples were soaked in water and cleaned from soil residues using a sieve (mesh size $0.25 \mathrm{~mm}$ ). Fine root fragments longer than $1 \mathrm{~cm}$ were collected by hand with a pair of tweezers and separated under a stereomicroscope into live and dead fractions and sorted by species. For separating live and the dead fraction, morphological criteria such as root elasticity, the degree of cohesion of root stele and periderm, and the presence or absence of the stele were used (Persson 1978, Leuschner et al. 2001). For species identification, a classification system based on morphological attributes, such as surface structure and colour of the periderm, ramification pattern and type of mycorrhizal infection was used (partly published in Hölscher et al. 2002). Herb and grass roots were distinguished from tree roots by their lack of visible suberinization, their lighter colour and their smaller diameter. Because the root biomass of the herbaceous plant community was small and varied with season, this root mass fraction was investigated only for the plots DL 1a, DL 2c and DL 3a in April 2006, June 2006, September 2006 and January 2007. The fraction of tree fine roots $\geq 1 \mathrm{~cm}$ length represent the major part of the living fine root mass, while a large part of the dead fine root mass consists of root fragments smaller than 1cm length (Bauhus \& Bartsch 1996, Hertel 1999). To record this fraction of dead rootlets, a method introduced by van Praag et al. (1988) and modified by Hertel (1999) was applied to one sixth of all samples. After extraction of the root fragments $>1 \mathrm{~cm}$ from these samples, the soil residues were evenly distributed on a large sheet of filter paper $\left(730 \mathrm{~cm}^{2}\right)$ subdivided into 36 squares. Six of the squares were randomly selected and all dead root material was collected under a stereomicroscope. A regression between the dead roots fraction $<1 \mathrm{~cm}$ and the dead roots fraction $>1 \mathrm{~cm}$ was calculated from these samples to extrapolate the total dead fine root mass of all samples. Fine root biomass and fine root necromass of all samples were dried at $70{ }^{\circ} \mathrm{C}$ for $48 \mathrm{~h}$ and weighed. Fine root biomass and necromass were calculated for each sample as dry matter per square meter ground area $\left(\mathrm{g} \mathrm{m}^{-2}\right)$ for each soil depth and as soil profile total. To cover the fine root mass present below $40 \mathrm{~cm}$ soil depth, a non-linear vertical distribution model 
introduced by Gale \& Grigal (1987) was applied to the fine root data from 0-40 cm soil depth. One living root branch per species of each sample and soil depth was scanned for analysis of root surface area and mean root diameter. Digital images were analysed with the computer software WinRhizo 2002a (Régent, Quebec, Canada). Specific fine root surface area (SRA, $\mathrm{cm}^{2} \mathrm{~g}^{-1}$ ) was calculated from dry weight of the respective root branch and its surface area. Root area index (RAI, square meter root surface area per square meter ground area) was calculated from fine root biomass and specific fine root surface area of the respective species. In addition, the number of root tips was counted under the stereomicroscope. This data was used to calculate specific root tip abundance (number of tips per mg dry weight and number of root tips per square meter stand area, respectively).

\section{Statistical analyses}

All data were tested for Gaussian distribution using a Shapiro-Wilk test. The majority of the datasets showed a non-gaussian distribution and could not satisfyingly be transformed. Therefore, a non-parametric U-test of Mann and Whitney was used to detect significant differences between different samples $(\mathrm{p}<0.05)$. This test was carried out with the software package SAS, version 8.2 (SAS Institute Inc., Cary, NC, USA). The linear regression fits and the non-linear cumulative root distribution model after Gale \& Grigal (1987) were computed with the software package Xact (version 8.03, SciLab, Hamburg, Germany).

\section{$2.4 \quad$ Results}

\section{Living and dead fine root mass}

Total fine root biomass showed no significant differences between the almost pure beech plots (DL 1) and the plots dominated by three (DL 2) or five tree species (DL 3) (Figure 2.1a). In all plots, fine root biomass decreased markedly with soil depth with 64-77\% being located in the upper $20 \mathrm{~cm}$ of the soil. Fine root necromass also did not differ significantly between the three diversity levels, but DL 3 plots tended to hold less fine root necromass than DL 2 and DL 1 plots (Figure 2.1b). The bulk of fine root necromass also was found in the upper $20 \mathrm{~cm}$ of the soil (72-79\%). 

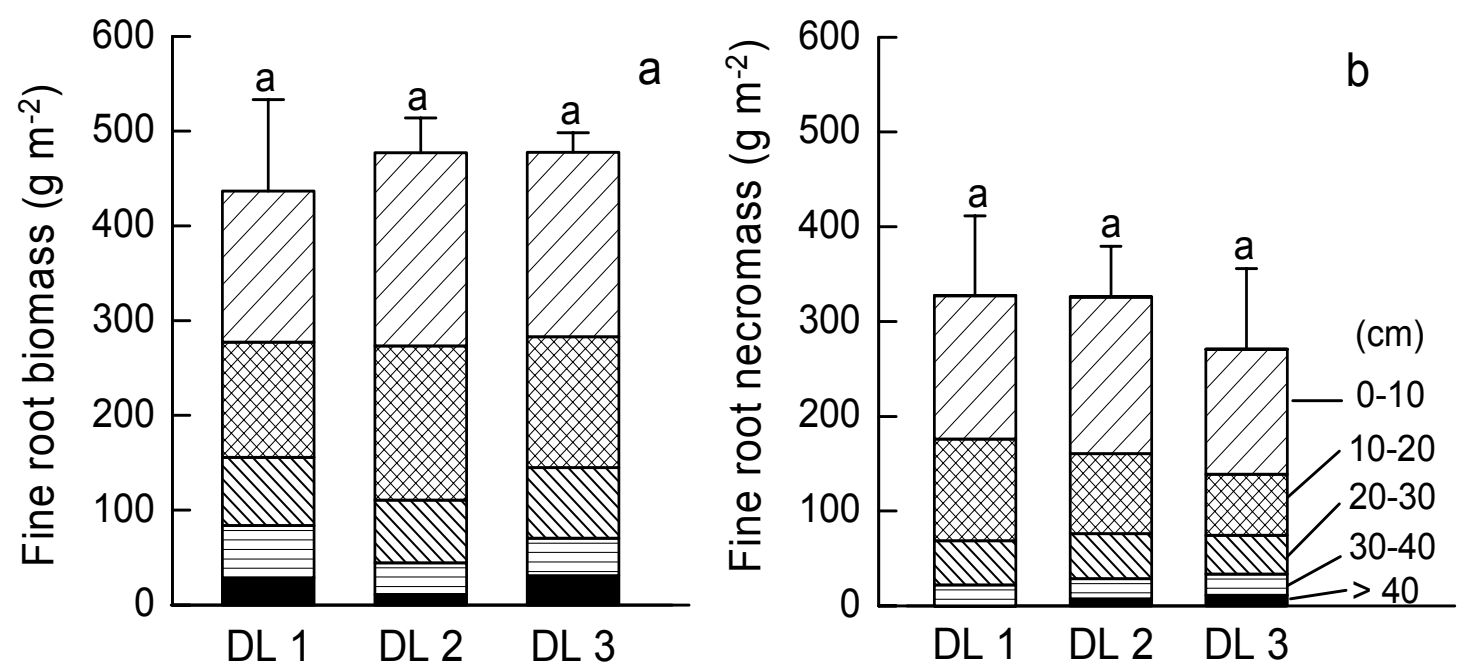

Figure 2.1 Fine root biomass (a) and fine root necromass (b) in different soil layers of forest plots of three diversity levels (DL). Given are means \pm 1 SE from each 4 replicate plots per diversity level ( $\mathrm{n}=24$ sampling locations per plot). Different letters indicate significant differences between diversity levels; $p<0.05$. The fine root biomass below 40 $\mathrm{cm}$ soil depth was estimated with the depth distribution equation for roots of Gale \& Grigal (1987) parameterized for the tree species of this study.

The contribution of root biomass of herbaceous plants to the fine root mass totals of the plots was only marginal. In the DL 1 a plot, only $1 \%$ of the fine root biomass total originated from herbs (Table 2.2). The plots with highest tree species richness (DL 3a) showed a significantly higher herb fine root biomass than the DL 1a and DL 2c plots. However, despite a herb cover of $80 \%$ in DL 3 , only $4 \%$ of the total fine root mass belonged to herbs.

Table 2.2 Mean root biomass of herbaceous plants in the soil profile $(0-40 \mathrm{~cm})$ in the plots DL 1a, DL 2c and DL 3a (absolute values: $\mathrm{g} \mathrm{m}^{-2}$, relative values in $\%$ of tree and herb fine root total in the profile. Given are means $\pm 1 \mathrm{SE}(\mathrm{n}=4)$ from sampling campaigns in April 2006, June 2006, September 2006 and January 2007. Different letters indicate significant differences between the three plots; $p<0.05$.

\section{Plots}

DL 1a DL 2c DL 3a

Herb fine root biomass $\left(\mathrm{g} \mathrm{m}^{-2}\right)$

Contribution to total stand of fine root biomass $(\%)$
$4.3 \pm 1.3 \mathrm{a}$
$5.3 \pm 0.6 \mathrm{a}$
$19.2 \pm 2.0 \mathrm{~b}$

1.0

1.1

3.9 
Regression analysis showed that total fine root biomass (0-40 $\mathrm{cm}$ soil depth) was positively related to the number of tree species present. In addition, fine root biomass in the upper 10 $\mathrm{cm}$ of the soil positively correlated with the base saturation and the $\mathrm{pH}\left(\mathrm{H}_{2} \mathrm{O}\right)$ in this soil depth (Table 2.3). However, tree species diversity and soil chemistry explained only 22-32 $\%(r=0.47-0.57)$ of the variation. In contrast, fine root necromass was not significantly influenced by any of these parameters.

Table 2.3 Results of linear regression analyses relating stand structural and edaphic variables measured at the 12 plots to fine root biomass and fine root necromass.

\begin{tabular}{llll} 
Dependent variable & Source & $\mathbf{r}$ & $\mathbf{p}$ \\
\hline
\end{tabular}

Fine root biomass

at $0-40 \mathrm{~cm}$

at $0-10 \mathrm{~cm}$

at $0-10 \mathrm{~cm}$

Fine root necromass

at $0-40 \mathrm{~cm}$

at $0-10 \mathrm{~cm}$

at $0-10 \mathrm{~cm}$
Number of dominant tree species in the stand

Base saturation $(0-10 \mathrm{~cm})$

$\mathrm{pH}\left(\mathrm{H}_{2} \mathrm{O}\right)(0-10 \mathrm{~cm})$

$0.47<0.05$

$0.47<0.05$

$0.57<0.05$

$\begin{array}{lll}\text { Number of dominant tree species in the stand } & -0.07 & \text { n.s. } \\ \text { Base saturation }(0-10 \mathrm{~cm}) & -0.23 & \text { n.s. } \\ \text { pH }\left(\mathrm{H}_{2} \mathrm{O}\right)(0-10 \mathrm{~cm}) & -0.23 & \text { n.s. }\end{array}$

Although mean fine root biomass $(0-40 \mathrm{~cm})$ per ground area showed no significant differences between stands differing in tree diversity, fine root biomass in samples from the topsoil (0-10 cm depth) was significantly higher when four species were present in a soil sample as compared to less diverse samples (Figure 2.2). Soil samples with one, two or three root species present differed not significantly with respect to fine root biomass.

\section{Species contribution to stand fine root biomass}

As expected, stands with a higher tree species richness were more diverse below-ground (Figure 2.3). The proportion of Fagus fine roots of total fine root biomass decreased strongly from DL 1 to the DL 3 plots while that of Tilia, Fraxinus and Acer increased. In the DL 3 plots, fine roots of Fraxinus and Tilia were the most abundant species, followed by Acer, Carpinus, and Fagus. 


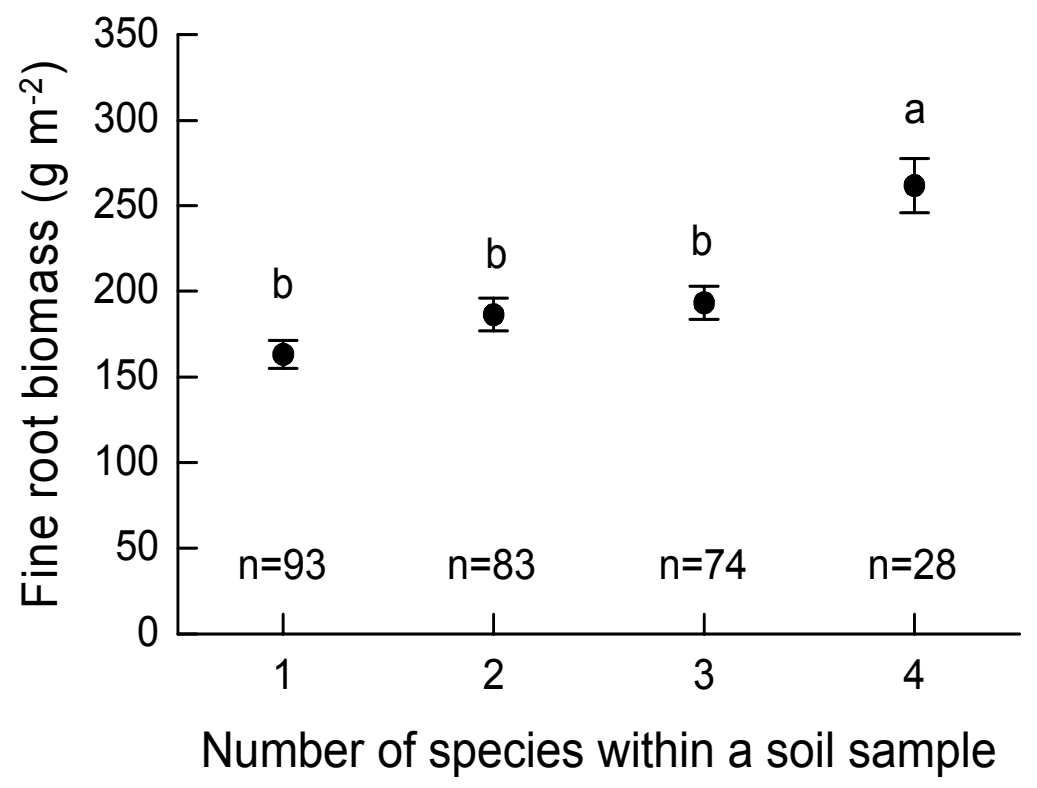

Figure 2.2 Fine root biomass in the upper soil $(0-10 \mathrm{~cm})$ as dependent on the number of tree species present in the soil samples of the 12 forest plots. Given are means $\pm 1 \mathrm{SE}$. Different letters indicate significant differences between the 4 classes; $p<0.05$.

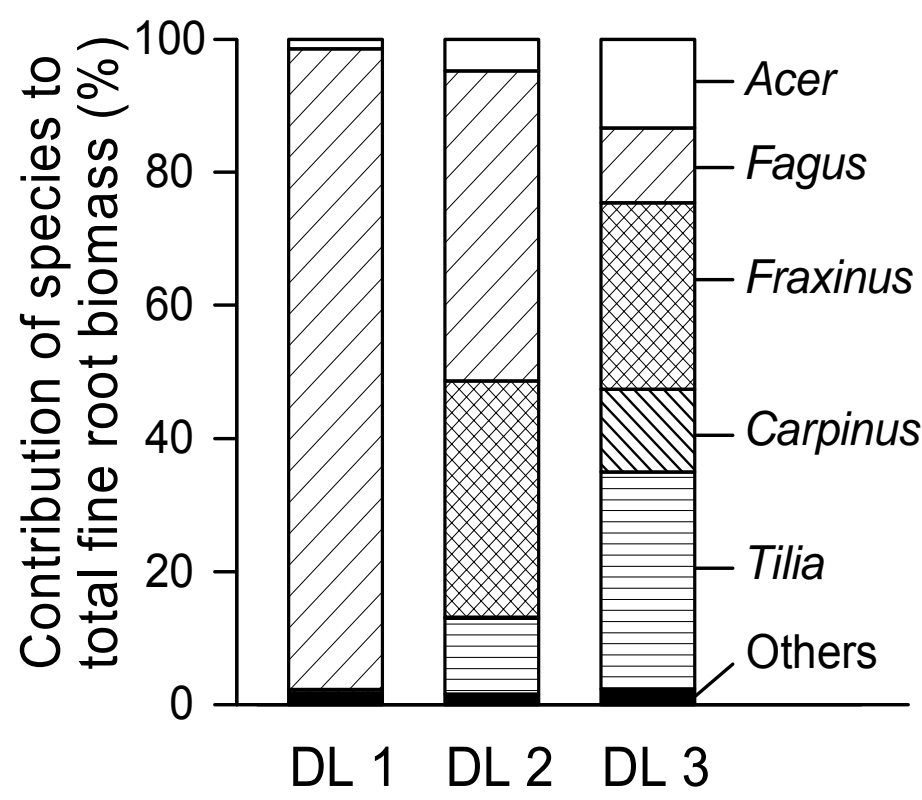

Figure 2.3 Contribution of the different tree species to the profile totals $(0-40 \mathrm{~cm})$ of fine root biomass in forest plots of the three diversity levels (DL). Given are the means of each 4 replicate plots and 24 sampling locations per plot. "Others" species refer to Acer campestre, Prunus avium, Ulmus glabra and Quercus sp. 
The comparison of the above-ground abundance of the species (expressed as a species contribution to total stand basal area) with their abundance in the root samples revealed unbalances. The ratio of percental fine root biomass to percental basal area was $>1$ for Fraxinus and Tilia in the DL 2 plots, thus indicating higher below-ground than aboveground abundances, whereas Fagus and Acer were underrepresented in the soil (Table 2.4). In the DL 3 plots, the highest relative below-ground abundance was found for Fraxinus and Acer. Tilia and Carpinus showed similar abundances above- and below-ground, while Fagus (and other, more rare species) was markedly more abundant above-ground than below-ground.

Table 2.4 Ratio of the percental contribution of a species in fine root biomass to its percental contribution to stand basal area and fine root biomass/necromass ratio in the plots of the three diversity levels $(n=4)$. Given are means \pm 1 SE. Fine root data refer to soil profile totals $(0-40 \mathrm{~cm}$ depth). Different letters indicate significant differences between species (Latin letters) or diversity levels (Greek letters); $p<0.05$. "Other species" refer to mean values of Prunus avium, Ulmus glabra and Quercus sp. present with low abundance in the stands.

\begin{tabular}{|c|c|c|c|c|c|c|}
\hline \multirow[b]{2}{*}{ Species } & \multicolumn{3}{|c|}{$\begin{array}{l}\text { Fine root biomass/basal area ratio } \\
\left.\text { (percent percent }{ }^{-1}\right)\end{array}$} & \multicolumn{3}{|c|}{$\begin{array}{l}\text { Fine root biomass/necromass ratio } \\
\qquad\left(\mathrm{g} \mathrm{g}^{-1}\right)\end{array}$} \\
\hline & DL 1 & DL 2 & DL 3 & DL 1 & DL 2 & DL 3 \\
\hline Fagus s. & $1.0 \pm 0.03 \alpha$ & $0.7 \pm 0.1 \mathrm{a} \beta$ & $0.6 \pm 0.2$ a $\beta$ & $1.6 \pm 0.3 \mathrm{a} \alpha$ & $1.8 \pm 0.2 \mathrm{a} \alpha$ & $2.6 \pm 0.9 \mathrm{a} \alpha$ \\
\hline Fraxinus e. & & $1.6 \pm 0.4 \mathrm{a} \alpha$ & $1.8 \pm 0.5 \mathrm{bc} \alpha$ & & $1.4 \pm 0.3 \mathrm{a} \alpha$ & $1.5 \pm 0.2 \mathrm{a} \alpha$ \\
\hline Tilia sp. & & $1.4 \pm 0.4 \mathrm{a} \alpha$ & $0.9 \pm 0.2 \mathrm{a} \alpha$ & & $1.7 \pm 0.5 \mathrm{a} \alpha$ & $2.4 \pm 0.4 \mathrm{a} \alpha$ \\
\hline Acer sp. & & $0.8 \pm 0.2 \mathrm{a} \alpha$ & $1.8 \pm 0.1 \mathrm{c} \beta$ & & $1.1 \pm 0.1 \mathrm{a} \alpha$ & $3.5 \pm 1.3 \mathrm{a} \alpha$ \\
\hline Carpinus $b$. & & & $1.1 \pm 0.2 \mathrm{abc}$ & & & $3.6 \pm 1.4 \mathrm{a} \alpha$ \\
\hline Other species & & & $0.5 \pm 0.3 \mathrm{ab}$ & & & $7.0 \pm 6.0 \mathrm{a} \alpha$ \\
\hline Stand total & - & - & - & $1.5 \pm 0.3 \mathrm{a} \alpha$ & $1.5 \pm 0.2 \mathrm{a} \alpha$ & $2.1 \pm 0.5$ a $\alpha$ \\
\hline
\end{tabular}

The ratio of living to dead fine roots was $>1$ in all stands and species and showed no significant differences between species or diversity levels (Table 2.4). However, there was a tendency for living Fagus fine roots to increase with increasing tree species diversity. All species tended to show highest live to dead root ratios in the most tree species-rich stands of DL 3. 


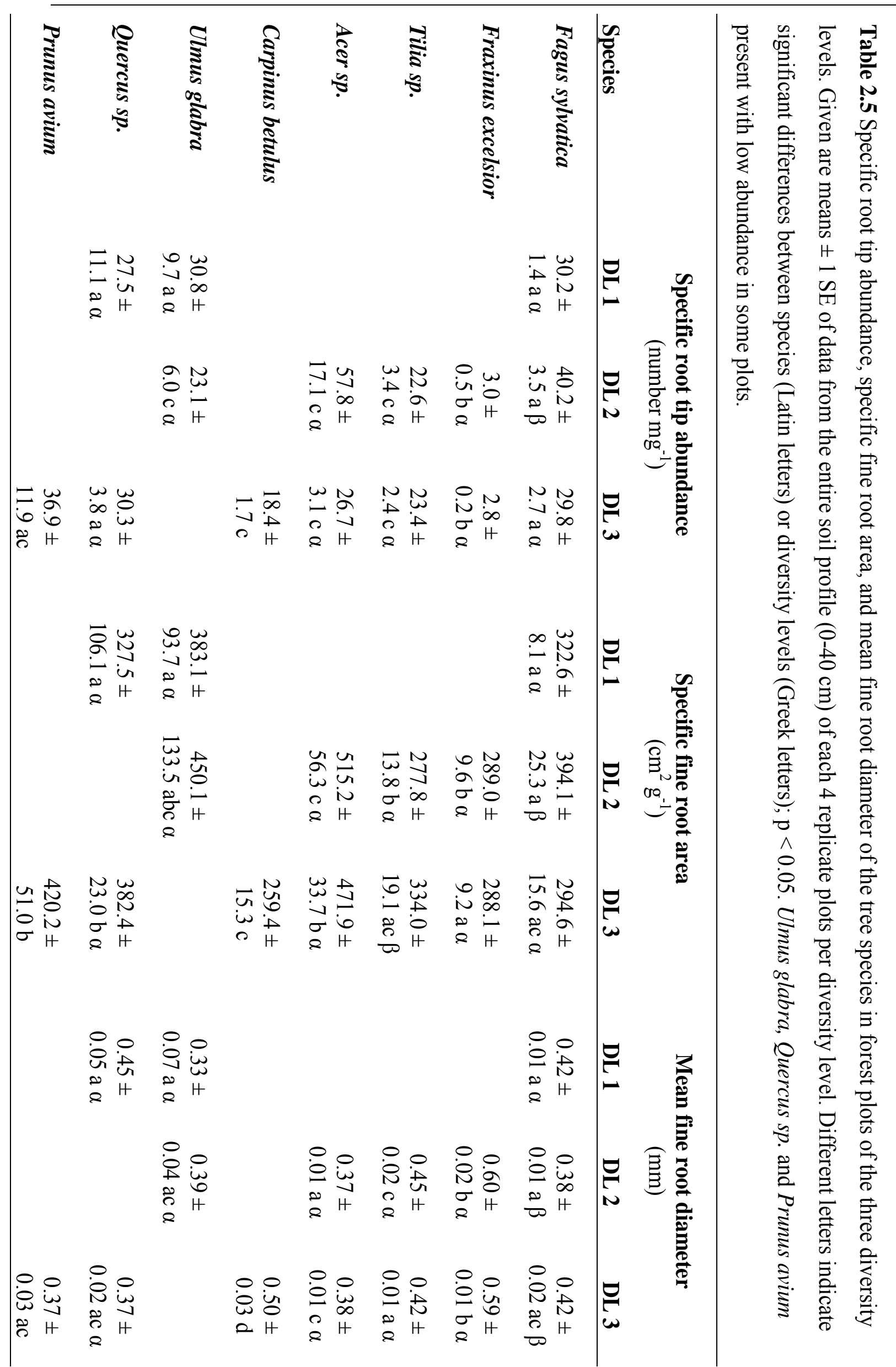




\section{Fine root morphology of the species}

Root morphological parameters differed significantly between species, but differences of a species between the three diversity levels were rarely found (Table 2.5). Specific root tip abundance was lowest (about 3 tips $\mathrm{mg}^{-1}$ ) in Fraxinus and ranged from 20 to $60 \mathrm{mg}^{-1}$ in the other species. Fagus showed a significantly higher specific root tip abundance in DL 2 compared to DL 1 and DL 3 plots. For most species, specific root area (SRA) values ranged from 280 to $400 \mathrm{~cm}^{2} \mathrm{~g}^{-1}$ with Acer reaching SRA values of 470 to $515 \mathrm{~cm}^{2} \mathrm{~g}^{-1}$. Fagus showed a significantly higher SRA in DL 2 plots compared to DL 1 and DL 3 plots, while SRA of Tilia were highest in the DL 3 plots. Mean fine root diameter in the class $<2$ $\mathrm{mm}$ ranged from $0.35 \mathrm{~mm}$ to $0.60 \mathrm{~mm}$ with highest values measured in Fraxinus. None of the three morphological parameters was significantly affected by tree species diversity, only root diameter of Fagus was smaller in the DL 2 than in the DL 1 and DL 3 plots.

\section{Number of root tips and root area index of the stands}

The total number of root tips per $\mathrm{m}^{2}$ ground area was similar in the DL 1 and DL 2 plots (about $1.2 \cdot 10^{7}$ tips $\mathrm{m}^{-2}$ ) (Figure $2.4 \mathrm{a}$ ), but as low as $0.8 \cdot 10^{7}$ tips $^{-2}$ in the DL 3 plots. Although Fraxinus and Tilia were co-dominant with Fagus in the DL 2 plots, root tips of Fagus represented the major part of total root tip number not only in DL 1, but also in the DL 2 plots. In DL 3 plots, root tips of Tilia were most abundant followed by those of Fagus, Acer and Carpinus. Root tips of Fraxinus accounted for only $4 \%$ of the total number of root tips in DL 3 stands.

Root area indices (RAI) ranged from 12 to $13 \mathrm{~m}^{2} \mathrm{~m}^{-2}$ (Figure 2.4b). Fagus and Fraxinus roots accounted for the major part (82\%) of total RAI in DL 2 plots. In DL 3 plots, Tilia and Fraxinus presented the highest proportion, $32 \%$ and $26 \%$, respectively, of RAI, followed by Acer (20\%), Fagus (11\%) and Carpinus (10\%). 

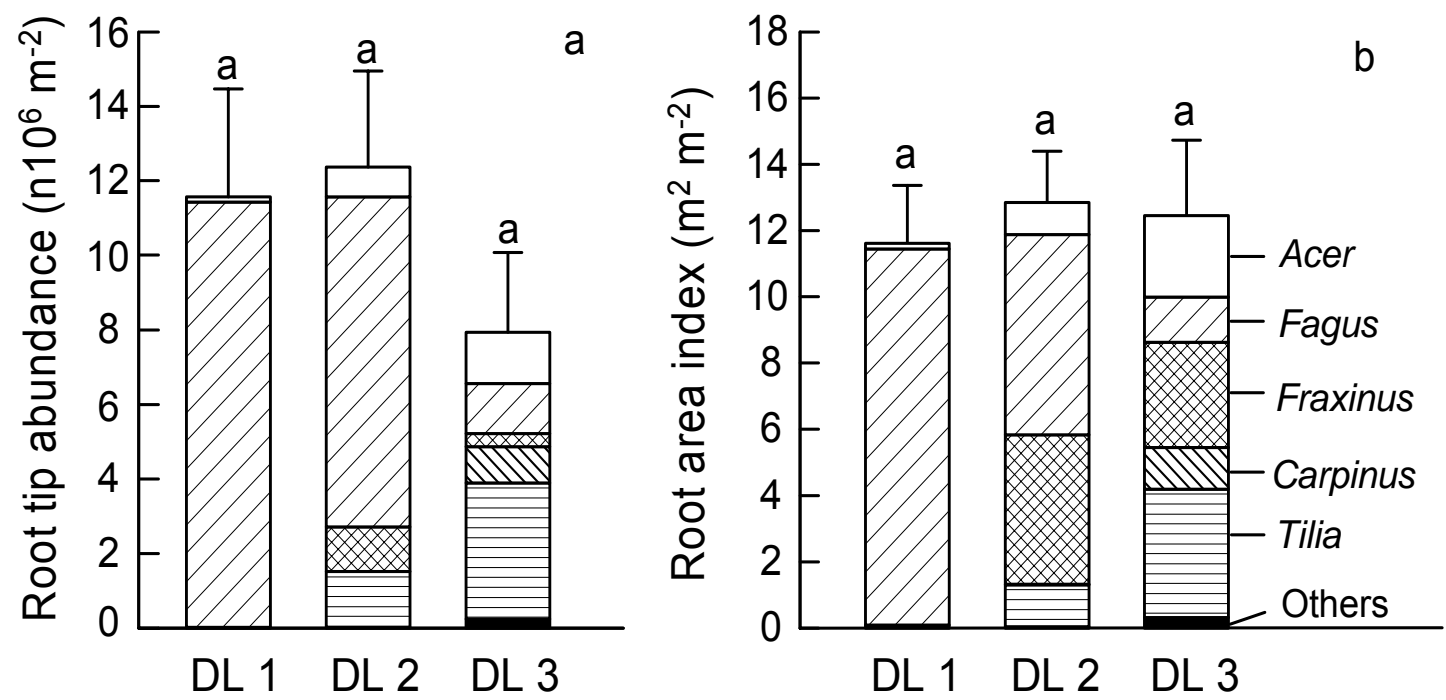

Figure 2.4 Root tip abundance (a) and root area index (b) in forest plots of the three diversity levels (DL). Given are means $\pm 1 \mathrm{SE}$ of each 4 replicate plots per diversity level ( $\mathrm{n}=24$ sampling locations per plot, soil depth 0-10 cm). Different letters indicate significant differences between diversity levels; $p<0.05$. "Others" species refer to Acer campestre, Prunus avium, Ulmus glabra and Quercus sp.

\subsection{Discussion}

Fine root biomass in stands with low and high species diversity

A main objective of our study was to test the hypothesis that species-rich mature forests exhibit higher fine root biomasses than species-poor stands has. 'Overyielding' in terms of fine root biomass in mixed forests could result from inherent differences in the species' rooting patterns which lead to a deeper extension or a higher density of the fine root system in mixed as compared to pure stands (Curt \& Prévosto 2003, Légaré et al. 2005, Jose et al. 2006). On the other hand, if root competition between different species would favour spatial niche differentiation between the root systems of the present species, adaptive growth processes could also result in a higher below-ground biomass following from the exploration of empty space in the rooting environment. Spatial compartmentalisation could reduce interspecific root competition and lead to complementary use of water and nutrients in the soil. Overyielding in terms of productivity or standing biomass has been proved for the above-ground compartments of certain forests (e.g. Morgan et al. 1992, Erskine et al. 2006). 
Moreover, biotic interactions between plants, animals, and micro-organisms that may facilitate the coexistence of plant species is expected to increase with increasing plant diversity (e.g. Blair et al. 1990, Quested et al. 2005).

In contradiction to our first hypothesis, fine root biomass of the 12 investigated forest stands did not differ significantly between plots dominated by five tree species, three species and almost pure beech forests. This finding is surprising since marked effects of increasing plant diversity on ecosystem functions are expected particularly in plant communities with relatively small numbers of species (Vitousek \& Hooper 1993, Jolliffe 1997). Analysis of the depth distribution patterns of the fine roots revealed that the vertical stratification of the fine root systems of the different species was very similar. All species showed a strong exponential decrease of fine root biomass with soil depth, with $63-77 \%$ of total fine root biomass being concentrated in the uppermost $20 \mathrm{~cm}$ of the soil irrespective of the species diversity in the stands. This was confirmed by applying a regression equation of the form $y=1-\beta^{\mathrm{d}}$ (Gale \& Grigal (1987) with $\mathrm{y}=$ cumulative fine root biomass fraction in $\mathrm{g} \mathrm{m}^{-2}$ and $\mathrm{d}=$ soil depth) to the fine root biomass data of the species present in the different stands. The similarity of the $\beta$ values (0.92-0.94 for Fagus in DL 1DL 3 plots, 0.92 for Fraxinus in DL 2-3 plots, 0.92-0.93 for Tilia in DL 2-3 plots, and 0.91-0.92 for Acer in DL 2-3 plots) indicate a rather superficial rooting pattern of all species (Meinen et al., submitted). Only Carpinus showed a somewhat less superficial fine root distribution in the DL 3 plots $(\beta=0.95)$. According to these results, a pronounced segregation of the fine root systems of the co-occurring tree species did not exist in the stands.

Avoidance of competition could be one cause of a vertical stratification of root systems in species-rich stands. By comparing monocultures and mixtures of the same two species, Schmid \& Kazda (2002) found different vertical fine root distributions in mono-specific and mixed spruce and beech stands and Hendriks \& Bianchi (1995) reported similar results for pure and mixed stands of Douglas fir and beech. For mixed stands of deciduous tree species, Büttner \& Leuschner (1994) also showed that the vertical rooting patterns of beech and oak differed between the species and that the cause was most likely asymmetric root competition (see also Hertel 1999 and Leuschner et al. 2001). Rust \& Savill (2000) obtained similar results for competing beech and ash. Hence, it is surprising that a corresponding vertical stratification of the fine root mass of the different species did not occur in the DL 2 and DL 3 stands of the Hainich forest. Assuming that below-ground competition is the cause of root system segregation, one may expect that competition 
intensity is less in soils with high nutrient availability as in the Hainich forest, thus reducing the benefit of avoiding competition through niche differentiation. A comparison of our results with available literature data shows that the fine root biomass records of 440$480 \mathrm{~g} \mathrm{~m}^{-2}$ in our study are well in accordance with the mean value of $440 \mathrm{~g} \mathrm{~m}^{-2}$ given for temperate deciduous forests in the meta-analysis of Jackson et al. (1996). However, this data set includes a broad range of different site conditions and does not differentiate between pure and mixed forests. For pure European beech forests on soils with high nutrient availability, results of Bauhus \& Bartsch (1996), Hertel (1999), Leuschner et al. (2004), and Bolte \& Villanueva (2006) reveal a mean value of fine root biomass (437 g $\mathrm{m}^{-2}$ ) very similar to the one measured in the monospecific beech stands in our study (see also reviewed data in Leuschner \& Hertel 2003). On the other hand, a compilation of literature data on fine root biomasses in species-rich temperate broad-leaved forests on soils with modest to high nutrient availability gave a mean value of c. $400 \mathrm{~g} \mathrm{~m}^{-2}$ which is lower than the $480 \mathrm{~g} \mathrm{~m}^{-2}$ in the mixed Hainich stands with three or five abundant species (Table 2.6). Certain mixed deciduous forests on rich soils in Central Europe revealed remarkably small fine root biomass values much lower than those in our study plots: Rewald \& Leuschner (submitted) found $180 \mathrm{~g} \mathrm{~m}^{-2}$ in a four-species oak-hornbeam forest, Andersson (1970) $172 \mathrm{~g} \mathrm{~m}^{-2}$ in a Quercus-Tilia forest, and Hölscher et al. (2002) reported of only $59 \mathrm{~g} \mathrm{~m}^{-2}$ in a forest of six species on a boulder slope. Compared to these data, fine root biomass and, hence, fine root densities in the mixed DL 2 and DL 3 plots were relatively high, thus indicating that interspecific below-ground competition should be intense in these stands. This is all the more plausible since the majority of soil samples from the Hainich forest contained fine roots of two or more tree species. We suggest that the clayey soil with a high resistance to root penetration may be one reason for the similar vertical root distribution patterns of the different tree species in the Hainich stands, making spatial root segregation difficult in these soils. This might explain that increasing tree species diversity from DL 1 to DL 3 stands did not lead to an increasing fine root biomass in the Hainich stands. Clearly, standing fine root biomass may be a poor indicator of fine root production which might be a more decisive parameter to be quantified for an assessment of below-ground 'overyielding' phenomena. 


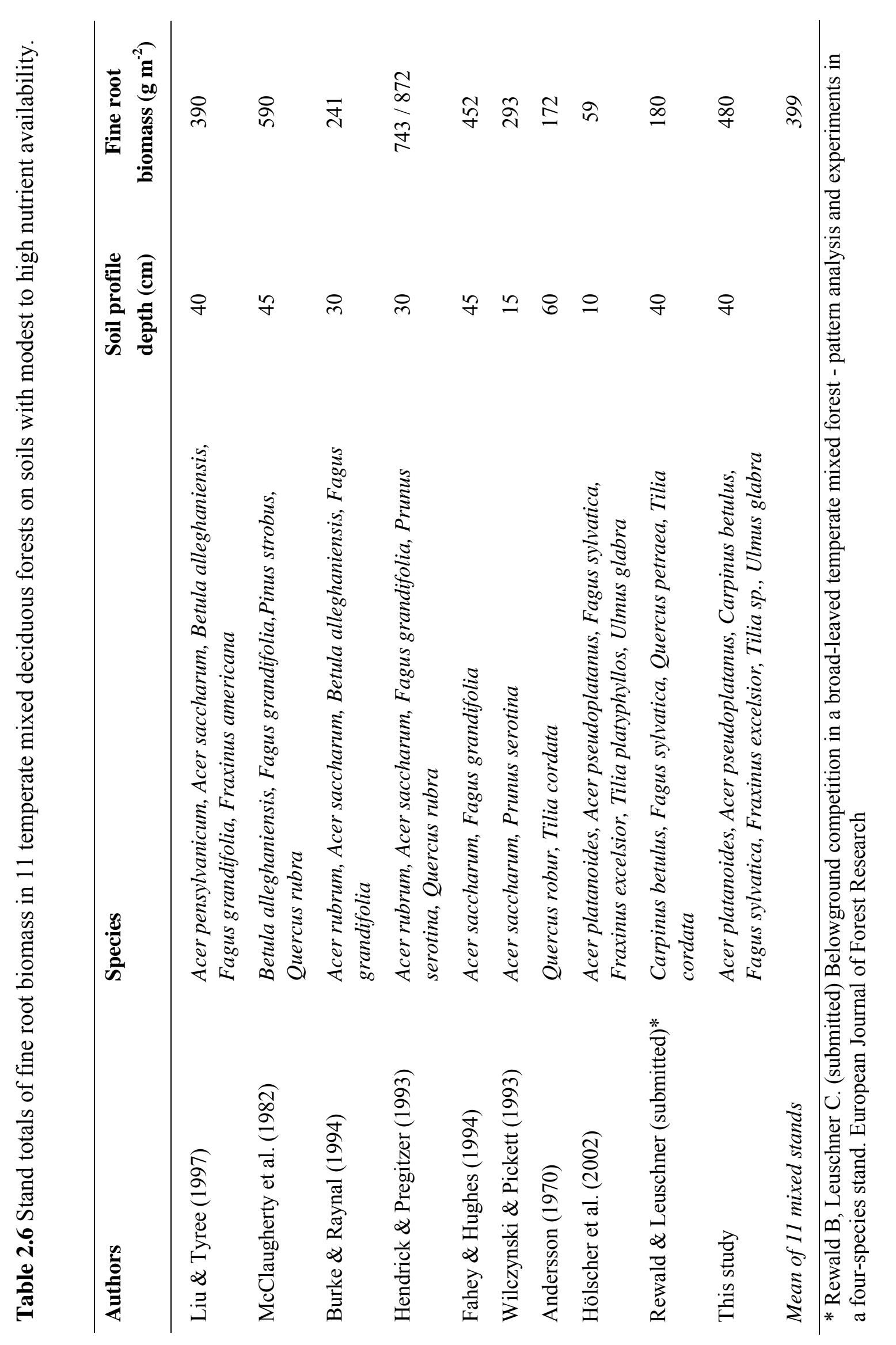




\section{Differences in fine root morphology between tree species and between pure} and mixed stands

Fine root biomass values may not accurately indicate the capacity of roots for water and nutrient uptake (e.g. Lehmann 2003). Roots in different soil depths can show different physiological activities (Fitter 1996, Pregitzer et al. 1998), and root morphology and age can also cause functional differences between fine root populations within a fine root system (Olsthoorn 1991, Finer et al. 1997, Leuschner et al. 2004). Root diameter distribution, specific root area (SRA), and specific root tip abundance are important morphological parameters (Reich et al. 1998, Bauhus \& Messier 1999, Majdi et al. 2001, Pregitzer et al. 2002, Comas \& Eissenstat 2004, Withington et al. 2006, Ostonen et al. 2007). Moreover, in species-rich temperate broad-leaved forests, differences in root function associated with the type of mycorrhizal infection (ECM vs. VA) may affect root activity as well.

Our study revealed some marked differences in fine root morphological traits between the co-occurring species. Interestingly, there were no systematic differences in fine root morphology between tree species infected by ectomycorrhiza-forming fungi (Fagus, Tilia, Carpinus, Ulmus, Quercus, Prunus) and tree species with arbuscular mycorrhiza (Fraxinus and Acer). On the contrary, the VA-infected genera Fraxinus and Acer showed the two most dissimilar fine root architectures, with Acer (A. platanoides and A. pseudoplatanus) exhibiting fine roots of particular small diameter, large SRA values and high specific root tip abundance, while Fraxinus possesses fine roots with large diameters, small SRAs and low specific root tip abundance. The ECM-infected species were less variable in their fine root morphological traits, ranging with their values between the two VA-infected species. Data on fine root morphology of broad-leaved tree species from other forests in Central Europe are rare: Withington et al. (2006) found similar fine root diameter distributions for Fagus and Tilia species, but higher fine root diameters in Acer species as compared to our study. The SRA records for Tilia, Fagus, Fraxinus, Acer, and Ulmus in the study of Hölscher et al. (2002) were somewhat lower than our results, but confirmed the large difference between the two VA-infected genera Acer and Fraxinus. Data on specific root tip abundance in fine roots of different deciduous tree species in Europe are virtually missing in the literature.

Given the apparent species-specific differences in root morphology between different cooccurring tree species, effects of altered tree species diversity on fine root architecture in 
general could not be detected in our study. Exceptions were only found in Fagus fine roots that showed smaller fine root diameters and higher specific root tip abundances and SRA values in DL 2 plots than in the monospecific beech plots (DL 1); similarly, Tilia fine roots showed higher SRA values in the species-rich DL 3 plots than in DL 2 plots, while root diameter and root tip frequency remained unchanged. The overall lack of changes in fine root morphology in response to the presence of allospecific competitors is surprising, since several authors have emphasized the meaning of architectural plasticity versus allocational plasticity as an important adaptation mode to variable growth conditions (e.g. Bauhus \& Messier 1999, Curt \& Prévosto 2003). According to the optimality theory in plant ecology (Bloom et al. 1985, Eissenstat 1992), Ostonen et al. (2007) described two main strategies of tree fine roots to adapt to different regimes of soil nutrient supply: trees could either enhance their carbon investment to increase the fine root biomass (and root length) or increase their nutrient uptake efficiency by changes in root morphology to form fine roots of higher SRA. Similar strategies have also been suggested to explain differences in root competition ability of different tree species (Bauhus \& Messier 1999, Curt \& Prévosto 2003). Hence, the apparent changes in fine root morphology of Fagus and Tilia in our study may represent responses to a higher interspecific competition intensity due to the presence of a larger number of tree species in the DL 2 and DL 3 plots, respectively. A similar result has been reported by Bolte \& Villanueva (2006) for Fagus fine roots when admixed to Picea abies. On the other hand, for pure Fagus stands at sites differing in soil fertility, Leuschner et al. (2004) reported that fine root morphology remained nearly unaffected by differences in soil acidity and nutrient concentration. Not only changes in root morphology might help trees to optimize their cost-benefit ratio of fine roots, but differences in roots may be as crucial in this context (Eissenstat \& Yanai 1997, Eissenstat et al. 2000, Withington et al. 2006). Bauhus \& Messier (1999) concluded that thicker and less ramified fine roots of conifers (which in this sense resemble the Fraxinus fine roots of our study) might live longer than fine roots of deciduous trees and, hence, may not necessarily be more cost-intensive. However, in the absence of direct observations on root dynamics, any differences in fine root longevity remain speculative.

Although fine root morphology differed among the tree species, it had no significant influence on stand totals of fine root biomass. Root tip abundance (number of root tips per $\mathrm{m}^{2}$ ground area) tended to be lower in the species-rich DL 3 plots due to the low specific root tip abundance of Fraxinus, but this finding was not statistically significant. The root surface area indices of the stands, on the other hand, were almost identical between the 
diversity levels but high in comparison to literature data (see Jackson et al. 1997 and Leuschner et al. 2004), thus confirming that the upper soil horizons in our study plots were densely exploited by fine roots independently of the composition of the tree layer.

\section{Conclusions}

Our two hypotheses were not supported by the data from the 12 deciduous forest stands: Fine root biomass of the stands was not affected by the number of tree species present, which is possibly explained by the lack of vertical niche segregation of the root systems. This does not fully exclude that 'overyielding' does occur in species-rich stands since root productivity data are not yet available. The identity of co-occurring tree species had no significant influence on the morphology of the roots; root diameter distribution, tip frequency and specific root surface area showed characteristic differences among the species, but were more or less similar in monospecific and species-rich stands. Thus, the tree species were rather conservative with regard to the morphological plasticity of their fine roots and also the vertical fine root distribution patterns. This held true although the recorded fine root biomasses as well as the total root surface areas of the stands indicate rather high fine root densities that should cause intense below-ground competition. However, it remains open whether species-specific differences in fine root lifespan affect the below-ground productivity of the studied stands.

\section{Acknowledgements}

This study was conducted in the context of Graduiertenkolleg 1086 "The role of biodiversity for biogeochemical cycles and biotic interactions in temperate deciduous forests". We are very grateful to the National Park administration for the permission to conduct the study in the Hainich National Park and for funding by the German Research Council (DFG). We thank all participants of the Graduiertenkolleg for excellent teamwork. Data of forest stand parameters were kindly provided by Mascha Brauns, Anja Guckland, Andreas Mölder and Inga Schmidt. 


\subsection{References}

Andersson F (1970) Ecological studies in a scanian woodland and meadow area, southern Sweden. 2. Plant biomass, primary production and turnover of organic matter. Botaniska Notiser 123:8-51

Bauhus J, Bartsch N (1996) Fine-root growth in beech (Fagus sylvatica) forest gaps. Canadian Journal of Forest Research 26:2153-2159

Bauhus J, Khanna PK, Menden N (2000) Aboveground and belowground interactions in mixed plantations of Eucalyptus globulus and Acacia mearnsii. Canadian Journal of Forest Research 30:1886-1894

Bauhus J, Messier C (1999) Soil exploitation strategies of fine roots in different tree species of the southern boreal forest of eastern Canada. Canadian Journal of Forest Research 29:260-273

Berish CW, Ewel JJ (1988) Root development in simple and complex tropical successional ecosystems. Plant and Soil 106:73-84

Blair JM, Parmelee RW, Beare MH (1990) Decay-rates, nitrogen fluxes, and decomposer communities of single-species and mixed-species foliar litter. Ecology 71:19761985

Bloom AJ, Chapin FS, Mooney HA (1985) Resource limitations in plants - an economic analogy. Annual Review of Ecology and Systematics 16:363-392

Bolte A, Villanueva I (2006) Interspecific competition impacts on the morphology and distribution of fine roots in European beech (Fagus sylvatica L.) and Norway spruce (Picea abies (L.) Karst.). European Journal of Forest Research 125:15-26

Brown AFH (1992) Functioning of mixed-species stands at Gisburn, N.W. England. In: Cannell MGR, Malcolm DC, Robertson PA (eds) The Ecology of Mixed-Species Stands of Trees. Blackwell, Oxford, pp 125-150

Burke MK, Raynal DJ (1994) Fine root growth, phenology, production, and turnover in a northern hardwood forest ecosystem. Plant and Soil 162:135-146

Büttner V, Leuschner C (1994) Spatial and temporal patterns of fine-root abundance in a mixed Oak-Beech forest. Forest Ecology and Management 70:11-21

Comas LH, Eissenstat DM (2004) Linking fine root traits to maximum potential growth rate among 11 mature temperate tree species. Functional Ecology 18:388-397

Cuevas E, Brown S, Lugo AE (1991) Aboveground and belowground organic-matter storage and production in a tropical pine plantation and a paired broadleaf secondary forest. Plant and Soil 135:257-268

Curt T, Prévosto B (2003) Rooting strategy of naturally regenerated beech in Silver birch and Scots pine woodlands. Plant and Soil 255:265-279 
DeAngelis DL, Gardner RH, Shugart HH (1981) Productivity of forest ecosystems studies during IBP: the woodland data set. In: Reichle DE (ed) Dynamic properties of forest ecosystems. Cambridge University Press, Cambridge, pp 567-659

Eissenstat DM (1992) Costs and benefits of constructing roots of small diameter. Journal of Plant Nutrition 15:763-782

Eissenstat DM, Yanai RD (1997) The ecology of root lifespan. Academic Press, London

Eissenstat DM, Wells CE, Yanai RD, Whitbeck JL (2000) Building roots in a changing environment: implications for root longevity. New Phytologist 147:33-42

Enquist BJ, Niklas KJ (2001) Invariant scaling relations across tree-dominated communities. Nature 410:655-660

Erskine PD, Lamb D, Bristow M (2006) Tree species diversity and ecosystem function: Can tropical multi-species plantations generate greater productivity? Forest Ecology and Management 233:205-210

Fahey TJ, Hughes JW (1994) Fine root dynamics in a northern hardwood forest ecosystem, Hubbard Brook Experimental Forest, NH. Journal of Ecology 82:533-548

FAO (2006) World reference base for soil resources 2006. World soil resources reports 103. FAO, Rome

Finer L, Messier C, DeGrandpre L (1997) Fine-root dynamics in mixed boreal coniferbroad-leafed forest stands at different successional stages after fire. Canadian Journal of Forest Research 27:304-314

Fitter A (1996) Characteristics and functions of root systems. In: Weisel Y, Eshel A, Kafkafi U (eds) Plant roots: the hidden half. Dekker, New York, pp 1-20

Fogel R, Hunt G (1983) Contribution of mycorrhizae and soil fungi to nutrient cycling in a Douglas-fir ecosystem. Canadian Journal of Forest Research 13:219-232

Gale MR, Grigal DF (1987) Vertical root distributions of northern tree species in relation to successional status. Canadian Journal of Forest Research 17:829-834

Guckland A, Brauns M, Flessa H, Thomas FM, Leuschner C (2008) Acidity, nutrient stocks and organic matter content in soils of a temperate deciduous forest with different abundance of European beech (Fagus sylvatica L.). Journal of Plant Nutrition and Soil Science. in Press

Hector A, Schmid B, Beierkuhnlein C, Caldeira MC, Diemer M, Dimitrakopoulos PG, Finn JA, Freitas H, Giller PS, Good J, Harris R, Högberg P, Huss-Danell K, Joshi J, Jumpponen A, Körner C, Leadley PW, Loreau M, Minns A, Mulder CPH, O'Donovan G, Otway SJ, Pereira JS, Prinz A, Read DJ, Scherer-Lorenzen M, Schulze ED, Siamantziouras ASD, Spehn EM, Terry AC, Troumbis AY, Woodward FI, Yachi S, Lawton JH (1999) Plant diversity and productivity experiments in European grasslands. Science 286:1123-1127 
Hector A (2001) Biodiversity and functioning of grassland ecosystems: Multi-site comparison. In: Kinzig AP, Tilman D, Pacala SW (eds) The Functional Consequences of Biodiversity: Empirical Progress and Theoretical Extensions. vol 33. Princton University Press, Princeton, pp 71-95

Hendrick RL, Pregitzer KS (1993) The dynamics of fine root length, biomass, and nitrogen content in two northern hardwood ecosystems. Canadian Journal of Forest Research 23:2507-2520

Hendriks CMA, Bianchi FJJA (1995) Root density and root biomass in pure and mixed forest stands of Donglas-fir and Beech. Netherlands Journal of Agricultural Science 43:321-331

Hertel D (1999) Das Feinwurzelsystem von Rein- und Mischbeständen der Rotbuche: Struktur, Dynamik und interspezifische Konkurrenz. Dissertationes Botanicae 317. Gebrüder Borntraeger, Berlin, Stuttgart

Hölscher D, Hertel D, Leuschner C, Hottkowitz M (2002) Tree species diversity and soil patchiness in a temperate broad-leaved forest with limited rooting space. Flora 197:118-125

Hooper DU, Vitousek PM (1997) The effects of plant composition and diversity on ecosystem processes. Science 277:1302-1305

Jackson RB, Canadell J, Ehleringer JR, Mooney HA, Sala OE, Schulze ED (1996) A global analysis of root distributions for terrestrial biomes. Oecologia 108:389-411

Jackson RB, Mooney HA, Schulze ED (1997) A global budget for fine root biomass, surface area, and nutrient contents. Proceedings of the National Academy of Sciences of the United States of America 94:7362-7366

Jolliffe PA (1997) Are mixed populations of plant species more productive than pure stands? Oikos 80:595-602

Jose S, Williams R, Zamora D (2006) Belowground ecological interactions in mixedspecies forest plantations. Forest Ecology and Management 233:231-239

Joshi J, Matthies D, Schmid B (2000) Root hemiparasites and plant diversity in experimental grassland communities. Journal of Ecology 88:634-644

Keyes MR, Grier CC (1981) Above- and below-ground net production in 40-year old Douglas-fir stands on low and high productivity sites. Canadian Journal of Forest Research 11:599-605

Légaré S, Bergeron Y, Pare D (2005) Effect of aspen (Populus tremuloides) as a companion species on the growth of black spruce (Picea mariana) in the southwestern boreal forest of Quebec. Forest Ecology and Management 208:211222

Lehmann J (2003) Subsoil root activity in tree-based cropping systems. Plant and Soil 255:319-331 
Leuschner C, Hertel D, Coners H, Büttner V (2001) Root competition between beech and oak: a hypothesis. Oecologia 126:276-284

Leuschner C, Hertel D (2003) Fine root biomass of temperate forests in relation to soil acidity and fertility, climate, age and species. Progress in Botany 64:405-438

Leuschner C, Hertel D, Schmid I, Koch O, Muhs A, Hölscher D (2004) Stand fine root biomass and fine root morphology in old-growth beech forests as a function of precipitation and soil fertility. Plant and Soil 258:43-56

Leuschner C, Jungkunst HF, Fleck S (2008) Functional role of forest diversity: Pros and cons of synthetic stands and across-site comparisons in established forests. Basic and Applied Ecology. In press

Lohmus K, Oja T, Lasn R (1989) Specific root area - a soil characteristic. Plant and Soil 119:245-249

Loreau M, Hector A (2001) Partitioning selection and complementarity in biodiversity experiments. Nature 412:72-76

Lui X, Tyree MT (1997) Root carbohydrate reserves, mineral nutrient concentrations and biomass in a healthy and a declining sugar maple (Acer saccharum) stand. Tree Physiology 17:179-185

Majdi H, Damm E, Nylund JE (2001) Longevity of mycorrhizal roots depends on branching order and nutrient availability. New Phytologist 150:195-202

McClaugherty CA, Aber JD, Melillo JM (1982) The role of fine roots in the organic matter and nitrogen budgets of two forested ecosystems. Ecology 63:1481-1490

Mölder A, Bernhardt-Römermann M, Schmidt W (2006) Forest ecosystem research in Hainich National Park (Thuringia): First results on flora and vegetation in stands with contrasting tree species diversity. Waldoekologie online 3:83-99

Mölder A, Bernhardt-Römermann M, Schmidt W (2008) Herb-layer diversity in deciduous forests: Raised by tree richness or beaten by beech? Forest Ecology and Management 256: 272-281

Morgan JL, Campbell JM, Malcolm DC (1992) Nitrogen relations of mixed-species stands on oligotrophic soils. In: Cannell MGR, Malcolm DC, Robertson PA (eds) The ecology of mixed-species stands of trees. Blackwell, London, pp 65-85

Olsthoorn AFM (1991) Fine root density and root biomass of 2 Douglas-fir stands on sandy soils in the Netherlands. 1.Root biomass in early summer. Netherlands Journal of Agricultural Science 39:49-60

Ostonen I, Lohmus K, Helmisaari HS, Truu J, Meel S (2007) Fine root morphological adaptations in Scots pine, Norway spruce and Silver birch along a latitudinal gradient in boreal forests. Tree Physiology 27:1627-1634

Parrish JAD, Bazzaz FA (1976) Underground niche separation in successional plants. Ecology 57:1281-1288 
Persson H (1978) Root dynamics in a young Scots pine stand in Central Sweden. Oikos 30:508-519

Pregitzer KS, Laskowski MJ, Burton AJ, Lessard VC, Zak DR (1998) Variation in sugar maple root respiration with root diameter and soil depth. Tree Physiology 18:665670

Pregitzer KS, DeForest JL, Burton AJ, Allen MF, Ruess RW, Hendrick RL (2002) Fine root architecture of nine North American trees. Ecological Monographs 72:293-309

Pretzsch H (2005) Diversity and productivity in forests: evidence from long-term experimental plots. In: Scherer-Lorenzen M, Körner Ch, Schulze ED (eds) Forest Diversity and function: temperate and boreal systems. Ecological Studies 176. Springer, Berlin, Heidelberg, New York, pp 41-64

Quested HM, Callaghan TV, Cornelissen JHC, Press MC (2005) The impact of hemiparasitic plant litter on decomposition: direct, seasonal and litter mixing effects. Journal of Ecology 93:87-98

Reich PB, Walters MB, Tjoelker MG, Vanderklein D, Buschena C (1998) Photosynthesis and respiration rates depend on leaf and root morphology and nitrogen concentration in nine boreal tree species differing in relative growth rate. Functional Ecology 12:395-405

Rust S, Savill PS (2000) The root systems of Fraxinus excelsior and Fagus sylvatica and their competitive relationships. Forestry 73:499-508

Scherer-Lorenzen M, Körner Ch, Schulze ED (2005) The functional significance of forestdiversity: a synthesis. In: Scherer-Lorenzen M, Körner Ch, Schulze ED (eds) Forest Diversity and function: temperate and boreal systems. Ecological Studies 176. Springer, Berlin, Heidelberg, New York, pp 377-390

Schlesinger WH (1997) Biogeochemistry. An analysis of global change. Academic Press, San Diego

Schmid B, Joshi J, Schläpfer F (2001) Empirical evidence for biodiversity-ecosystem functioning relationships. In: Kinzig AP, Pacala SW, Tilman D (eds) The Functional Consequences of Biodiversity: Empirical Progress and Theoretical Extensions. vol 33. Princton University Press, Princton, pp 120-150

Schmid I (2002) The influence of soil type and interspecific competition on the fine root system of Norway spruce and European beech. Basic and Applied Ecology 3:339346

Schmid I, Kazda M (2002) Root distribution of Norway spruce in monospecific and mixed stands on different soils. Forest Ecology and Management 159:37-47

Smith FW, Long JN (1992) A comparison of stemwood production in monocultures and mixtures of Pinus contorta var. latifolia and Abies lasiocarpa. In: Cannell MGR, Malcolm DC, Robertson PA (eds) The ecology of mixed-species stands of trees. Blackwell, London, pp 87-98 
Spehn EM, Joshi J, Schmid B, Diemer M, Körner C (2000) Above-ground resource use increases with plant species richness in experimental grassland ecosystems. Functional Ecology 14:326-337

Szwagrzyk J, Gazda A (2007) Above-ground standing biomass and tree species diversity in natural stands of Central Europe. Journal of Vegetation Science 18:555-562

Tilman D, Wedin D, Knops J (1996) Productivity and sustainability influenced by biodiversity in grassland ecosystems. Nature 379:718-720

van Praag HJ, Sougnezremy S, Weissen F, Carletti G (1988) Root turnover in a beech and a spruce stand of the Belgian Ardennes. Plant and Soil 105:87-103

Vilà M, Vayreda J, Gracia C, Ibanez JJ (2003) Does tree diversity increase wood production in pine forests? Oecologia 135:299-303

Vitousek PM, Hooper DU (1993) Biological diversity and terrestrial ecosystem biogeochemistry. In: Schulze ED, Mooney HA (eds) Biodiversity and ecosystem function. Springer, Berlin, pp 3-14

Wilczynski CJ, Pickett STA (1993) Fine root biomass within experimental canopy gaps:evidence for a below-ground gap. Journal of Vegetation Science 4:571-574

Withington JM, Reich PB, Oleksyn J, Eissenstat DM (2006) Comparisons of structure and life span in roots and leaves among temperate trees. Ecological Monographs 76:381-397

Yanai RD (1992) Competitive interactions between Norway spruce and Scots pine at Gisburn Forest, Nw England. Forestry 65:435-451 
CHAPTER

No evidence of spatial root system segregation and elevated root biomass in species-rich temperate broad-leaved forests 


\subsection{Abstract}

Whether stand fine root biomass increases, and root system segregation in different soil layers is more distinct in species-rich than in species-poor forests, indicating the complementary use of below-ground resources, cannot be answered unambiguously. In a temperate broad-leaved forest with a mosaic of species-poor and species-rich stands, we tested two hypotheses related to putative below-ground 'overyielding' in species-rich forests, (i) that species mixtures result in a partial spatial segregation of the fine root systems of different species, and (ii) that stand fine root biomass increases with increasing tree species diversity. We developed a morphological key to identify the fine roots of different tree species by colour, periderm surface structure and branching patterns. We investigated 12 stands with either one, three or five dominant tree species (4 replicate stands each) under similar soil and climate conditions for stand fine root biomass (diameter $<2 \mathrm{~mm}$ ) and spatial root segregation in vertical and horizontal direction in the soil. In species-poor and species-rich stands, and in all tree species present, fine root density (biomass per soil volume) decreased exponentially with soil depth at very similar rates. Stand fine root biomass in the densely rooted upper soil $(0-40 \mathrm{~cm}$ depth) was not significantly different between stands with 1,3 or 5 dominant tree species. Moreover, indications of a spatial segregation of the root systems of different species in the speciesrich stands were not found. We conclude that the absence of 'below-ground overyielding' i.e. a higher fine root biomass in the species-rich stands as compared to the monospecific ones results from the similar vertical root distribution patterns of the tree species with no additional soil volume being explored in the more diverse stands. 


\subsection{Introduction}

Evidence from experiments with synthetic grasslands suggests that above-ground plant biomass and productivity may increase with increasing numbers of plant species and/or plant functional types present (Tilman et al. 1996; Hooper \& Vitousek 1997; Tilman et al. 1997; Hector et al. 1999; Spehn et al. 2000; Loreau \& Hector 2001). One explanation of overyielding, i.e. higher productivity of mixtures than of the respective monocultures, is complementary use of light, water or nutrients by the component species. While complementarity in light capture and above-ground productivity has attracted much attention, the spatial arrangement of plant root systems and their water and nutrient uptake activity in monospecific and mixed forests have only rarely been studied.

Thus, the physiological basis for possible overyielding in species-rich plant communities is not well understood for the below-ground compartment. This is especially true for forests which only recently have been included in the search for the ecological functions of biodiversity (Scherer-Lorenzen et al. 2007).

While we are aware of no study that has compared fine root production in mixed and monospecific forest stands, a number of investigations found a higher fine root biomass in mixed stands (Hendriks \& Bianchi 1995; Schmid 2002; Schmid \& Kazda 2002); others, however, reported no differences or the opposite (Morgan et al. 1992; Hertel 1999; Bauhus et al. 2000; Leuschner et al. 2001). Most of these studies referred to two-species stands, while species-rich forests have only rarely been investigated for their root systems. One reason is the difficult identification of tree species by their fine roots, which hinders the analysis of species-specific root distribution patterns in mixed forests. Consequently, not much is known about space partitioning among the root systems of different coexisting tree species, neither with respect to the layering of the root systems in vertical direction, nor in terms of horizontal root extension and the degree of overlap between neighbouring trees (Stone \& Kalisz 1991; Casper \& Jackson 1997).

In this study in a species-rich broad-leaved forest with more than 5 tree species, we developed a morphological key to identify the species by colour, periderm surface structure and branching patterns, which enabled us to analyse the vertical layering and horizontal extension of the fine root systems of different species separately. Due to a finescale mosaic of different land use histories in the forest, species-poor and species-rich forest stands existed in close proximity to one another under similar soil and climate 
conditions allowing us to investigate the effect of tree species diversity and/or species identity on stand fine root biomass and spatial root distribution patterns.

We tested the hypotheses that (i) tree species mixture results in a spatial segregation of the fine root systems with preference of different soil layers by the species, (ii) the root systems of different tree species overlap largely in horizontal direction, i.e. are not 'territorial' in the sense of Schenk et al. (1999), (iii) stand fine root biomass increases with increasing tree species diversity, and (iv) fine roots of tree saplings contribute significantly to total fine root biomass in stands with abundant offspring.

\subsection{Materials and methods}

\section{Study site}

The study was conducted in a mature broad-leaved deciduous forest in the Hainich National Park in Thuringia (Germany). The most abundant tree species in this area is European beech (Fagus sylvatica L.), but due to former forest practice, some stands consist of up to 14 tree species. In the north-eastern part of the National Park, 12 study plots $(50 \mathrm{~m}$ x $50 \mathrm{~m}$ ) were selected spanning a gradient from low to high tree species diversity. Diversity level 1 (DL 1) plots were dominated by Fagus sylvatica (proportion of basal area $>95 \%$ ). Plots of diversity level 2 (DL 2) were formed by Fagus s., Tilia species (Tilia cordata Mill. and T. platyphyllos Scop.) and Fraxinus excelsior L. Diversity level 3 (DL 3) plots were built mainly by five tree species: Fagus, Tilia (both species), Fraxinus, Carpinus betulus L. and Acer species (Acer pseudoplatanus L. and A. platanoides L.). In some DL 3 plots, Quercus robur L., Q. petraea Liebl., Prunus avium L. and Ulmus glabra L. occurred with few individuals. Four study plots per diversity level were selected as replicates.

All plots represented mature forest stands with a closed canopy and a mean tree age of about 100 years. The Fagus trees on the DL 1 plots were somewhat older (mean: 146 years), however, tree height of the canopy trees ranged between 26 and $38 \mathrm{~m}$ (Table 3.1). The studied stands had similar basal areas (32 to $46 \mathrm{~m}^{2} \mathrm{ha}^{-1}$ ). Mean tree sapling density was 31,600 individuals per hectare in the DL 1 plots, while the density in the DL 3 plots was almost fourfold higher (Mölder et al. 2008). 


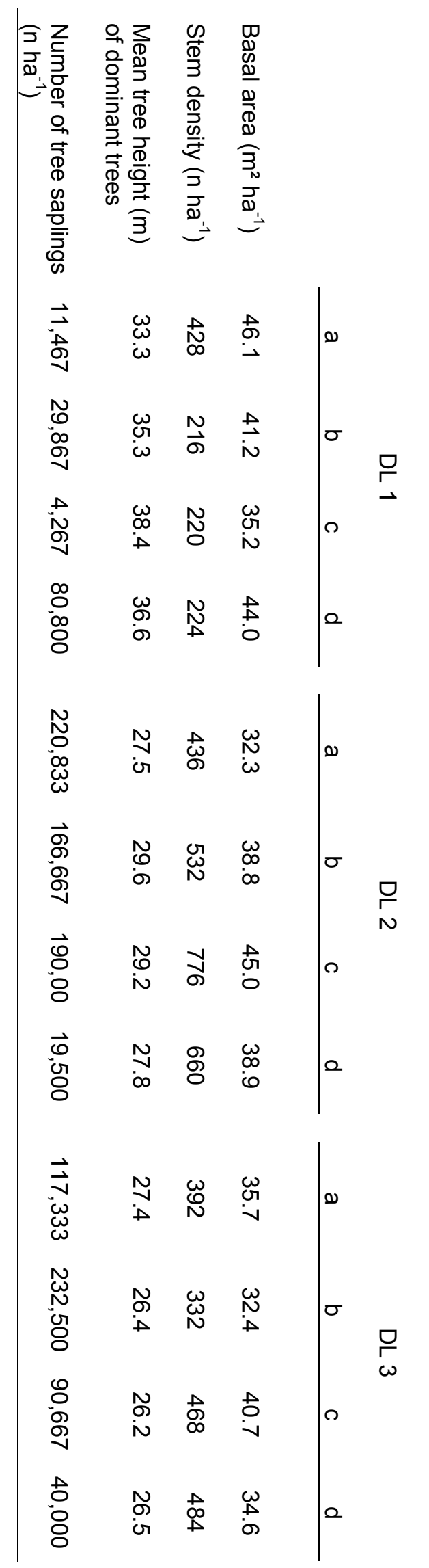

营 븡

훈

है

$\exists \underset{0}{0}$

$-0$

ㄴ.

的

ज.

$\leq$

实

苘

$\because \overline{0}$

NI

ㄹ.

용요

$\ddot{\vec{\nabla}}$

造

을

$\forall$ ह

w $\frac{0}{0}$

륭

S.

$\stackrel{2}{2}$

Q

D

w

ڤ

超

용

$\stackrel{9}{\circ} \stackrel{0}{\circ}$

串 है

范

䒿.

वृ

$\rightarrow$

응

उ家

융

Q

$\cong$

กิ

હ্ঠ 
Mean annual precipitation in the study region was $670 \mathrm{~mm}$ and annual temperature averaged at $7.5{ }^{\circ} \mathrm{C}$ (data from the nearby weather station Weberstedt/Hainich). The elevation of the plots was about $350 \mathrm{~m}$ a.s.1. The soils developed from Triassic limestone covered by loess (minimum depth: $60 \mathrm{~cm}$ ). The $\mathrm{pH}\left(\mathrm{H}_{2} \mathrm{O}\right)$ in $0-10 \mathrm{~cm}$ soil depth ranged from 4.6 to 6.7. The soil type was a Luvisol (WRB 2006 taxonomy) with stagnic properties in spring and winter and a dry period in summer. The soil texture of the mineral soil (0-30 $\mathrm{cm}$ ) was characterised by high silt $(74 \%)$, but low sand $(<5 \%)$ content (Guckland et al. 2008). In the stands dominated by Fagus, the base saturation was lower than in the mixed stands, which is thought to be a consequence of the higher acidification potential of beech leaves. Detailed information on study plot selection and stand characteristics are given in Leuschner et al. (2008) and Mölder et al. (2006).

\section{Fine root sampling}

In order to analyse biomass and spatial distribution of the fine roots, 24 sampling locations were randomly selected in each study plot. The sampling locations had a minimum distance to each other of $1 \mathrm{~m}$. Soil samples were taken in summer of 2005 and 2006 with a sharp soil corer $(3.5 \mathrm{~cm}$ in diameter) from the organic litter layer and the upper mineral soil down to $40 \mathrm{~cm}$ soil depth. The cores were divided in the 0-10, 10-20, 20-30 and 30-40 cm soil layers. In order to extract all fine roots (diameter $<2 \mathrm{~mm}$ ) from the soil, the samples were shortly soaked in water and the roots washed out in a sieve (mesh size $0.25 \mathrm{~mm}$ ). Fine root fragments longer than $1 \mathrm{~cm}$ were collected by hand with a pair of tweezers and sorted under a stereo-microscope for live and dead fractions. Morphological parameters as the degree of cohesion of root stele and periderm, root elasticity or the total loss of the stele were used for separating live and dead roots (Persson 1978; Leuschner et al. 2001).

Based on an identification key established for the relevant tree species by Hölscher et al. (2002) and Korn (2004), we identified the roots by morphological characteristics (fine root surface structure, colour of the periderm, ramification patterns and type of mycorrhizal infection). Grass and herb roots were distinguished from tree roots by their smaller diameter, non-lignified structure and lighter colour. Fine root biomass and fine root necromass were dried at $70{ }^{\circ} \mathrm{C}$ for $48 \mathrm{~h}$ and weighed. The data was used to analyse the vertical and horizontal distribution of the fine roots by species and to calculate the stands' total fine root biomass (unit: $\mathrm{g} \mathrm{m}^{-2}$ ). 
In order to analyse the contribution of tree saplings to the stands' fine root biomass, saplings of Fagus sylvatica, Fraxinus excelsior and Acer pseudoplatanus were excavated next to the DL 3 plots (20 saplings per species). These three species accounted for $>90 \%$ of the total number of saplings present in the stands. For Fraxinus and Acer, saplings of three different height classes (5-20, 20-40 and 40-60 cm) were sampled; for Fagus, an additional height class $(60-80 \mathrm{~cm})$ was investigated to cover the size spectrum of saplings present.

The root mass (fine roots $<2 \mathrm{~mm}$ and coarse roots $>2 \mathrm{~mm}$ in diameter) of the saplings was extracted from the excavated soil and dried $\left(70{ }^{\circ} \mathrm{C}\right.$ for $\left.48 \mathrm{~h}\right)$. The proportion of sapling root mass in the stand total of fine root biomass was estimated from the fine root biomass data obtained by sapling excavation and the abundance of tree saplings in the respective stand (Mölder et al. 2008).

\section{Statistical analyses}

We used the asymptotic model with the equitation $y=1-\beta^{d}$ (Gale and Grigal 1987) to describe the vertical decrease in fine root density with increasing soil depth, where y expresses the cumulative fine root fraction contained in the soil from the surface the soil depth $\mathrm{d}$ (in cm). High $\beta$ values (ca. 0.98) indicate a large proportion of fine root biomass in a deeper soil depth, low $\beta$ values (ca. 0.90) stand for a large proportion of fine roots near the soil surface. The $\beta$ values were calculated individually for each tree species being present in the 12 plots. The regression fits were calculated with the software package Xact (version 8.03, SciLab, Hamburg, Germany).

For each sampling location, the distance to the surrounding trees was measured. In order to analyse the horizontal distribution of fine root biomass by species, linear or simple logistic regression models were used to fit root biomass data to the distance of the nearest stem of the respective species. For the calculations, only the maximum root biomass values per distance class were used (software package Xact version 8.03, SciLab, Hamburg, Germany).

All data sets on fine root mass were tested for normal distribution using a Shapiro-Wilk test. The $\beta$ values showed normal distribution and were compared between the diversity levels for each species, between the species for each diversity level, and between the stand totals by ANOVA followed by Scheffé f-test. The root biomass data were non-normally distributed and remained skewed after log or root transformation. Therefore, a Kruskal- 
Wallis single factor analysis of variance followed by non-parametric Mann-Whitney two sample U-tests was applied to detect significant differences in root biomass between the diversity levels for each species, between the species for each diversity level, and between the stand totals ( $\mathrm{p}<0.05$ in all analyses). These calculations were conducted with the software package SAS, version 8.2 (SAS Institute Inc., Cary, NC, USA).

\subsection{Results}

\section{Species composition of fine root biomass}

Stand fine root biomass $(0-40 \mathrm{~cm}$ depth) did not differ significantly between the three diversity levels (Figure 3.1). Fine root biomass ranged between $408 \mathrm{~g} \mathrm{~m}^{-2}$ in the plots of DL 1 and $466 \mathrm{~g} \mathrm{~m}^{-2}$ in the plots of DL 2. The contribution of the tree species to the stand totals of root biomass mirrored the tree species composition of the stands. The fine root biomass of the quasi monospecific DL 1 plots consisted by $96 \%$ of Fagus roots. The root biomass in the plots of DL 2 was mainly composed of Fagus (47 \%) and Fraxinus (35\%) roots, followed by roots of Tilia sp. (11\%). In contrast, fine roots of up to six species were found in the DL 3 plots. Tilia sp. and Fraxinus accounted for the majority of the fine root biomass in these stands (together $61 \%$ ), while Fagus, Acer sp. and Carpinus showed only minor contributions (11-13\%).

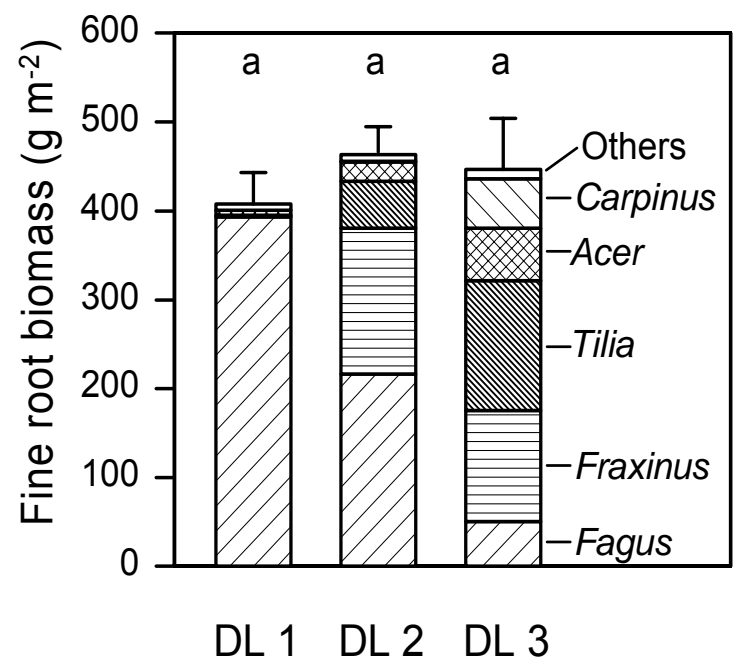

Figure 3.1 Species composition of fine root biomass in the plots of the three diversity levels. Given are means $+1 \mathrm{SE}$ of the profile totals $(0-40 \mathrm{~cm}$ soil depth) of four plot replicates per diversity level and 24 sampling locations per plot. Different letters indicate significant differences $(\mathrm{p}<0.05)$ between diversity levels. 
We found a remarkably large overlap of the fine root systems of different species not only in the mixed DL 2 and DL 3 stands, but also in the DL 1 stands, where beech contributed at least $95 \%$ to the stand's basal area. The roots of the rare admixed tree species were found in $23 \%$ of the soil samples investigated in the quasi monospecific DL 1 stands, while roots of beech occurred only in $74 \%$ of the samples (Figure 3.5). The samples of the DL 2 plots contained roots of up to five tree species with the majority ( $>93 \%$ ) being colonised by two or three species. In the most species-rich DL 3 plots, $45 \%$ of the samples contained three root species, another $49 \%$ either two or four species.

Table 3.2 Total fine root biomass of tree saplings in plots of the three diversity levels estimated from allometric fine root biomass data of the saplings $(n=20$ tree saplings per species) and sapling abundance in the plots. Given are means \pm 1 SE from four plot replicates per diversity level. Different letters indicate significant differences $(p<0.05)$ between the diversity levels for each species (Greek letters), between species for each diversity level (lower case Latin letters) or between stand totals for each diversity level (Capital letters).

\begin{tabular}{lccc}
\hline & \multicolumn{3}{c}{ Fine root biomass $\left(\mathrm{g} \mathrm{m}^{-2}\right)$} \\
Species & $\mathrm{DL} \mathrm{1}$ & $\mathrm{DL} 2$ & $\mathrm{DL} 3$ \\
\cline { 2 - 4 } Fagus sylvatica & $0.2 \pm 0.1 \mathrm{a} \alpha$ & $0.4 \pm 0.2 \mathrm{a} \alpha$ & $0.1 \pm 0.03 \mathrm{a} \alpha$ \\
Fraxinus excelsior & $0.3 \pm 0.2 \mathrm{a} \alpha$ & $0.6 \pm 0.2 \mathrm{a} \alpha$ & $0.7 \pm 0.4 \mathrm{ab} \alpha$ \\
Acer sp. & $0.5 \pm 0.1 \mathrm{a} \alpha$ & $1.2 \pm 0.7 \mathrm{a} \alpha$ & $1.1 \pm 0.4 \mathrm{~b} \alpha$ \\
& & & \\
Stand total & $1.0 \pm 0.5 \mathrm{~A}$ & $2.2 \pm 1.1 \mathrm{~A}$ & $1.9 \pm 0.4 \mathrm{~A}$ \\
\end{tabular}

\section{Fine root biomass of tree saplings}

The fine root biomass of the tree saplings ranged from $1.0 \mathrm{~g} \mathrm{~m}^{-2}$ (in the DL 1 plots) to $2.2 \mathrm{~g}$ $\mathrm{m}^{-2}$ in the plots of DL 2 (Table 3.2). In contrast to the tree species composition of the DL 1 stands, the contribution of fine root biomass from Fagus saplings was remarkably low in these monospecific stands, while Acer saplings contributed half of the fine root biomass in the sapling fraction. In fact, offspring of Acer dominated sapling fine root biomass in all plots of the diversity gradient. Nevertheless, the contribution of sapling roots to the total fine root biomass of the stands was only $0.2 \%$ in the DL 1 plots, $0.5 \%$ in the DL 2 plots and $0.4 \%$ in the DL 3 plots. 


\section{Vertical fine root distribution}

The abundance of tree fine roots decreased exponentially with increasing soil depth in the species-poor and also in the species-rich stands (Figure 3.2). In all plots, about half of the stand total of fine root biomass was found in the upper $15 \mathrm{~cm}$ of the profile. The vertical decrease of root mass was very similar in all stands as indicated by $\beta$ values between 0.93 and 0.94 (Table 3.3). When the species were analysed separately, maximum $\beta$ values reached 0.95 as in the case of Carpinus in the DL 3 plots. Lowest $\beta$ values were found for Acer sp. in the DL 2 plots and for the rare species Acer campestre, Prunus avium, Ulmus glabra, Quercus petraea and Q. robur in the DL 3 plots (0.91 and 0.90, respectively).

\section{Cumulative fine root biomass (\%)}

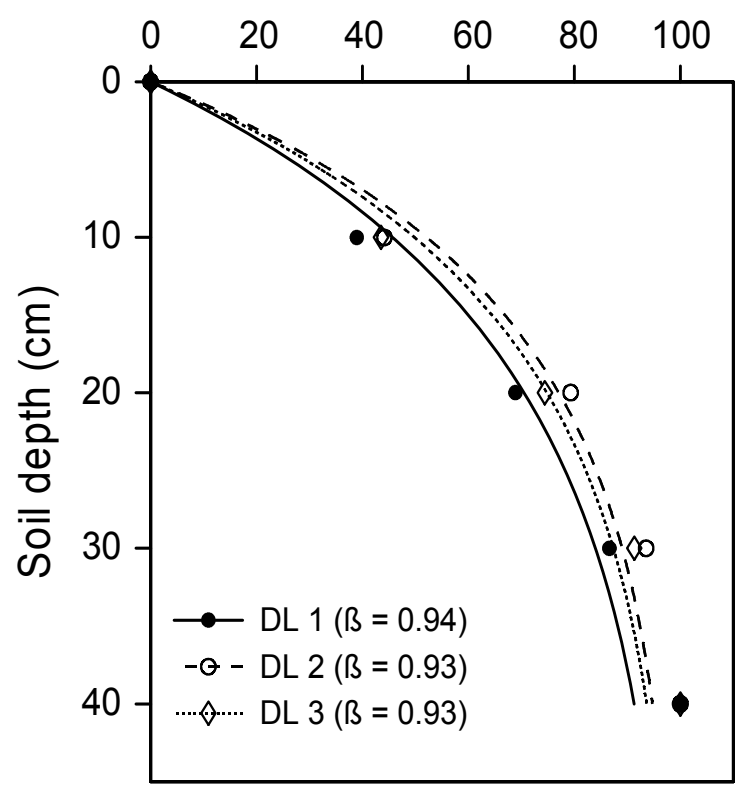

Figure 3.2 Change of cumulative fine root biomass with increasing soil depth in plots of the three diversity levels (DL). Given are means of four plot replicates per diversity level and 24 sampling locations per plot. The regression equation $y=1-\beta^{\mathrm{d}}$ (Gale and Grigal 1987) describes the change in cumulative fine root biomass fraction (y) with soil depth (d). The $\beta$ value indicates the degree of fine root biomass decrease with soil depth.

In general, the species differences and the plot differences in the $\beta$ values were very small (Figure 3.3). An exception was found in the vertical fine root distribution of Fagus in the DL 2 plots, where this species had the highest fine root density in 10-20 cm soil depth and not at the soil surface. 


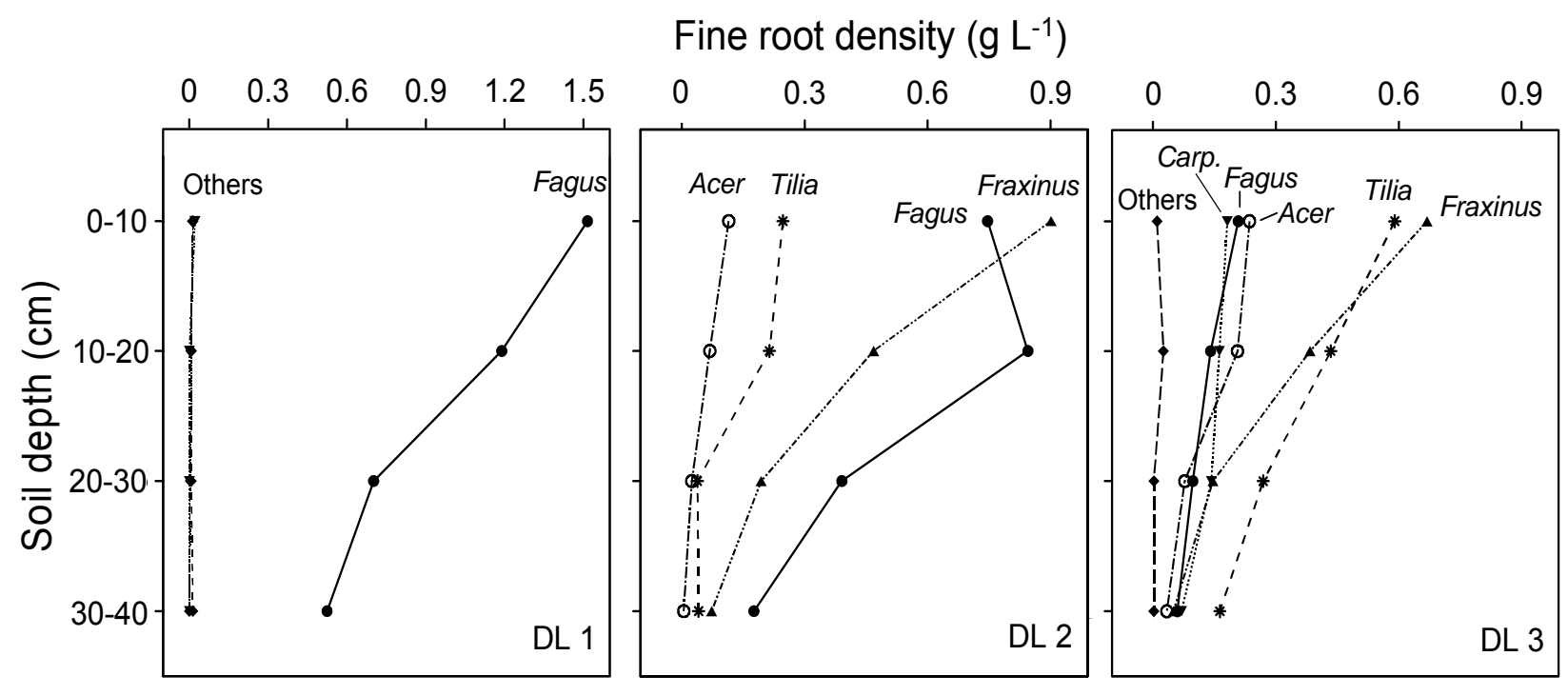

Figure 3.3 Change of fine root density with soil depth for the different tree species present in the plots of the three diversity levels (DL). Given are means of four plot replicates per diversity level and 24 sampling locations per plot. "Others" refers to fine root biomass of the rare species Acer campestre, Prunus avium, Ulmus glabra, Quercus petraea and Q. robur. Note different scales for fine root density.

Table 3.3 Vertical decrease of fine root density with soil depth as expressed by the $\beta$ value of the equation $y=1-\beta^{d}$ (with $y=$ root biomass and $d=$ soil depth, Gale and Grigal 1987) for tree species in plots of the three diversity levels. Given are means of four plot replicates per diversity level and 24 sampling locations per plot. "Other species" refers to fine root biomass of the rare species Acer campestre, Prunus avium, Ulmus glabra, Quercus petraea and Q. robur. Different letters indicate significant differences $(\mathrm{p}<0.05)$ between diversity levels for each species (Greek letters), between species for each diversity level (lower case Latin letters) or between stand totals for each diversity level (Capital letters).

\section{$B$ values}

Species

DL 1

DL 2

DL 3

Fagus sylvatica

Fraxinus excelsior

Tilia $s p$.

Acer $s p$.

Carpinus betulus

Other species
$0.94 \pm 0.007 \alpha$

$$
\begin{aligned}
& 0.94 \pm 0.002 \mathrm{a} \alpha \\
& 0.92 \pm 0.005 \mathrm{ab} \alpha \\
& 0.92 \pm 0.002 \mathrm{ab} \alpha \\
& 0.91 \pm 0.008 \mathrm{~b} \alpha
\end{aligned}
$$

Stand total
$0.94 \pm 0.007 \mathrm{~A}$

$0.93 \pm 0.005 \mathrm{~A}$
$0.93 \pm 0.02$ a $\alpha$

$0.92 \pm 0.004$ a $\alpha$

$0.93 \pm 0.006$ a $\alpha$

$0.92 \pm 0.008$ a $\alpha$

$0.95 \pm 0.008 a$

$0.90 \pm 0.02 a$ 


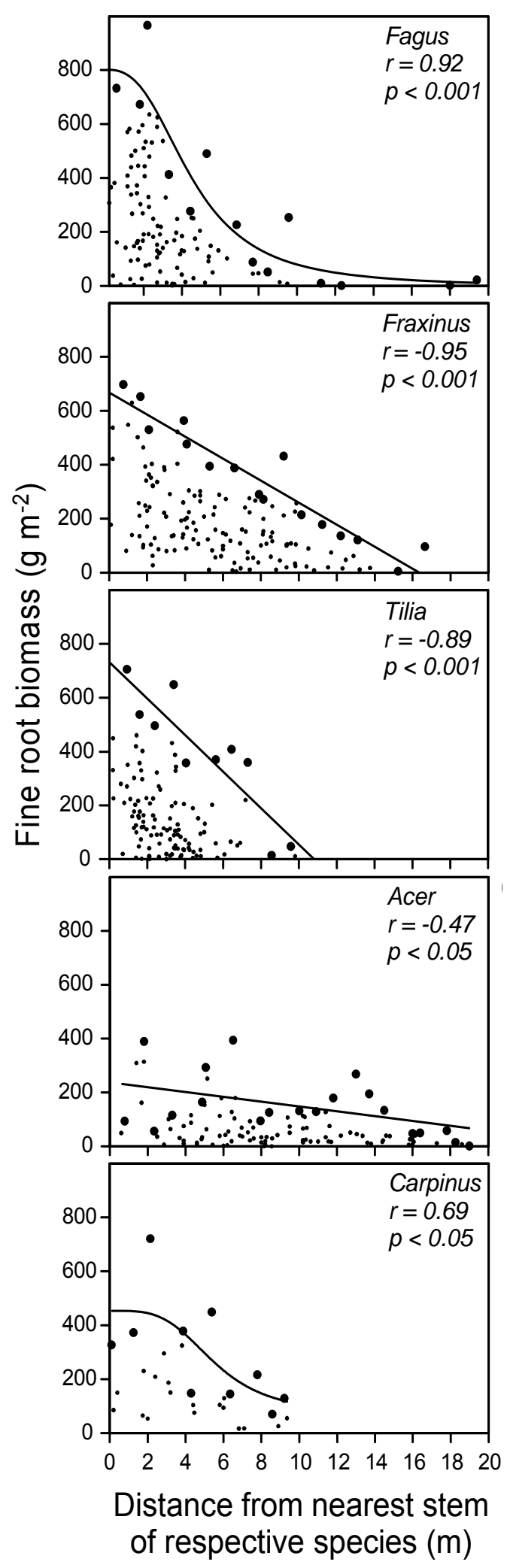

Figure 3.4 Change of fine root biomass $(0-40 \mathrm{~cm}$ profile $)$ with increasing stem distance of the most abundant tree species in the DL 2 and DL 3 plots. Maximum fine root biomass values are indicated with large dots. Given are fits of the non-linear logistic function $y=a$ $+(\mathrm{b}-\mathrm{a}) /\left(1+(\mathrm{x} / \mathrm{c})^{\mathrm{d}}\right)$ or a linear regression model of maximum fine root biomass on distance from the nearest stem of the respective species. 


\section{Horizontal fine root distribution}

The tree species differed in their patterns of horizontal fine root distribution in the mixed DL 2 and DL 3 stands (Figure 3.4). The fine roots of Fagus, Fraxinus, and Acer sp. showed relatively large horizontal extensions (up to 16-19 m from their stems), while no fine roots of Tilia sp. and Carpinus were found beyond $10 \mathrm{~m}$ distance from the stems. The decrease in fine root biomass was more or less abrupt for Fagus, Tilia sp. and Carpinus. In contrast, the fine root system of Fraxinus showed a continuous and modest decrease in biomass with distance from the nearest stem. The fine root biomass of Acer sp. displayed an only weak dependence on distance.

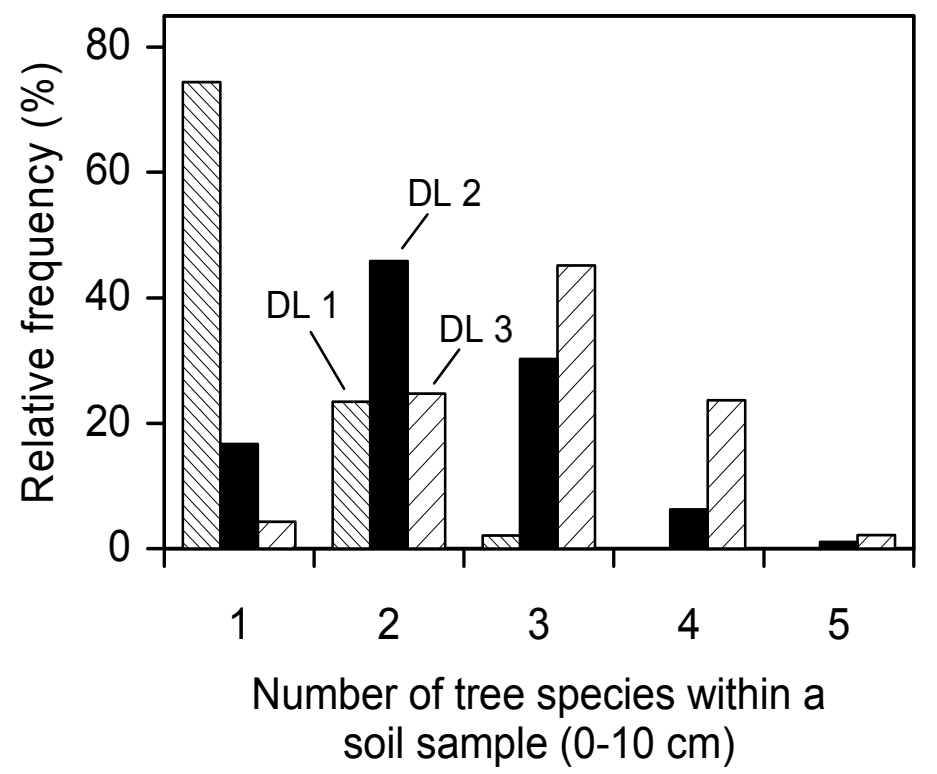

Figure 3.5 Relative frequency of soil samples $(0-10 \mathrm{~cm})$ with fine roots of 1, 2, 3, 4 or 5 tree species in plots of the three diversity levels (four plot replicates per diversity level and 24 sampling locations per plot). 


\subsection{Discussion}

\section{Fine root biomass of mixed forests - evidence for 'below-ground overyielding'?}

In our study, the profile totals of fine root biomass $(0-40 \mathrm{~cm}$ depth $)$ did not differ significantly between plots of species-poor and species-rich stands. In all plots, it ranged between $408 \mathrm{~g} \mathrm{~m}^{-2}$ (DL 1 plots) and $466 \mathrm{~g} \mathrm{~m}^{-2}$ (DL 2 plots) with the difference not being significant. These values may be close to the totals of the entire soil profile, because the lower soil horizons with a high bulk density contained an only small fine root biomass. In fact, Leuschner \& Hertel (2003) found a mean fine root biomass total of $482 \mathrm{~g} \mathrm{~m}^{-2}$ (0 to $100 \mathrm{~cm}$ profile) for 60 broad-leaved forests in a meta-analysis for the temperate zone.

In theory, niche complementarity of the root systems of coexisting tree species could lead to a higher fine root biomass in mixed forests compared to monospecific stands of the respective tree species. For example, roots of certain tree species may penetrate into lower mineral soil layers, thereby exploring additional soil volume, or they might specialise on preferential rooting in the organic layer which may not be explored in a comparable intensity by other tree species. A higher fine root biomass in multi-species compared to monospecific stands resembles the 'overyielding' phenomenon which is observed, for example, in artificial grasslands (Hector et al. 1999; Roscher et al. 2005) when mixed cultures have a higher aboveground phytomass production than any monoculture of the constituting species. Clearly, data on fine root biomass and hay yield are not directly comparable, because only the latter refers to productivity. Nevertheless, given the large methodological problems associated with fine root production measurement, standing fine root biomass may serve as a first approximation of below-ground productivity in forests.

We are aware of only six studies including the present one, which compared fine root biomass of monospecific and mixed forests on similar soil, or patches of a forest differing in tree species diversity. While four studies compared one- and two-species stands, the study by Rewald \& Leuschner (submitted) together with the present one are the only studies which referred to species-rich stands with more than four tree species. These six studies produced controversial results with respect to 'below-ground overyielding'. Schmid (2002) found a higher, Morgan et al. (1992) a lower fine root biomass in two-species stands compared to monospecific stands, while Brandtberg et al. (2000) and Leuschner et al. (2001) observed a similar fine root mass in one- and two-species stands. The study by Rewald \& Leuschner (submitted) compared forest patches, where roots of one to four tree 
species coexisted in the soil, and provided only weak evidence of the existence of a higher fine root mass in mixed patches. By comparing monospecific stands with stands of three to five species, our study similarly found no conclusive evidence of higher root biomass in the species-rich stands.

In conclusion, not much evidence has accumulated yet for a higher fine root biomass in temperate mixed forests compared to pure stands. On the other hand, several studies found indications of a spatial segregation of the fine root systems of different species in mixed forests (e.g. Bennett et al. 2002; Bolte \& Villanueva 2006), in some cases irrespective of elevated root biomasses in mixtures. In our study, we compared the vertical distribution of fine root biomass with the exponential model of Gale \& Grigal (1987) and found very similar patterns for the overall biomass of 1-, 3- and 5-species stands, but also for the different species being present in the stands. All species showed exponents of the exponential equation ( $($ values) of 0.92 to 0.95 which indicates no systematic difference in the vertical soil exploration strategies of the species. A clear deviation from this uniform pattern was observed only in one case (Fagus in the DL 2 plots). We speculate that the specific soil conditions may have contributed to the uniform root biomass/depth relations in our study: bulk density was rather high in the clayey soil and increased with depth, thereby hindering deep root penetration. We summarize that a certain degree of belowground niche complementarity in terms of space occupation may well exist in certain mixed forests but it seems not to be a universal phenomenon. Systematic investigations in a larger number of forests differing in tree species diversity are needed to clarify the importance of niche complementarity among fine root systems and to show under which circumstances it may result in 'overyielding' in terms of fine root biomass and productivity.

\section{Horizontal fine root distribution and species overlap}

The fine root systems had a far larger horizontal extension than the corresponding tree crowns in the mixed stands. With an estimated maximum diameter of the fine root system of $20 \mathrm{~m}$ in Fagus and Carpinus, trees of these species may spread their fine roots over an area of more than $300 \mathrm{~m}^{2}$, which is roughly five times the size of the corresponding crown projection area (Kochenderfer 1973; Mou \& Jones 1995; Müller \& Wagner 2003; Johnsen et al. 2005). Rewald \& Leuschner (submitted) reported about a maximum root extension of even $30 \mathrm{~m}$ in the case of Tilia trees. For Fraxinus, Tilia and Acer, we found a gradual 
decrease in fine root density with increasing stem distance within a radius of $10 \mathrm{~m}$ or more, but not a strict stem-centered distribution pattern as it was observed, for example, in spruce forests by Bédéneau \& Auclair (1989) and Nielsen \& Mackenthun (1991). Only in the case of Carpinus and Fagus trees growing in mixed stands, fine root biomass showed a steep decrease within a $8 \mathrm{~m}$-radius around the stems. Depending on tree species, the decrease was best described either by a linear or a sigmoid equation. The Acer species showed a remarkable rooting pattern by maintaining only rather low root densities in the mixed stands which, however, extended over a large area and reached maximum stem distances of up to $20 \mathrm{~m}$.

Our data showed a high degree of root system overlap in all mixed stands, and even did so in the pure beech stands where the rare species intermingled largely with the dominant beech roots. This is in agreement with data obtained in two species beech-oak stands where both tree species were present in more than $95 \%$ of all root samples (Büttner \& Leuschner 1994; Leuschner et al. 2001). Similarly to Rewald \& Leuschner (submitted), we found no indications of a 'territoriality' of tree fine root systems in these stands as it was suggested by Schenk et al. (1999).

\section{Are there indications of root competition between adults and saplings?}

High densities of fine root biomass per soil volume could potentially lead to fierce competition between co-existing tree species and also between adult and juvenile trees. For example, Rysavy (1992) and Wagner (1999) discussed the potential role of high root densities of ash saplings for beech regeneration in mixed stands on calcareous soils. In our study, total fine root biomass (adults and saplings) exceeded $1 \mathrm{~g} \mathrm{~L}^{-1}$ in the topsoil of certain plots which could have a negative effect on sapling survival. However, tree saplings occurred in very high numbers in many plots, locally exceeding 220,000 ha ${ }^{-1}$. The most common trees in the sapling layer were Acer species which dominated even in the monospecific beech stands, but the contribution of sapling fine root biomass was low in all cases, never exceeding $1 \%$ of total fine root biomass. This indicates that root competition is not a key factor determining the success of rejuvenation in these stands. 


\section{Acknowledgments}

This study is part of the postgraduate studies program Graduiertenkolleg 1086 "The role of biodiversity for biogeochemical cycles and biotic interactions in temperate deciduous forests". The funding of this study by DFG (Deutsche Forschungsgemeinschaft) and the financial support of the RISE (Research Internships in Science and Engineering) scholarship for Nicholas T. Ryan by DAAD (Deutscher Akademischer Austauschdienst) is gratefully acknowledged. We appreciate the permission to conduct the study in the Hainich National Park and thank all participants of the Graduiertenkolleg for excellent teamwork. Data of forest stand parameters were kindly provided by Mascha Brauns, Karl Maximilian Daenner, Anja Guckland, Andreas Mölder and Inga Schmidt. 


\subsection{References}

Bauhus J, Khanna PK, Menden N (2000) Aboveground and belowground interactions in mixed plantations of Eucalyptus globulus and Acacia mearnsii. Canadian Journal of Forest Research 30:1886-1894

Bédéneau M, Auclair D (1989) The study of tree fine root distribution and dynamics using a combined trench and observation window method. Annales des Sciences Forestieres 46:283-290

Bennett JN, Andrew B, Prescott CE (2002) Vertical fine root distributions of western redcedar, western hemlock, and salal in old-growth cedar-hemlock forests on northern Vancouver Island. Canadian Journal of Forest Research 32:1208-1216

Bolte A, Villanueva I (2006) Interspecific competition impacts on the morphology and distribution of fine roots in European beech (Fagus sylvatica L.) and Norway spruce (Picea abies (L.) Karst.). European Journal of Forest Research 125:15-26

Brandtberg PO, Lundkvist H, Bengtsson J (2000) Changes in forest-floor chemistry caused by a birch admixture in Norway spruce stands. Forest Ecology and Management 130:253-264

Büttner V, Leuschner C (1994) Spatial and temporal patterns of fine root abundance in a mixed oak-beech forest. Forest Ecology and Management 70:11-21

Casper BB, Jackson RB (1997) Plant competition underground. Annual Review of Ecology and Systematics 28:545-570

Gale MR, Grigal DF (1987) Vertical root distributions of northern tree species in relation to successional status. Canadian Journal of Forest Research 17:829-834

Guckland A, Brauns M, Flessa H, Thomas FM, Leuschner C (2008) Acidity, nutrient stocks and organic matter content in soils of a temperate deciduous forest with different abundance of European beech (Fagus sylvatica L.). Journal of Plant Nutrition and Soil Science, in press

Hector A, Schmid B, Beierkuhnlein C, Caldeira MC, Diemer M, Dimitrakopoulos PG, Finn JA, Freitas H, Giller PS, Good J, Harris R, Högberg P, Huss-Danell K, Joshi J, Jumpponen A, Körner C, Leadley PW, Loreau M, Minns A, Mulder CPH, O'Donovan G, Otway SJ, Pereira JS, Prinz A, Read DJ, Scherer-Lorenzen M, Schulze ED, Siamantziouras ASD, Spehn EM, Terry AC, Troumbis AY, Woodward FI, Yachi S, Lawton JH (1999) Plant diversity and productivity experiments in European grasslands. Science 286:1123-1127

Hendriks CMA, Bianchi FJJA (1995) Root density and root biomass in pure and mixed forest stands of Douglas-fir and Beech. Netherlands Journal of Agricultural Science 43:321-331 
Hertel D (1999) Das Feinwurzelsystem von Rein- und Mischbeständen der Rotbuche: Struktur, Dynamik und interspezifische Konkurrenz. Dissertationes Botanicae 317. Gebrüder Borntraeger, Berlin, Stuttgart

Hölscher D, Hertel D, Leuschner C, Hottkowitz M (2002) Tree species diversity and soil patchiness in a temperate broad-leaved forest with limited rooting space. Flora 197:118-125

Hooper DU, Vitousek PM (1997) The effects of plant composition and diversity on ecosystem processes. Science 277:1302-1305

Johnsen K, Maier C, Kress L (2005) Quantifying root lateral distribution and turnover using pine trees with a distinct stable carbon isotope signature. Functional Ecology 19:81-87

Kochenderfer JN (1973) Root distribution under some forest types native to West-Virginia. Ecology 54:445-448

Korn S (2004) Experimentelle Untersuchung der Wasseraufnahme und der hydraulischen Eigenschaften des Wurzelsystems von sechs heimischen Baumarten. PhD thesis. University of Goettingen. http://webdoc.sub.gwdg.de/diss/2004/korn

Leuschner C, Hertel D, Coners H, Büttner V (2001) Root competition between beech and oak: a hypothesis. Oecologia 126:276-284

Leuschner C, Hertel D (2003) Fine root biomass of temperate forests in relation to soil acidity and fertility, climate, age and species. Progress in Botany 64:405-438

Leuschner C, Jungkunst HF, Fleck S (2008) Studying the functional role of tree diversity in forests: the pros and cons of synthetic stands and across-site comparisons in established forests. Basic and Applied Ecology, in press

Loreau M, Hector A (2001) Partitioning selection and complementarity in biodiversity experiments. Nature 412:72-76

Mölder A, Bernhardt-Römermann M, Schmidt W (2006) Forest ecosystem research in Hainich National Park (Thuringia): First results on flora and vegetation in stands with contrasting tree species diversity. Waldoekologie online 3:83-99

Mölder A, Bernhardt-Römermann M, Schmidt W (2008) Vielfältige Baumschicht reichhaltige Verjüngung? Zur Naturverjüngung von artenreichen Laubwäldern im Nationalpark Hainich. Allgemeine Forst und Jagdzeitung, in press

Morgan JL, Campbell JM, Malcolm DC (1992) Nitrogen relations of mixed-species stands on oligotrophic soils. In: Cannell MGR, Malcolm DC, Robertson PA (eds) The ecology of mixed-species stands of trees. Blackwell, London, pp 65-85

Mou P, Jones RH (1995) Spatial distribution of roots in Sweetgum and Loblolly Pine monocultures and relations with above-ground biomass and soil nutrients. Functional Ecology 9:689-699

Müller KH, Wagner S (2003) Fine root dynamics in gaps of Norway spruce stands in the German Ore Mountains. Forestry 76:149-158 
Nielsen CCN, Mackenthun G (1991) Spatial variation of fine root biomass intensity in forest soils related to stand density - a numerical-method estimating the rootintensity-bell around single trees. Allgemeine Forst und Jagdzeitung 162:112-119

Persson H (1978) Root dynamics in a young Scots pine stand in Central Sweden. Oikos 30:508-519

Roscher C, Temperton VM, Scherer-Lorenzen M, Schmitz M, Schumacher J, Schmid B, Buchmann N, Weisser WW, Schulze ED (2005) Overyielding in experimental grassland communities - irrespective of species pool or spatial scale. Ecology Letters 8 (4):419-429

Rysavy T (1992) Vereschung - Ursachen und Möglichkeiten ihrer Vermeidung. PhD thesis. Göttingen, University of Goettingen

Schenk HJ, Callaway RM, Mahall BE (1999) Spatial root segregation: Are plants territorial? Advances in Ecological Research 28:145-180

Scherer-Lorenzen M, Schulze ED, Don A, Schumacher J, Weller E (2007) Exploring the functional significance of forest diversity: A new long-term experiment with temperate tree species (BIOTREE). Perspectives in Plant Ecology Evolution and Systematics 9:53-70

Schmid I (2002) The influence of soil type and interspecific competition on the fine root system of Norway spruce and European beech. Basic and Applied Ecology 3:339346

Schmid I, Kazda M (2002) Root distribution of Norway spruce in monospecific and mixed stands on different soils. Forest Ecology and Management 159:37-47

Spehn EM, Joshi J, Schmid B, Diemer M, Körner C (2000) Above-ground resource use increases with plant species richness in experimental grassland ecosystems. Functional Ecology 14:326-337

Stone EL, Kalisz PJ (1991) On the maximum extent of tree roots. Forest Ecology and Management 46:59-102

Tilman D, Wedin D, Knops J (1996) Productivity and sustainability influenced by biodiversity in grassland ecosystems. Nature 379:718-720

Tilman D, Lehman CL, Thomson KT (1997) Plant diversity and ecosystem productivity: Theoretical considerations. Proceedings of the National Academy of Sciences of the United States of America 94:1857-1861

Wagner S (1999) Ökologische Untersuchungen zur Initialphase der Naturverjüngung in Eschen-Buchen-Mischbeständen. Sauerländer's Verlag, Frankfurt am Main 
CHAPTER

4

Is the root system of species-rich forests more productive and more resilient after disturbance than that of monocultures? 


\subsection{Abstract}

In contrast to studies on above-ground processes, the effect of species diversity on belowground productivity and fine root resilience after disturbance is still poorly studied in forests. In 12 old-growth broad-leaved forest stands, we tested the hypotheses that (i) the productivity and the resilience of the fine root system (root diameter $<2 \mathrm{~mm}$ ) increase with increasing tree species diversity, and that (ii) the seasonality of fine root biomass and necromass is more pronounced in pure than in tree species-rich stands as a consequence of non-synchronous root biomass peaks of the different species. We investigated stands with 1,3 , and 5 dominant tree species growing under similar soil and climate conditions for changes in fine root biomass and necromass during a 12-month period and estimated fine root productivity with two independent approaches (ingrowth core, sequential coring).

According to the analysis of 360 ingrowth cores, fine root growth into the root-free soil increased with tree species diversity from $72 \mathrm{~g} \mathrm{~m}^{-2} \mathrm{yr}^{-1}$ in the monospecific plots to $166 \mathrm{~g}$ $\mathrm{m}^{-2} \mathrm{yr}^{-1}$ in the 5-species plots indicating a more rapid recovery of the root system after soil disturbance in the species-rich stands. Fine root productivity as approximated by the sequential coring data also indicated a roughly threefold increase from the monospecific to the 5-species stand. We found no indication of a more pronounced seasonality of fine root mass in species-poor as compared to species-rich stands. We conclude that species identification on the fine root level, as conducted here, may open new perspectives on tree species effects on root system dynamics. Our study produced first evidence in support of the hypothesis that more diverse forest stands are more resilient after soil disturbance, and perhaps more productive, in their fine root system than species-poor forests. 


\subsection{Introduction}

Only recently, research on the functions of biodiversity has shifted its focus from grassland and herbaceous communities to forests (Scherer-Lorenzen et al. 2007). Experiments in synthetic grasslands have shown that increasing plant species diversity can enhance aboveground productivity, may increase the resilience of the community after disturbance, and can affect other functions of the ecosystem (Tilman et al. 1996, 1997, 2001; Peterson 1998; Hector et al. 1999; Tilman 1999; Chapin et al. 2000; Hector 2001; Loreau \& Hector 2001). Much less is known about the functions of tree diversity in forests. Most of the existing studies on diversity effects in forests dealt with monocultures and two-species mixtures (Kelty 1992; Bartelink \& Olsthoorn 1999); these trials produced contradictory results (Pretzsch 2005). In addition, most of these studies investigated above-ground responses, while much less is known about effects of tree diversity on below-ground processes such as root growth and turnover.

Although tree fine roots $(<2 \mathrm{~mm}$ in diameter $)$ represent only a minor part of total tree biomass, it has been suggested that they can consume up to $30-50 \%$ of the annual primary production (Ruess et al. 1996; Vogt et al. 1996; Xiao et al. 2003). Fine roots are not only responsible for water and nutrients uptake, but they are also an important component of the forest carbon cycle (e.g. DeAngelis et al. 1981, Fitter 1996). In the vast majority of studies in mixed forests, fine roots have been investigated without species determination, but the ability to distinguish between species is crucial for detecting tree diversity and tree species effects in the fine root systems of forests. To our knowledge, there exist only a few studies in mixed forests that used a determination key for distinguishing fine roots of different tree species (Hertel 1999; Hölscher et al. 2002; Korn 2004).

Fine root productivity can be measured with different methods, but the results depend strongly on the employed technique with lower values estimated with ingrowth cores and higher values calculated with sequential coring or minirhizotron approaches (McClaugherty et al. 1982; Nadelhoffer \& Raich 1992; Makkonen \& Helmisaari 1999; Hertel \& Leuschner 2002). Fine root growth into root-free ingrowth cores has frequently been used as a simple method to estimate fine root production in forests (e.g. Persson 1979, 1983; Vogt et al. 1998, Makkonen \& Helmisaari 1999; Jentschke et al. 2001). However, the manipulation of growth conditions (e.g. root injury during installation, no competition processes, disturbed soil) may lead to strongly biased results on root productivity. Therefore, fine root growth into the ingrowth cores may be a more accurate estimate of the root recolonisation potential after soil 
disturbance than for fine root production under ambient soil conditions. Another technique that is often used for root production estimates are minirhizotrons (e.g. Andren et al. 1991; Majdi 1996; Johnson et al. 2001). This method is considered to track fine root dynamics more reliably than soil cores (Trumbore \& Gaudinski 2003), but it does not allow species determination in mixed stands. Sequential coring is commonly used, but often a problematic method for estimating fine root productivity. It additionally provides data about seasonal changes in the fine root mass. Furthermore, this method allows species identification at the fine root level (Hölscher et al. 2002); and thus has certain advantages when mixed stands are studied.

This study investigated fine root biomass and its dynamics in temperate broad-leaved forests differing in tree species diversity. By comparing old-growth forests with 1, 3, and 5 dominant tree species, we aimed at detecting effects of tree species diversity or tree species identity on fine root biomass, necromass, root mass phenology and root productivity. We employed two different approaches for estimating fine root productivity, the ingrowth core and the sequential coring approach, which both enabled species identification on the basis of fine roots. The ingrowth core data were interpreted as a measure of root system recovery after soil disturbance.

By measuring the seasonality in fine root biomass and necromass in each one plot with 1, 3, and 5 species and by quantifying fine root growth dynamics (in each four plots), we tested the hypotheses that (i) seasonal changes in fine root mass are more pronounced in pure than in tree species-rich stands as a consequence of non-synchronous root mass peaks of the different tree species during the growing season, and that (ii) productivity and resilience of the fine root system (i.e. recovery after disturbance) increase with increasing tree species diversity.

\subsection{Materials and methods}

\section{Study site}

The Hainich National Park in Thuringia (Germany) protects one of the largest continuous broad-leaved forests in Central Europe. The forest is mainly dominated by European beech (Fagus sylvatica L.), but in some parts, up to 14 tree species coexist which is a consequence of former management practice. We conducted the study in mature deciduous broad-leaved forest stands in the north-east of the National Park. In total, 12 study plots (50 m x $50 \mathrm{~m}$ ) were selected that cover a gradient from low to high tree species diversity. Plots of diversity level 1 
(DL 1) contained mainly Fagus sylvatica ( $>95 \%$ of total basal area). Plots of diversity level 2 (DL 2) were built by Fagus s., Tilia sp. (T. cordata Mill. and T. platyphyllos Scop.) and Fraxinus excelsior L. Forest stands in plots of diversity level 3 (DL 3) were formed by Fagus s., Tilia sp., Fraxinus e., Carpinus betulus L. and Acer sp. (A. pseudoplatanus L. and A. platanoides L.). Additional rare tree species were Acer campestre L., Prunus avium L., Quercus robur L., Q. petraea Liebl. and Ulmus glabra L. Four study plots per diversity level were selected as replicates.

The selected plots represented mature forest stands with a closed canopy. Mean tree age was about 100 years; however, the Fagus trees in the DL 1 plots were older (146 yr on average). The basal areas were similar between plots, but stem densities were somewhat higher on the plots of DL 2 (Table 4.1). Canopy height ranged from 26 meters in plots of DL 3 to 38 meters in plots of DL 1. The Shannon index increased from 0.2 in the almost monospecific beech plots to 1.8 in the plots of DL 3 . Annual mean air temperature was about $7.5^{\circ} \mathrm{C}$ and annual precipitation averaged at $670 \mathrm{~mm}$ (data of the nearby weather station Weberstedt/Hainich). Mean fine root biomass $(0-20 \mathrm{~cm})$ ranged from of $280 \mathrm{~g} \mathrm{~m}^{-2}$ in the plots of DL 1 to $366 \mathrm{~g} \mathrm{~m}^{-2}$ in the plots of DL 2 and did not differ significantly between the three different diversity levels (Meinen et al. submitted). The parent material of all plots was Triassic limestone covered by loess (minimum depth of $60 \mathrm{~cm}$ ). The soil type of the plots was a Luvisol (WRB 2006 taxonomy) with stagnic properties in spring and winter and a dry period in summer (Figure 4.1). In the foliation period from mid-May to November, the soil temperature at $5 \mathrm{~cm}$ soil depth was $1{ }^{\circ} \mathrm{C}$ higher at the plots of DL 3 than at the DL 1 plots. The soil texture was rich in silt $(74 \%)$, but poor in sand $(<5 \%)$ (Guckland et al. 2008). The $\mathrm{pH}\left(\mathrm{H}_{2} \mathrm{O}\right)$ value in $0-10 \mathrm{~cm}$ soil depth ranged from 4.6 in the plots of DL 1 to 6.7 in the plots of DL 3 . Hence, base saturation was particularly low in the DL 1 plots. A detailed description of the selection criteria for the study plots is given in Leuschner et al. (2008). 


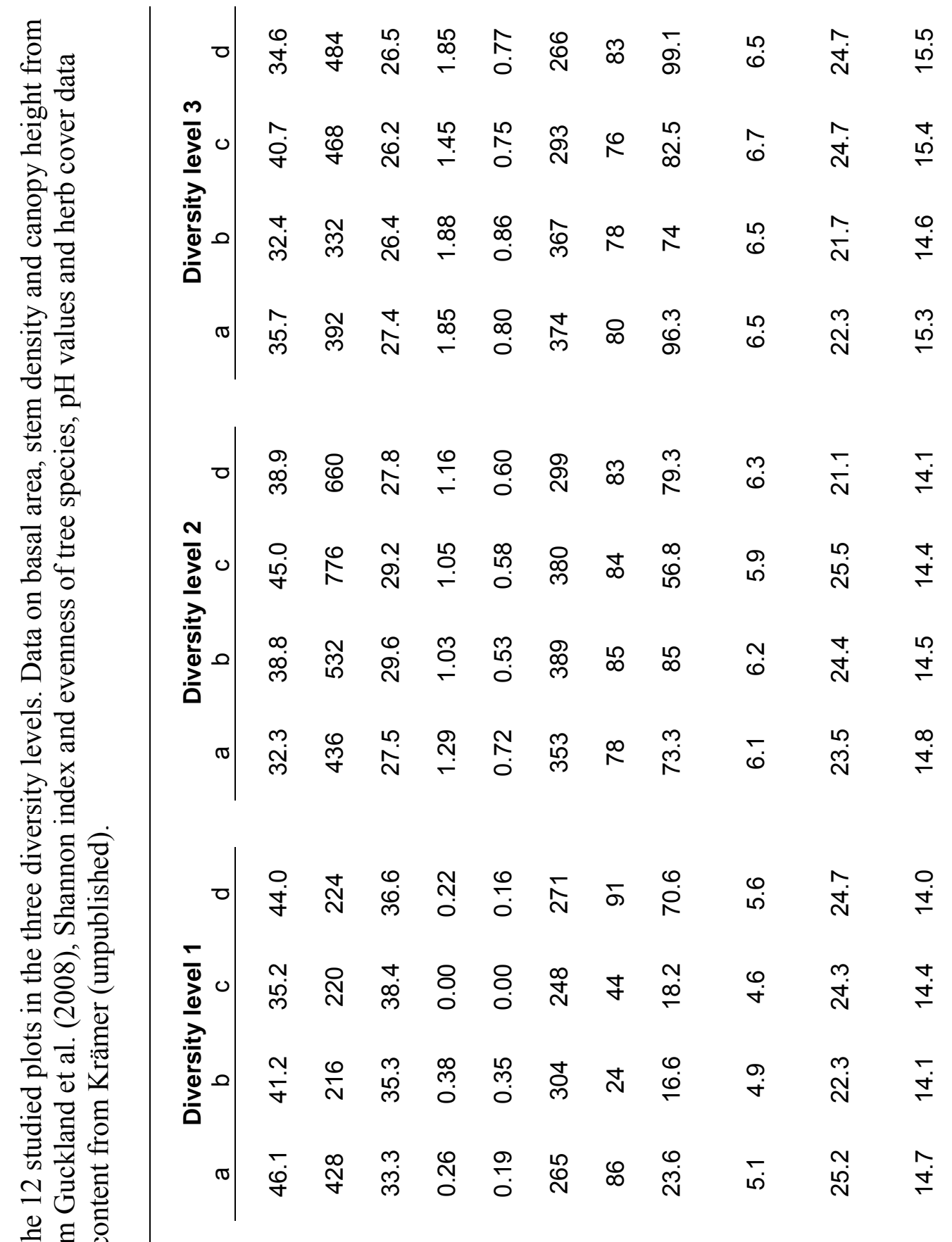

$\exists$ ఫ

$\exists \leftrightarrows \bar{s}$

응

氜

诺

흥 :

気

के

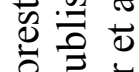

它壳弯

잉

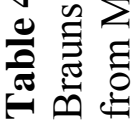




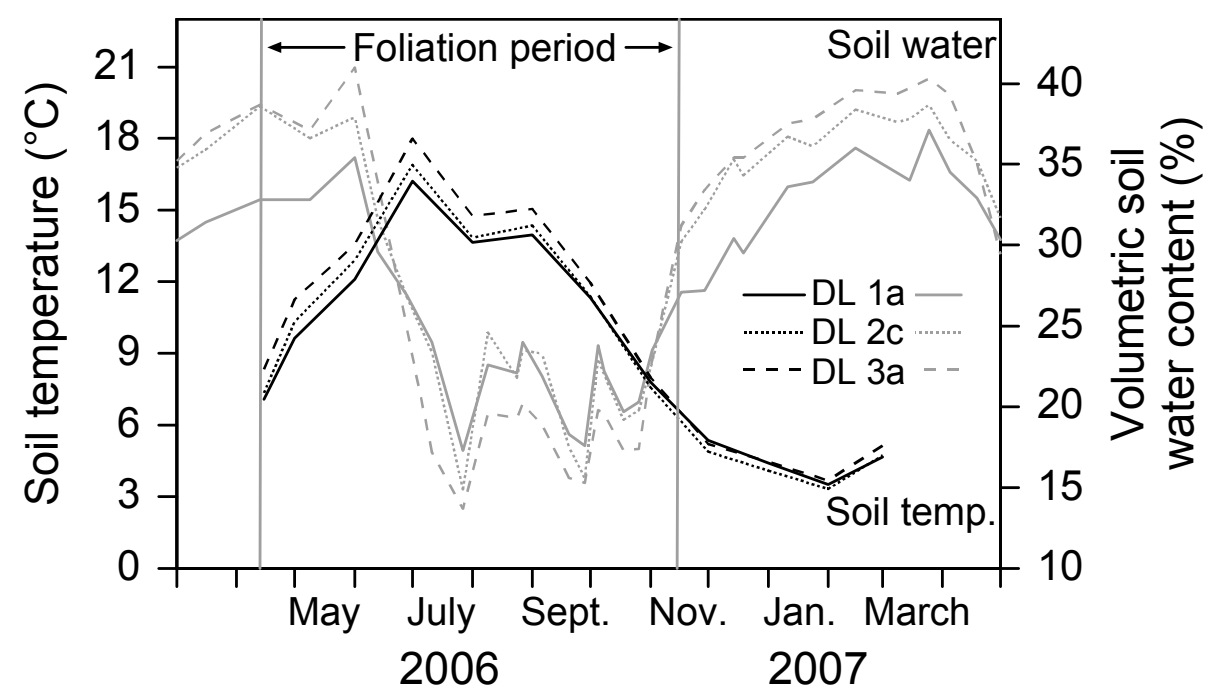

Figure 4.1 Seasonal course of soil temperature in $5 \mathrm{~cm}$ soil depth and volumetric soil water content in $10 \mathrm{~cm}$ soil depth from April 2006 until February 2007 in the plots DL 1a, DL 2c and DL 3a. Given are daily means of nine temperature logger stations and means of six volumetric soil water content (Sentek) readings per plot (every second week).

\section{Fine root sampling}

To inventory the standing fine root biomass at the 12 plots of the three diversity levels, we randomly selected 24 sampling locations per plot. The minimum distance between the sampling points was $1 \mathrm{~m}$. Soil samples were taken in the year 2005 and 2006 from the organic litter layer down to $20 \mathrm{~cm}$ soil depth on 12 study plots. We divided each soil core in two subsamples (organic layer plus $0-10 \mathrm{~cm}$ mineral soil and $10-20 \mathrm{~cm}$ ). To extract the fine roots from the soil, the samples were soaked shortly in water and the fine roots were washed out using a sieve (mesh size $0.25 \mathrm{~mm}$ ). Fine roots longer than $10 \mathrm{~mm}$ were picked out by hand with a pair of tweezers and separated under a stereomicroscope into the live and the dead fraction and were sorted according to species. Live and dead fine roots were distinguished by root elasticity, colour, and the degree of the cohesion of stele and periderm (Persson 1978; Leuschner et al. 2001). Root death was indicated by a complete loss of stele and cortex, a dark cortex or stele, or a white, but non-turgid stele. Morphological characteristics like the surface structure, colour of the periderm, type of mycorrhizal infection and ramification pattern were applied for species identification according to an identification key established for the occurring tree species by Hertel (1999), Hölscher et al. (2002) and Korn (2004). Grass and herb roots were distinguished from tree roots by their smaller diameter, non-lignified structure 
and lighter colour. The sorted fine root biomass and necromass was dried at $70{ }^{\circ} \mathrm{C}$ for $48 \mathrm{~h}$ and weighed. Fine root mass was expressed as root abundance (unit: $\mathrm{g} \mathrm{m}^{-2}$ ).

In order to record seasonal changes in fine root bio- and necromass, a sequential coring campaign was conducted from April 2006 until January 2007. Due to the time consuming work of fine root sorting, we had to focus on one plot per diversity level i.e. three plots in total (DL 1a, DL 2c and DL 3a). Hence, statistical analyses of these data sets were not possible. We took cores in spring (April 21, 2006), summer (June 28, 2006), autumn (September 27, 2006) and winter (January 15, 2007). This sampling design was consistent to the inventory design; the processing of the fine roots was done as described above. Additionally, fine root necromass was included in the analysis. The fine root fraction $>10$ $\mathrm{mm}$ represents the major part of the living fine root mass, but dead fine roots are often smaller due to progressive decay. A method introduced by van Praag et al. (1988) and modified by Hertel (1999) was applied to one sixth of all samples after extraction of fine roots larger than $10 \mathrm{~mm}$ in length. The soil residue were evenly distributed on a large sheet of filter paper (730 $\mathrm{cm}^{2}$ ) subdivided into 36 squares. Six of these squares were randomly selected and the soil material was analysed for even smallest fine root fragments under the stereomicroscope. The dry mass of small dead rootlets was extrapolated to the entire sample by means of the ratio of small dead rootlets to large dead roots ( $>10 \mathrm{~mm}$ length) that was established in a subsample. Fine root production was estimated with the 'minimum-maximum method' by using the sequential coring data (Persson 1978; McClaugherty et al. 1982). This method equates the difference between the minimum and the maximum of total fine root mass (sum of fine root bio- and necromass) with the fine root production in the measured period. The coring was conducted on four occasions within an 8 month period by assuming that no root mass peak occurred between the sampling dates. In principal, only significant differences between seasonal root mass peaks and lows should be considered when applying the minimummaximum approach. Significant minimum-maximum differences were found only in a minority of cases (about 1/3). We assumed that a zero production of beech roots in the DL 1 plot is an unrealistic result and therefore we accepted the non-significant differences in root mass in the DL 1 plot as well. For other tree species in the mixed DL 2 and DL 3 plots, a zero production was similarly unlikely; thus we calculated the production with the non-significant differences in these cases as well. Clearly, this procedure can lead to very rough estimates of fine root production only.

Ingrowth cores were applied as a second method for estimating fine root productivity in the 12 plots (Powell \& Day 1991; Majdi 1996). This approach quantifies the ingrowth of fine 
roots into root-free soil and this represents a measure of the recovery of the fine root system after disturbance. In May 2005, each 30 ingrowth cores per plot were installed at random locations and resampled after 24 month in May 2007. We interpreted the regrowth rate (expressed as $\mathrm{g} \mathrm{m}^{-2} \mathrm{yr}^{-1}$ ) as an estimate of fine root system resilience since it quantifies the speed at which the fine roots in the plots re-explored empty soil volume. Soil cores were extracted from the topsoil down to $20 \mathrm{~cm}$ depth with a sharp soil corer (diameter $3.5 \mathrm{~cm}$ ), the soil material was cleaned by hand from all macroscopically visible live and dead rootlets and the cores were replaced into the hole. Minimum distance between two ingrowth cores was 1 m. The edges were marked accurately at the soil surface. The structure and density of the extracted soil was conserved as much as possible. To minimize soil disturbance no mesh bags were used. We observed fine root growth in a two-month interval by harvesting single ingrowth cores to determine the beginning of fine root growth. This data indicates that fine root growth started in the bulk of the ingrowth cores around May 2006, i.e. after a 12-month lag period. We harvested all cores in May 2007 and fine root biomass in the cores was quantified as described above. We calculated the fine root recovery rate $\left(\mathrm{yr}^{-1}\right)$ in the ingrowth cores by relating annual fine root regrowth into the ingrowth cores to standing fine root biomass in undisturbed soil in the plots.

In all plots, mean daily soil temperature in $5 \mathrm{~cm}$ soil depth was monitored by nine temperature data loggers (DS 1921 Thermochron iButtons, Fa. Dallas Semiconductor, USA) per plot.

\section{Statistical analyses}

The Shapiro and Wilk test was used to analyse all data sets for normal distribution. Fine root biomass data sets showed non-normal distributions and remained skewed even after log or root transformation. Therefore, the data sets were tested by Kruskal-Wallis single factor analysis of variance followed by a non-parametric Mann-Whitney two sample U-test to detect significant differences in total fine root biomass between diversity levels. The ingrowth core data sets showed normal distribution and were tested for significant differences between diversity levels by an ANOVA procedure followed by a Scheffé $f$-test. All analyses were accomplished at a $5 \%$ rejection level. The software package SAS, version 8.2 (SAS Institute Inc., Cary, NC, USA) was used for the analyses.

The dependence of tree and herb fine root regrowth on Shannon-index and evenness of the tree species, total fine root biomass of the stands, base saturation, $\mathrm{pH}$ of the soil, soil water 
content and soil temperature was analysed by single factor linear regression analyses (software package Xact version 8.03, SciLab, Hamburg, Germany).

\subsection{Results}

\section{Seasonal variability of fine root bio- and necromass}

The seasonal variability of fine root biomass in the three studied plots DL 1a, DL 2c, and DL 3a was low in the period of April 2006 to January 2007. The seasonal biomass maxima and minima differed by not more than $20 \%$ in this 9-month period if the stands totals (all species) were considered (Figure 4.2). Biomass minima were recorded in all plots in April 2006, maxima in June 2006 (DL 2c and DL 3a) or in January 2007 (DL 1a). Mean fine root biomass of the stands was higher in the two mixed stands (DL 2c and DL 3a: $370 \mathrm{~g} \mathrm{~m}^{-2}$ ) than in the monospecific DL 1a plot $\left(265 \mathrm{~g} \mathrm{~m}^{-2}\right)$ in the period of the study. Our data indicate that the different species in the two mixed stands differed in their biomass seasonality with asynchronous occurrence of maxima and minima. For example, fine root biomass of Acer and Carpinus tended to be highest in April in the DL 3a plot, while Tilia reached its peak in June, Fagus in September, and Fraxinus in January. However, most of the seasonal differences were not significant but more tendencies.

In general, seasonality was more pronounced in fine root necromass than in fine root biomass. Seasonal minima and maxima of total fine root necromass differed by about $40 \%$ in plot DL 1a, but by a factor of 3.6 in plot DL 2c. In all plots, fine root necromass was significantly lower in January 2007 than at earlier sampling occasions. In the two mixed stands, the necromass of the species and also of the whole stand was highest in June and lowest in January. This indicates that seasonal minima and maxima occurred simultaneously in the plots of DL 2c and DL 3a. In contrast, in the DL 1a plot, the fine root necromass of Fagus was highest in April and significantly lower in June and January. 
Fine root biomass

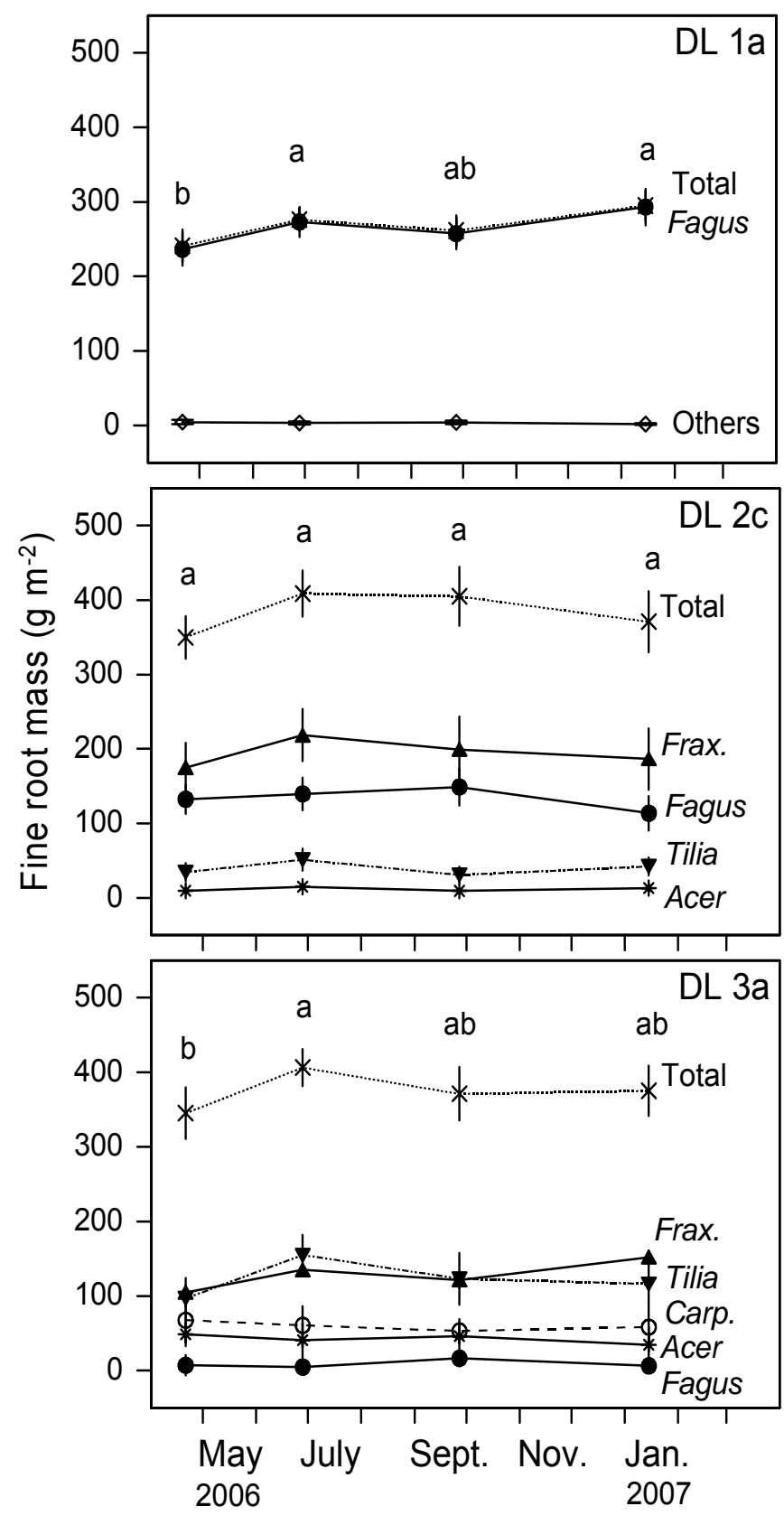

Fine root necromass
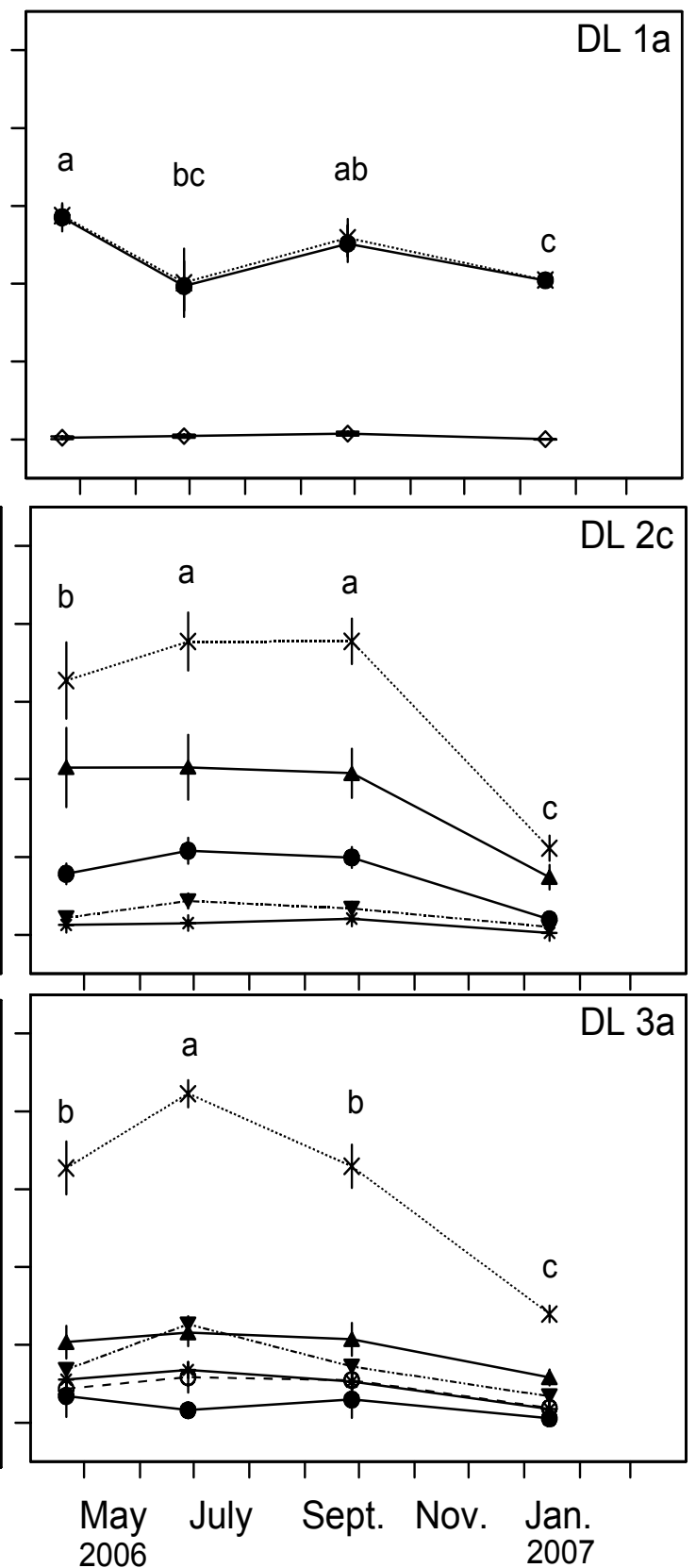

Figure 4.2 Seasonal variation in fine root biomass and fine root necromass at $0-20 \mathrm{~cm}$ soil depth in the plots DL 1a, DL $2 \mathrm{c}$ and DL 3a. Given are means ( $\pm 1 \mathrm{SE})$ of profile totals and of single tree species from 24 sampling locations per plot on four sampling dates (April 21, 2006, June 28, 2006, September 27, 2006, January 15, 2007). Different letters indicate significant differences of total fine root biomass between sampling dates $(p<0.05)$. 


\section{Fine root production}

Fine root production as approximated with the sequential coring approach in the period April 2006 to January 2007 increased markedly with increasing tree species diversity, ranging from $186 \mathrm{~g} \mathrm{~m}^{-2} \mathrm{y}^{-1}$ in the plot DL 1a to $564 \mathrm{~g} \mathrm{~m}^{-2} \mathrm{yr}^{-1}$ in the DL 3a plot (Table 4.2). In the mixed stands, $60-71 \%$ of total annual fine root production occurred in the uppermost soil layer, while in the DL 1a plot, $54 \%$ of the estimated total annual fine root production took place in 10-20 cm soil depth. In the plot DL 2c, Fraxinus $\left(259 \mathrm{~g} \mathrm{~m}^{-2} \mathrm{yr}^{-1}\right)$ was the most productive species in the entire soil profile followed by Fagus $\left(154 \mathrm{~g} \mathrm{~m}^{-2} \mathrm{yr}^{-1}\right)$; both species accounted for $82 \%$ of the total fine root production in this plot. In the plot DL 3a, total annual fine root production was mainly composed by contributions from Tilia (31\%), Acer (21\%) and Fraxinus (18\%). Herbs had only a minor part in fine root production with $3-11 \mathrm{~g} \mathrm{~m}^{-2} \mathrm{yr}^{-1}$ in all plots.

Table 4.2 Annual fine root production in 0-10, 10-20 and 0-20 cm soil depth as calculated from sequential coring data using the minimum-maximum approach for DL 1a, DL $2 \mathrm{c}$, and DL 3a plots. Given are the differences between maximum and minimum fine root mass (bioplus necromass) from four sampling occasions (April 21, 2006, June 28, 2006, September 27, 2006 , January 15,2007 ) for the occurring tree species and the stand totals. 'Other species' refers to annual fine root production of the rare species Acer campestre, Prunus avium, Ulmus glabra, Quercus petraea and Q. robur.

Annual fine root production $\left(\mathrm{g} \mathrm{m}^{-2} \mathrm{yr}^{-1}\right)$

\begin{tabular}{|c|c|c|c|c|c|c|c|c|c|}
\hline $\begin{array}{l}\text { Diversity } \\
\text { level }\end{array}$ & $\begin{array}{l}\text { Depth } \\
(\mathrm{cm})\end{array}$ & $\begin{array}{c}\text { Fagus } \\
\text { sylvatica }\end{array}$ & $\begin{array}{l}\text { Fraxinus } \\
\text { excelsior }\end{array}$ & $\begin{array}{l}\text { Tilia } \\
\text { sp. }\end{array}$ & $\begin{array}{l}\text { Acer } \\
\text { sp. }\end{array}$ & $\begin{array}{c}\text { Carpinus } \\
\text { betulus }\end{array}$ & $\begin{array}{c}\text { Other } \\
\text { species }\end{array}$ & Herbs & $\begin{array}{l}\text { Stand } \\
\text { total }\end{array}$ \\
\hline \multirow[t]{3}{*}{ DL 1a } & $0-10$ & 85.2 & & & & & & 8.3 & \\
\hline & $10-20$ & 101.0 & & & & & & & \\
\hline & $0-20$ & 186.2 & & & & & & & 186.2 \\
\hline \multirow[t]{3}{*}{ DL 2c } & $0-10$ & 98.2 & 201.7 & 39.1 & 21.4 & & & 3.3 & \\
\hline & $10-20$ & 55.5 & 57.0 & 22.9 & 8.3 & & & & \\
\hline & $0-20$ & 153.7 & 258.7 & 62.0 & 29.7 & & & & 504.1 \\
\hline \multirow[t]{3}{*}{ DL 3a } & $0-10$ & 40.9 & 62.4 & 99.5 & 76.3 & 33.2 & 27.2 & 11.3 & \\
\hline & $10-20$ & 23.9 & 37.5 & 75.4 & 39.7 & 30.1 & 17.7 & & \\
\hline & $0-20$ & 64.8 & 99.9 & 174.9 & 116.0 & 63.3 & 44.9 & & 563.8 \\
\hline
\end{tabular}




\section{Fine root growth into root-free soil cores}

The fine root biomass of trees and herbs grown into root-free soil increased with increasing tree species diversity (Figure 4.3). The regrowth rate increased significantly from $72 \mathrm{~g} \mathrm{~m}^{-2} \mathrm{yr}^{-1}$ in the plots of DL 1 to $166 \mathrm{~g} \mathrm{~m}^{-2} \mathrm{yr}^{-1}$ in the plots of DL 3 (Figure $4.3 \mathrm{~A}$ ). The ingrowth cores in the DL 2 plots were mainly colonised by Fagus (48 \% of total) and Fraxinus (41\%) roots, while five tree species contributed to the ingrowth in the plots of DL 3. In these species-rich stands, $38 \%$ of total annual fine root ingrowth was identified as Tilia roots, followed by Fraxinus (24\%) and Carpinus (14\%). Annual fine root ingrowth of herbs increased from $2 \mathrm{~g}$ $\mathrm{m}^{-2} \mathrm{yr}^{-1}$ in the DL 1 plots to $9 \mathrm{~g} \mathrm{~m}^{-2} \mathrm{yr}^{-1}$ in the DL 3 plots (Figure $4.3 \mathrm{~B}$ ). Although annual herb root ingrowth was 4.5 times higher in plots of DL 3 than in DL 1 plots, this difference was only significant at $\mathrm{p}<0.1$ due to the large variation among the plots of a diversity level.

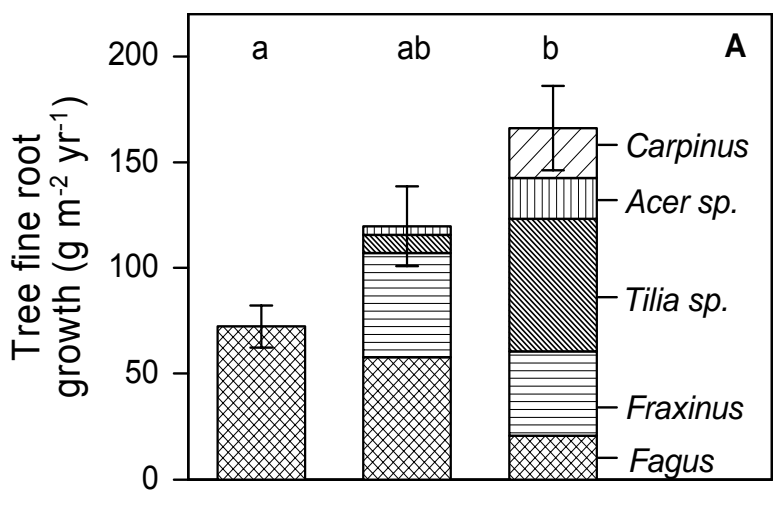

DL $1 \quad$ DL $2 \quad$ DL 3

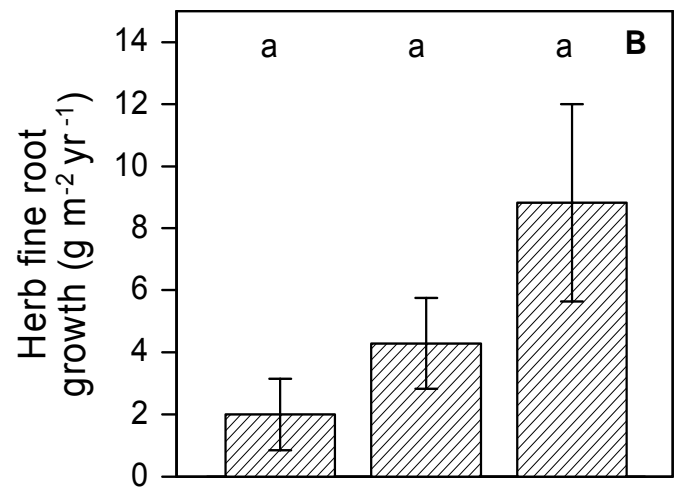

DL $1 \quad$ DL $2 \quad$ DL 3

Figure 4.3 Fine root growth of trees (A) and herbs (B) into root-free soil estimated with ingrowth cores in 12 plots of the three diversity levels. Given are means $( \pm 1 \mathrm{SE}$ ) for profile totals $(0-20 \mathrm{~cm})$ and tree species contribution in the four plot replicates per diversity level (approx. 20-30 sampling locations per plot). Different letters indicate significant differences between plots of the three diversity levels $(n=4)$ at $p<0.05$. Note different scales for tree and herb fine root growth.

The fine root recovery rate (fine root growth into ingrowth cores expressed per unit standing fine root biomass) of the stands significantly increased from the $0.26 \mathrm{yr}^{-1}$ in plots of DL 1 to $0.51 \mathrm{yr}^{-1}$ in the plots of DL 3 (Table 4.3). This pattern was also found for the recovery rate of Fagus roots which increased with increasing tree species diversity, i.e. from the monospecific to the mixed stands. The recovery rate of Fraxinus did not differ between plots of DL 2 and DL 3, while for Tilia, a significant increase from $0.16 \mathrm{yr}^{-1}$ (DL 2 plots) to $0.63 \mathrm{yr}^{-1}$ (DL 3 plots) was found. The fine root recovery rate of Acer also increased from the DL 2 plots to the DL 3 plots. 
Table 4.3 Fine root recovery rate in $0-20 \mathrm{~cm}$ soil depth as estimated from the ingrowth core data on root ingrowth per time method and the standing fine root biomass data of the plots (means $\pm 1 \mathrm{SE}$ ). Different letters indicate significant differences between species (Greek letters) or diversity levels (Latin letters) at $\mathrm{p}<0.05$.

\begin{tabular}{|c|c|c|c|c|c|c|c|}
\hline \multirow[b]{2}{*}{$\begin{array}{l}\text { Diversity } \\
\text { level }\end{array}$} & \multirow[b]{2}{*}{$\begin{array}{l}\text { Depth } \\
\text { (cm) }\end{array}$} & \multicolumn{6}{|c|}{ Fine root recovery rate $\left(\mathrm{yr}^{-1}\right)$} \\
\hline & & $\begin{array}{l}\text { Fagus } \\
\text { sylvatica }\end{array}$ & $\begin{array}{l}\text { Fraxinus } \\
\text { excelsior }\end{array}$ & $\begin{array}{l}\text { Tilia } \\
s p .\end{array}$ & $\begin{array}{l}\text { Acer } \\
\text { sp. }\end{array}$ & $\begin{array}{l}\text { Carpinus } \\
\text { betulus }\end{array}$ & Stand total \\
\hline DL 1 & $0-20$ & $\begin{array}{l}0.26 \\
\pm 0.03 \mathrm{a}\end{array}$ & & & & & $\begin{array}{l}0.26 \\
\pm 0.03 \mathrm{~A}\end{array}$ \\
\hline DL 2 & $0-20$ & $\begin{array}{l}0.47 \\
\pm 0.17 \text { a } \alpha\end{array}$ & $\begin{array}{l}0.37 \\
\pm 0.07 \text { a } \alpha\end{array}$ & $\begin{array}{l}0.16 \\
\pm 0.08 \text { a } \alpha\end{array}$ & $\begin{array}{l}0.18 \\
\pm 0.07 \text { a } \alpha\end{array}$ & & $\begin{array}{l}0.34 \\
\pm 0.07 \mathrm{AB}\end{array}$ \\
\hline DL 3 & $0-20$ & $\begin{array}{l}0.85 \\
\pm 0.54 \text { a } \alpha\end{array}$ & $\begin{array}{l}0.35 \\
\pm 0.06 \text { a } \alpha\end{array}$ & $\begin{array}{l}0.63 \\
\pm 0.10 \mathrm{~b} \mathrm{a}\end{array}$ & $\begin{array}{l}0.48 \\
\pm 0.18 \text { a } \alpha\end{array}$ & $\begin{array}{l}0.64 \\
\pm 0.10 \alpha\end{array}$ & $\begin{array}{l}0.51 \\
\pm 0.07 \mathrm{~B}\end{array}$ \\
\hline
\end{tabular}

The ingrowth of tree and herb fine roots into the root-free soil cores was significantly correlated to a number of forest stand characteristics and edaphic parameters (Table 4.4). The strongest correlation was found between the Shannon index of the tree species and the annual root growth of trees $(r=0.79 ; p<0.001)$ and herbs $(r=0.72 ; p<0.01)$. In contrast, standing fine root biomass was neither related to tree root growth nor herb root growth into the ingrowth cores. However, the annual growth of tree and herb roots showed positive relationships to the base saturation and soil $\mathrm{pH}\left(\mathrm{H}_{2} \mathrm{O}\right)$, while no significant correlation was found to soil water content. Daily mean summer soil temperature in $5 \mathrm{~cm}$ soil depth showed a positive relationship only to the ingrowth of trees, not to that of herbs. 
Table 4.4 Correlation coefficients for linear regressions between fine root growth into ingrowth cores $(0-10 \mathrm{~cm}$ soil depth, $\mathrm{n}=12)$ and Shannon index, evenness, tree fine root biomass*, base saturation*, $\mathrm{pH}\left(\mathrm{H}_{2} \mathrm{O}\right)^{*}$, soil water content* and soil temperature in $5 \mathrm{~cm}$ soil depth of the respective plots $(*$ for $0-10 \mathrm{~cm}$ soil depth). Significant relationships are printed in bold $(\mathrm{p}<0.05)$.

\begin{tabular}{|c|c|c|c|c|c|c|}
\hline \multirow[b]{2}{*}{ Source } & \multicolumn{3}{|c|}{$\begin{array}{c}\text { Tree fine root } \\
\text { growth }\left(\mathrm{g} \mathrm{m}^{-2} \mathrm{yr}^{-1}\right)\end{array}$} & \multicolumn{3}{|c|}{$\begin{array}{l}\text { Herb fine root } \\
\text { growth }\left(\mathrm{g} \mathrm{m}^{-2} \mathrm{yr}^{-1}\right)\end{array}$} \\
\hline & $\mathbf{r}$ & $\mathbf{r}_{\text {adj }}^{2}$ & $\mathbf{p}$ & $\mathbf{r}$ & $\mathbf{r}_{\text {adj }}^{2}$ & $\mathbf{p}$ \\
\hline Shannon index (tree species) & 0.79 & 0.60 & $<0.001$ & 0.72 & 0.47 & $<0.01$ \\
\hline Evenness (tree species) & 0.71 & 0.45 & $<0.01$ & 0.61 & 0.37 & $<0.01$ \\
\hline Fine root biomass * & 0.39 & 0.07 & 0.10 & 0.17 & -0.07 & 0.30 \\
\hline Base saturation * & 0.71 & 0.46 & $<0.01$ & 0.62 & 0.33 & $<0.01$ \\
\hline $\mathrm{pH}\left(\mathrm{H}_{2} \mathrm{O}\right)$ * & 0.75 & 0.52 & $<0.01$ & 0.61 & 0.31 & $<0.05$ \\
\hline Soil water content * (June-August) & -0.26 & -0.03 & 0.21 & -0.30 & -0.01 & 0.18 \\
\hline Soil water content * (annual mean) & 0.29 & -0.01 & 0.19 & 0.17 & 0.07 & 0.30 \\
\hline Soil temperature (June-August) & 0.64 & 0.35 & $<0.01$ & 0.40 & 0.07 & 0.10 \\
\hline Soil temperature (annual mean) & 0.30 & -0.01 & 0.17 & 0.12 & -0.08 & 0.36 \\
\hline
\end{tabular}

\subsection{Discussion}

\section{Root system resilience}

Ingrowth cores were developed as an approach for estimating fine root growth in a simple and repeatable manner (e.g. Persson 1979, 1983; Vogt et al. 1998, Makkonen \& Helmisaari 1999; Jentschke et al. 2001). However, this method introduces a major disturbance to the rhizosphere upon core installation, and thus often yields biased root production estimates (Powell \& Day 1991; Makkonen \& Helmisaari 1999; Hertel \& Leuschner 2002; Ostonen et al. 2005). On the other hand, this disturbance may represent a well defined, replicated experiment to analyse the local recovery of the fine root system and thus may serve as a measure of the root system's resilience after disturbance. Our ingrowth core experiment with 30 cores per plot (in total 360 cores), which were exposed for 24 month, showed a 
significant increase in the rate of fine root ingrowth into the cores from $72 \mathrm{~g} \mathrm{~m}^{-2} \mathrm{yr}^{-1}$ in the monospecific DL 1 plots to $167 \mathrm{~g} \mathrm{~m}^{-2} \mathrm{yr}^{-1}$ in the species-rich DL 3 plots, i.e. a more than twice as rapid ingrowth when 5 species were present with their roots in the soil as compared to soils with only one root species. The recovery rate of fine root biomass in the cores increased significantly from $0.26 \mathrm{yr}^{-1}$ in the DL 1 plots to $0.51 \mathrm{yr}^{-1}$ in the species-rich DL 3 plots. We interpret these results as evidence in support of the insurance hypothesis of biodiversity in the sense that a forest with a higher tree diversity recovers more rapidly in its fine root system after a topsoil disturbance. However, an alternative explanation of different root ingrowth rates, which refers to differences in soil chemistry, has also to be considered. Soil $\mathrm{pH}\left(\mathrm{H}_{2} \mathrm{O}\right)$ was about 1.0 to 1.5 units lower in the monospecific DL 1 stands than in the DL 2 and DL 3 stands, which is thought to be mainly a consequence of the higher acidification potential of beech leaves (Guckland et al. 2008). Thus, it could be that effects of soil acidity on root growth are interfering with diversity effects on fine root growth in our study. However, comparative studies of fine root productivity along soil acidity gradients revealed no decrease in production with increasing acidity in beech forests (Hertel 1999), or even an increase in Norway spruce forests (Jentschke et al. 2001; Godbold et al. 2003). Thus, it appears that the different root growth rates in the ingrowth cores of our study are mainly a consequence of the diversity gradient and not of the acidity gradient.

A higher root system resilience should be relevant for various types of topsoil disturbance that occur irregularly in forests, e.g. by uprooting of trees, through the foraging activity of wild boar or by logging activities. We assume that species-rich forests are able to recolonise disturbed, root-free soil patches more rapidly than species-poor stands. Different phenologies of fine root growth of the five species could be one reason for a faster recovery of more diverse tree root systems. In the case of the herb root response, we assume that the only sparse cover of the herb layer in the DL 1 plots has retarded the root ingrowth as compared to the DL 2 and DL 3 plots with a richer herb layer.

\section{Seasonality of fine root biomass and necromass}

Temperate tree species have been found to differ markedly in their phenologies of fine root growth, resulting from different endogenous rhythms of carbon allocation to roots and contrasting root growth responses to temperature (Teskey \& Hinckley 1981; Lyr \& Garbe 1995; Lyr 1996). For example, maximum root growth of Fagus and Tilia was observed at 
$20^{\circ} \mathrm{C}$, while Carpinus revealed optimal root growth at higher temperatures $\left(25-30^{\circ} \mathrm{C}\right)$ and Acer pseudoplatanus at lower temperatures (15-20 $\mathrm{C})$ (Lyr \& Garbe 1995; Lyr 1996). Moreover, cold temperature seems to inhibit root growth of temperate tree species differently (Tryon \& Chapin 1983; Steele et al. 1997). Thus, we can expect that different fine root growth rhythms overlay each other in mixed stands which should result in a less distinct seasonality of fine root biomass in species-rich stands as compared to species-poor ones. In our study, the majority of tree species showed an increase in standing fine root biomass from April to end of June 2006, and a more or less constant biomass (or a slight decrease) through the autumn and winter 2006/2007. Even though we observed opposing seasonal biomass trends in certain coexisting species (e.g. in Fraxinus and Tilia in stand DL 3a), seasonality of fine root biomass was generally low on the species level and also on the stands level. Moreover, we found no indication of a more pronounced biomass seasonality in the monospecific beech stands (DL 1a) as compared to the mixed DL $2 \mathrm{c}$ and DL 3a stands. In general, there was a root biomass increase from April to the end of June (which was significant in the DL 1a and DL 3a plots) and a more or less constant biomass during summer, autumn and also winter. This is astonishing since soil temperature at $5 \mathrm{~cm}$ depth varied between 19.6 and $0.4{ }^{\circ} \mathrm{C}$ over the year and soil moisture reached minima during dry periods in the end of July 2006. Thus, neither drought nor winter temperature resulted in a significant decrease of standing fine root biomass in the Hainich forest. Low seasonal variations in fine root biomass have also been reported from other temperate and boreal forests, e.g. in Scots pine stands in Scandinavia (Persson 1978, 1983; Makkonen \& Helmisaari 1998). On the other hand, Vogt et al. (1981) and McClaugherty et al. (1982) observed one or more distinct fine root biomass peaks in temperate North American forests.

In our study, seasonality was generally more pronounced in fine root necromass than in fine root biomass in all plots. Necromass increased during summer and decreased strongly during winter in the mixed DL 2 and DL 3 plots, while it reached a peak in April and September and decreased only slightly during the winter in the beech-dominated DL 1 plot. Contrasting to our results from the mixed plots, Konôpka et al. (2006) and McClaugherty et al. (1982) found that the amount of necromass was larger at the beginning and the end of the growing season than in mid-summer. Like in our study, Hertel (1999) found a fine root necromass accumulation during summer in four beech forests. Necromass peaks in summer or autumn may result from elevated root mortalities, or reduced root decomposition rates, both induced by summer droughts. 
In the absence of fine root decomposition data, we can only speculate about the fate of root necromass which disappeared during the observation period. In our study, fine root necromass decreased by 51-71\% in the mixed DL 2 and DL 3 plots from the September to the April sampling date which points to a rapid fine root decomposition even during autumn and winter. Similar to leaf litter (Brauns, unpublished), fine roots were found to decompose faster in the mixed plots. A very fast fine root decomposition was also observed in a minirhizotron study, in which the majority of birch and maple fine roots, that died during the winter, disappeared completely in April and showed a median decomposition rate of 35 days (Tierney et al. 2001). Joslin \& Henderson (1987) determined an annual fine root decomposition rate of 30-35 \% in a mixed hardwood forest, while Norway spruce (Gaul et al. 2008), Sugar maple and White pine (McClaugherty et al. 1982 , 1984) fine roots decomposed with mass losses of 12-26 \% per year. Fine root decay processes are investigated almost exclusively with litterbags (Silver \& Miya 2001). Estimations from an 'intact-core' technique however, revealed $10-23 \%$ greater annual mass losses, indicating an under-estimation of fine root decomposition by the litterbag method (Dornbush et al. 2001).

The more rapid fine root decomposition in the DL $2 \mathrm{c}$ and DL 3a plots in autumn and winter, as inferred from the pronounced necromass decrease, may be explained by the higher $\mathrm{pH}$-values and higher base saturation of the soil in these plots, favouring decomposing rates.

\section{Estimates of fine root production}

In the absence of minirhizotron data, conclusions on fine root biomass production must remain vague when they are based on the results of only on a few sequential root coring dates. This is especially true in stands with a low root biomass seasonality as in our study. On the other hand, a rough estimate may be justified when not absolute production numbers are sought, but rather a comparison of stands investigated with the same method is the goal. This approach gave roughly three times larger annual fine root production estimates for the two mixed stands (DL 2c and DL 3a) than for the beech-dominated DL 1a stand (about 500-550 vs. $180 \mathrm{~g} \mathrm{~m}^{-2} \mathrm{yr}^{-1}$ ). While we are sceptical about the absolute height of the numbers, the trend for higher production rates in the species-rich stands is supported by the results of the ingrowth core study which independently produced evidence of a roughly twofold increase in fine root growth rates between the DL 1 and DL 3 plots. We 
are aware of only two studies which compared fine root productivity in pure and mixed cultures of woody plants.

In agreement with our results, Fredericksen \& Zedaker (1995) observed a greater fine root production in mixtures of loblolly pine and black locust saplings than in pure stands of these two species. On the other hand, McKay \& Malcolm (1988) report an about twofold higher fine root production in pure stands of spruce and pine compared to mixtures of these species.

Thus, further investigations with more reliable methods for quantifying fine root production are needed in order to answer the question as to whether below-ground productivity of forests is enhanced by tree species diversity. Our results both from the ingrowth core and the sequential coring study point in this direction.

\section{Acknowledgements}

This study was conducted in the context of Graduiertenkolleg 1086 'The role of biodiversity for biogeochemical cycles and biotic interactions in temperate deciduous forests'. We thank the National Park administration for the permission to accomplish the study in the Hainich National Park and for funding by the German Research Council (DFG). We thank all participants of the Graduiertenkolleg for excellent teamwork. Data of forest stand characteristics were kindly provided by Mascha Brauns, Anja Guckland, Inga Krämer, Andreas Mölder and Inga Schmidt. 


\subsection{References}

Andren O, Rajkai K, Katterer T (1991) A nondestructive technique for studies of root distribution in relation to soil-moisture. Agriculture Ecosystems \& Environment $34: 269-278$

Bartelink HH, Olsthoorn AFM (1999) Mixed forest in western Europe. In: Olsthoorn AFM, Bartelink HH, Gardiner JJ, Pretzsch H, Hekhuis HJ, Franc A (eds) Management of mixed-species forest: silviculture and economics. IBN Scientific Contributions, Wageningen, pp 9-16

Chapin FS, Zavaleta ES, Eviner VT, Naylor RL, Vitousek PM, Reynolds HL, Hooper DU, Lavorel S, Sala OE, Hobbie SE, Mack MC, Diaz S (2000) Consequences of changing biodiversity. Nature 405:234-242

DeAngelis DL, Gardner RH, Shugart HH (1981) Productivity of forest ecosystems studies during IBP: the woodland data set. In: Reichle DE (ed) Dynamic properties of forest ecosystems. Cambridge University Press, Cambridge, pp 567-659

Dornbush ME, Isenhart TM, Raich JW (2001) Quantifying fine-root decomposition: an alternative to buried litterbags. Ecology 83:2985-2990

Fitter A (1996) Characteristics and functions of root systems. In: Weisel Y, Eshel A, Kafkafi U (eds) Plant roots: the hidden half. Dekker, New York, pp 1-20

Fredericksen TS, Zedaker SM (1995) Fine root biomass, distribution, and production in young pine-hardwood stands. New Forests 10:99-110

Godbold DL, Fritz HW, Jentschke G, Meesenburg H, Rademacher P (2003) Root turnover and root necromass accumulation of Norway spruce (Picea abies) are affected by soil acidity. Tree Physiology 23:915-921

Gaul D, Hertel D, Borken W, Matzner E, Leuschner C (2008) Effects of experimental drought on the fine root system of mature Norway spruce. Forest Ecology and Management, in press

Guckland A, Brauns M, Flessa H, Thomas FM, Leuschner C (2008) Acidity, nutrient stocks and organic matter content in soils of a temperate deciduous forest with different abundance of European beech (Fagus sylvatica L.). Journal of Plant Nutrition and Soil Science, in press

Hector A, Schmid B, Beierkuhnlein C, Caldeira MC, Diemer M, Dimitrakopoulos PG, Finn JA, Freitas H, Giller PS, Good J, Harris R, Högberg P, Huss-Danell K, Joshi J, Jumpponen A, Körner C, Leadley PW, Loreau M, Minns A, Mulder CPH, O'Donovan G, Otway SJ, Pereira JS, Prinz A, Read DJ, Scherer-Lorenzen M, Schulze ED, Siamantziouras ASD, Spehn EM, Terry AC, Troumbis AY, Woodward FI, Yachi S, Lawton JH (1999) Plant diversity and productivity experiments in European grasslands. Science 286:1123-1127 
Hertel D (1999) Das Feinwurzelsystem von Rein- und Mischbeständen der Rotbuche: Struktur, Dynamik und interspezifische Konkurrenz. Dissertationes Botanicae 317. Gebrüder Borntraeger, Berlin, Stuttgart

Hertel D, Leuschner C (2002) A comparison of four different fine root production estimates with ecosystem carbon balance data in a Fagus-Quercus mixed forest. Plant and Soil 239:237-251

Hölscher D, Hertel D, Leuschner C, Hottkowitz M (2002) Tree species diversity and soil patchiness in a temperate broad-leaved forest with limited rooting space. Flora 197:118-125

Jentschke G, Drexhage M, Fritz HW, Fritz E, Schella B, Lee DH, Gruber F, Heimann J, Kuhr M, Schmidt J, Schmidt S, Zimmermann R, Godbold DL (2001) Does soil acidity reduce subsoil rooting in Norway spruce (Picea abies)? Plant and Soil 237:91-108

Johnson MG, Tingey DT, Phillips DL, Storm MJ (2001) Advancing fine root research with minirhizotrons. Environmental and Experimental Botany 45:263-289

Joslin JD, Henderson GS (1987) Organic matter and nutrients associated with fine root turnover in a White oak stand. Forest Science 33:330-346

Kelty MJ (1992) Comparative productivity of monocultures and mixed stands. In: Kelty MJ, Larson BC, Oliver CD (eds) The ecology and silviculture of mixed-species forests. Kluwer, Dordrecht pp 125-141

Konôpka B, Noguchi K, Sakata T, Takahashi M, Konôpkova Z (2006) Fine root dynamics in a Japanese cedar (Cryptomeria japonica) plantation throughout the growing season. Forest Ecology and Management 225:278-286

Korn S (2004) Experimentelle Untersuchung der Wasseraufnahme und der hydraulischen Eigenschaften des Wurzelsystems von sechs heimischen Baumarten. PhD thesis, University of Göttingen. http://webdoc.sub.gwdg.de/diss/2004/korn

Leuschner C, Backes K, Hertel D, Schipka F, Schmitt U, Terborg O, Runge M (2001) Drought responses at leaf, stem and fine root levels of competitive Fagus sylvatica L. and Quercus petraea Matt. Liebl. trees in dry and wet years. Forest Ecology and Management 149:33-46

Leuschner C, Jungkunst HF, Fleck S (2008) Studying the functional role of tree diversity in forests: the pros and cons of synthetic stands and across-site comparisons in established forests. Basic and Applied Ecology, in press

Loreau M, Hector A (2001) Partitioning selection and complementarity in biodiversity experiments. Nature 412:72-76

Lyr H, Garbe V (1995) Influence of root temperature on growth of Pinus sylvestris, Fagus sylvatica, Tilia cordata and Quercus robur. Trees-Structure and Function 9:220223

Lyr H (1996) Effect of the root temperature on growth parameters of various European tree species. Annales des Sciences Forestieres 53:317-323 
Majdi H (1996) Root sampling methods - Applications and limitations of the minirhizotron technique. Plant and Soil 185:255-258

Makkonen K, Helmisaari HS (1998) Seasonal and yearly variations of fine-root biomass and necromass in a Scots pine (Pinus sylvestris L.) stand. Forest Ecology and Management 102:283-290

Makkonen K, Helmisaari HS (1999) Assessing fine-root biomass and production in a Scots pine stand - comparison of soil core and root ingrowth core methods. Plant and Soil 210:43-50

McClaugherty CA, Aber JD, Melillo JM (1982) The role of fine roots in the organic matter and nitrogen budgets of two forested ecosystems. Ecology 635:1481-1490

McClaugherty CA, Aber JD, Melillo JM (1984) Decomposition dynamics of fine roots in forested ecosystems. Oikos 42:378-386

McKay HM, Malcolm DC (1988) A comparison of the fine root component of a pure and a mixed coniferous stand. Canadian Journal of Forest Research 18:1416-1426

Mölder A, Bernhardt-Römermann M, Schmidt W (2006) Forest ecosystem research in Hainich National Park Thuringia: First results on flora and vegetation in stands with contrasting tree species diversity. Waldoekologie online 3:83-99

Nadelhoffer KJ, Raich JW (1992) Fine root production estimates and belowground carbon allocation in forest ecosystems. Ecology 73:1139-1147

Ostonen I, Lohmus K, Pajuste K (2005) Fine root biomass, production and its proportion of NPP in a fertile middle-aged Norway spruce forest: Comparison of soil core and ingrowth core methods. Forest Ecology and Management 212:264-277

Persson H (1978) Root dynamics in a young Scots pine stand in Central Sweden. Oikos 30:508-519

Persson H (1979) Fine-root production, mortality and decomposition in forest ecosystems. Vegetatio 41:101-109

Persson H (1983) The distribution and production of fine roots in boreal forests. Plant and Soil 71:87-101

Peterson G, Allen CR, Holling CS (1998) Ecological resilience, biodiversity, and scale. Ecosystems 1:6-18

Powell SW, Day FP (1991) Root production in four communities in the Great Dismal Swamp. American Journal of Botany 78:288-297

Pretzsch H (2005) Diversity and Productivity in forests: evidence from long-term experimental plots. In: Scherer-Lorenzen M, Körner C, Schulze ED (eds) Forest Diversity and Function: Temperate and Boreal Systems, Ecological Studies. Springer, Berlin pp 41-64 
Ruess RW, van Cleve K, Yarie J, Viereck LA (1996) Contributions of fine root production and turenover to the carbon and nitrogen cycling in taiga forsts of the Alaskan interior. Canadian Journal of Forest Research 26:1326-1336

Scherer-Lorenzen M, Schulze ED, Don A, Schumacher J, Weller E (2007) Exploring the functional significance of forest diversity: A new long-term experiment with temperate tree species BIOTREE. Perspectives in Plant Ecology Evolution and Systematics 9:53-70

Silver WL, Miya RK (2001) Global patterns in root decomposition: comparisons of climate and litter quality effects. Oecologia 129:407-419

Steele SJ, Gower ST, Vogel JG, Norman JM (1997) Root mass, net primary production and turnover in aspen, jack pine and black spruce forests in Saskatchewan and Manitoba, Canada. Tree Physiology 17:577-587

Teskey RO, Hinckley TM (1981) Influence of temperature and water potential on root growth of white oak. Physiologia Plantarum 52:363-369

Tierney GL, Fahey TJ, Groffman PM, Hardy JP, Fitzhugh RD, Driscoll CT (2001) Soil freezing alters fine root dynamics in a northern hardwood forest. Biogeochemistry $56: 175-190$

Tilman D, Wedin D, Knops J (1996) Productivity and sustainability influenced by biodiversity in grassland ecosystems. Nature 379:718-720

Tilman D, Lehman CL, Thomson KT (1997) Plant diversity and ecosystem productivity: Theoretical considerations. Proceedings of the National Academy of Sciences of the United States of America 94:1857-1861

Tilman D (1999) Ecology - Diversity and production in European grasslands. Science 286:1099-1100

Tilman D, Reich PB, Knops J, Wedin D, Mielke T, Lehman C (2001) Diversity and productivity in a long-term grassland experiment. Science 294:843-845

Trumbore SE, Gaudinski JB (2003) The secret lives of roots. Science 302:1344-1345

Tryon PR, Chapin FS (1983) Temperature control over root-growth and root biomass in Taiga forest trees. Canadian Journal of Forest Research 13:827-833

van Praag HJ, Sougnezremy S, Weissen F, Carletti G (1988) Root turnover in a beech and a spruce stand of the Belgian Ardennes. Plant and Soil 105:87-103

Vogt KA, Edmonds RL, Grier CC (1981) Seasonal changes in biomass and vertical distribution of mycorrhizal and fibrous-textured conifer fine roots in 23- and 180year-old subalpine Abies amabilis stands. Canadian Journal of Forest Research $11: 223-229$

Vogt KA, Vogt DJ, Palmiotto PA, Boon P, Ohara J, Asbjornsen H (1996) Review of root dynamics in forest ecosystems grouped by climate, climatic forest type and species. Plant and Soil 187:159-219 
Vogt KA, Vogt DJ, Bloomfield J (1998) Analysis of some direct and indirect methods for estimating root biomass and production of forests at an ecosystem level. Plant and Soil 200:71-89

Xiao CW, Yuste JC, Janssens IA, Roskams P, Nachtergale L, Carrara A, Sanchez BY, Ceulemans R (2003) Above- and belowground biomass and net primary production in a 73-year-old Scots pine forest. Tree Physiology 23:505-516 
CHAPTER

Synthesis 


\subsection{Has tree species diversity an effect on below-ground processes?}

\section{Fine root bio- and necromass}

Fine root biomass of the forest stands was not affected by tree species diversity. Fine root necromass also did not differ significantly between the plots differing in tree species diversity, but the tree species-rich plots tended to hold less fine root necromass than the plots dominated by 1 or 3 tree species. This finding is surprising since marked effects of increasing plant diversity on ecosystem functions are expected particularly in plant communities with relatively small numbers of species (Tilman et al. 1996; Jolliffe 1997; Hector et al. 1999). A comparison of our results with available literature data shows that the fine root biomass records of 440-480 $\mathrm{g} \mathrm{m}^{-2}$ in this study are well in accordance with the mean value of $482 \mathrm{~g} \mathrm{~m}^{-2}$ given for temperate deciduous broad-leaved forests in the metaanalysis Leuschner \& Hertel (2003). Compared to the results of other studies (Chapter 2, Table 2.6), fine root biomass and, hence, fine root densities in the mixed DL 2 and DL 3 plots were relatively high, thus indicating high interspecific below-ground competition in these stands. In addition, the majority of fine root biomass was found in the upper $20 \mathrm{~cm}$ of the soil and most soil samples contained fine roots of two or more tree species, which also indicates high interspecific below-ground competition intensities in the Hainich forest stands (Chapter 2). Nevertheless, we found no evidence for a shift of fine roots to deeper soil layers as a consequence of interspecific competition (Chapter 3). The clayey soil with a high resistance to root penetration may be one reason for the similar vertical root distribution patterns of the different tree species in the Hainich stands, making spatial root segregation difficult in these soils. This might explain why increasing tree species diversity did not lead to an increasing fine root biomass in the Hainich stands. Our results led to the rejection of hypothesis (i) that stand fine root biomass increases with increasing tree species diversity and did not confirm the hypothesis (ii) that 'overyielding' in terms of fine root biomass is a consequence of spatial fine root separation in the species-rich stands. Furthermore, standing fine root biomass did not correlate with fine root production (see Chapter 4) which should be a more decisive parameter to be quantified for an assessment of the below-ground 'overyielding' phenomenon. 


\section{Fine root morphology}

Our study revealed some marked differences in fine root morphological traits between the co-occurring species. Interestingly, there were no systematic differences in fine root morphology between tree species infected by ectomycorrhiza-forming (ECM) fungi like Fagus, Tilia, Carpinus, Ulmus, Quercus, Prunus and tree species with arbuscular mycorrhiza (VA) such as Fraxinus and Acer. On the contrary, the VA-infected genera Fraxinus and Acer showed the two most dissimilar fine root architectures, with Acer (A. platanoides and A. pseudoplatanus) exhibiting fine roots of particular small diameter, large specific root area (SRA) values and a high specific root tip abundance, while Fraxinus possesses fine roots with large diameters, small SRAs and a low specific root tip abundance. The ECM-infected species were less variable in their fine root morphological traits, ranging with their values between the two VA-infected species. In general, data on fine root morphology of Central Europe broad-leaved tree species are rare: Withington et al. (2006) found similar fine root diameter distributions for Fagus and Tilia species, but higher fine root diameters in Acer species as compared to our study. The SRA records for Tilia, Fagus, Fraxinus, Acer, and Ulmus in the study of Hölscher et al. (2002) were somewhat lower than our results, but confirmed the large difference between the two VAinfected genera Acer and Fraxinus. Data on specific root tip abundance in fine roots of different deciduous tree species in Europe are virtually missing in the literature.

Given the apparent species-specific differences in root morphology between co-occurring tree species, effects of increasing tree species diversity on fine root architecture in general could not be detected in our study. Exceptions were only found in Fagus fine roots that showed smaller fine root diameters and higher specific root tip abundances and SRA values in DL 2 plots than in the monospecific beech plots (DL 1); similarly, Tilia fine roots showed higher SRA values in the species-rich DL 3 plots than in the DL 2 plots, while root diameter and root tip frequency remained unchanged. The overall lack of changes in fine root morphology in response to the presence of allospecific competitors is surprising, since several authors have emphasized the meaning of architectural plasticity versus allocational plasticity as an important adaptation mode to variable growth conditions (e.g. Bauhus \& Messier 1999, Curt \& Prévosto 2003).

Although fine root morphology differed among the tree species, it had no significant influence on stand totals of fine root biomass. Root tip abundance (number of root tips per $\mathrm{m}^{2}$ ground area) tended to be lower in the species-rich DL 3 plots due to the low specific root tip abundance of Fraxinus, but this finding was not statistically significant. The root 
surface area indices of the stands, on the other hand, were almost identical between the diversity levels but high in comparison to literature data (see Jackson et al. 1997; Leuschner et al. 2004), thus confirming that the upper soil horizons in our study plots were densely exploited by fine roots independently of the composition of the tree layer.

\section{Fine root production}

In the absence of minirhizotron data, conclusions on fine root biomass production must remain vague when they are based on the results of only on a few sequential root coring dates. This is especially true in stands with a low root biomass seasonality as in our study (Chapter 4). On the other hand, a rough estimate may be justified when not absolute production numbers are sought, but rather a comparison of stands investigated with the same method is the goal. The sequential coring approach gave roughly three times larger annual fine root production estimates for the two mixed stands (DL 2c and DL 3a) than for the beech-dominated DL 1a stand (about 500-550 vs. $180 \mathrm{~g} \mathrm{~m}^{-2} \mathrm{yr}^{-1}$ ). While we are sceptical about the absolute height of the numbers, the trend for higher production rates in the species-rich stands is supported by the results of the ingrowth core study which independently produced evidence of a roughly twofold increase in fine root growth rates between the DL 1 and DL 3 plots. We are aware of only two studies which compared fine root productivity in pure and mixed cultures of woody plants. In agreement with our results, Fredericksen \& Zedaker (1995) observed a greater fine root production in mixtures of loblolly pine and black locust saplings than in pure stands of these two species. On the other hand, McKay \& Malcolm (1988) report an about twofold higher fine root production in pure stands of spruce and pine compared to mixtures of these species.

Thus, further investigations with more reliable methods for quantifying fine root production are needed in order to answer the question as to whether below-ground productivity of forests is enhanced by tree species diversity. Our results both from the ingrowth core and the sequential coring study point in this direction. 


\subsection{Are there indicators for spatial niche-partitioning in the rhizosphere?}

\section{Vertical fine root distribution}

The majority of fine root bio- and necromass was found in the upper $20 \mathrm{~cm}$ of the soil (64$79 \%$ ). All tree species showed a strong exponential decrease of fine root biomass with soil depth, irrespective of the species diversity in the stands. This was confirmed by applying a regression equation of the form $y=1-\beta^{d}$ (Gale \& Grigal (1987) with $y=$ cumulative fine root biomass fraction in $\mathrm{g} \mathrm{m}^{-2}$ and $\mathrm{d}=$ soil depth) to the fine root biomass data of the tree species present in the different stands. The similarity of the $\beta$ values $(0.92-0.94$ for Fagus in DL 1-DL 3 plots, 0.92 for Fraxinus in DL 2-3 plots, 0.92-0.93 for Tilia in DL 2-3 plots, and 0.91-0.92 for Acer in DL 2-3 plots) indicates a rather superficial rooting pattern of all species (Chapter 3). According to these results, a pronounced segregation of the fine root systems of the co-occurring tree species did not exist in the stands. Avoidance of competition could be one cause of a vertical stratification of root systems in species-rich stands. Hence, it is surprising that a corresponding vertical stratification of the fine root mass of the different species did not occur in the mixed stands of the Hainich forest. Assuming that below-ground competition is the cause of root system segregation, one may expect that competition intensity is less in soils with high nutrient availability as in the Hainich forest, thus reducing the benefit of avoiding competition through spatial niche differentiation in terms of different rooting depth.

\section{Horizontal fine root distribution}

The fine root systems had a far larger horizontal extension than the corresponding tree crowns in the mixed stands. With an estimated maximum diameter of the fine root system of $20 \mathrm{~m}$ in Fagus and Carpinus, trees of these species may spread their fine roots over an area of more than $300 \mathrm{~m}^{2}$, which is roughly five times the size of the corresponding crown projection area (Kochenderfer 1973; Mou \& Jones 1995; Müller \& Wagner 2003; Johnsen et al. 2005). Rewald \& Leuschner (submitted) reported about a maximum root extension of even $30 \mathrm{~m}$ in the case of Tilia trees. For Fraxinus, Tilia and Acer, we found a gradual decrease in fine root density with increasing stem distance within a radius of $10 \mathrm{~m}$ or more, but not a strict stem-centered distribution pattern as it was observed, for example, in spruce forests by Bédéneau \& Auclair (1989) and Nielsen \& Mackenthun (1991). Only in the case 
of Carpinus and Fagus trees growing in the mixed stands, fine root biomass showed a steep decrease within an $8 \mathrm{~m}$-radius around the stems. Depending on tree species, the decrease was best described either by a linear or a sigmoid equation. The Acer species showed a remarkable rooting pattern by maintaining only rather low root densities in the mixed stands which, however, extended over a large area and reached maximum stem distances of up to $20 \mathrm{~m}$.

Our data showed a high degree of a root system overlap in all mixed stands, and even did so in the pure beech stands where the rare species intermingled largely with the dominant beech roots (Chapter 3). This is in agreement with data obtained in two species beech-oak stands where both tree species were present in more than $95 \%$ of all root samples (Büttner \& Leuschner 1994; Leuschner et al. 2001). Similarly to Rewald \& Leuschner (submitted), we found no indications of a 'territoriality' of tree fine root systems in these stands as it was suggested by Schenk et al. (1999).

\subsection{Does tree species diversity enhance fine root resilience?}

Ingrowth cores were developed as an approach for estimating fine root growth in a simple and repeatable manner (e.g. Persson 1979, 1983; Vogt et al. 1998, Makkonen \& Helmisaari 1999; Jentschke et al. 2001). However, this method introduces a major disturbance to the rhizosphere upon core installation, and thus often yields biased root production estimates (Powell \& Day 1991; Makkonen \& Helmisaari 1999; Hertel \& Leuschner 2002; Ostonen et al. 2005). On the other hand, this disturbance may represent a well defined, replicated experiment to analyse the local recovery of the fine root system and thus may serve as a measure of the root system's resilience after disturbance. Our ingrowth core experiment with 30 cores per plot (in total 360 cores), which were exposed for 24 month, showed a significant increase in the rate of fine root ingrowth into the cores from $72 \mathrm{~g} \mathrm{~m}^{-2} \mathrm{yr}^{-1}$ in the monospecific DL 1 plots to $167 \mathrm{~g} \mathrm{~m}^{-2} \mathrm{yr}^{-1}$ in the species-rich DL 3 plots, i.e. a more than twice as rapid ingrowth when 5 species were present with their roots in the soil as compared to soils with only one root species. The recovery rate of fine root biomass in the cores increased significantly from $0.26 \mathrm{yr}^{-1}$ in the DL 1 plots to $0.51 \mathrm{yr}^{-1}$ in the species-rich DL 3 plots. We interpret these results as evidence in support of the insurance hypothesis of biodiversity in the sense that a forest with a higher tree diversity recovers more rapidly in its fine root system after a topsoil disturbance. However, an alternative explanation of 
different root ingrowth rates, which refers to differences in soil chemistry, has also to be considered. Soil $\mathrm{pH}\left(\mathrm{H}_{2} \mathrm{O}\right)$ was about 1.0 to 1.5 units lower in the monospecific DL 1 stands than in the DL 2 and DL 3 stands, which is thought to be mainly a consequence of the higher acidification potential of beech leaves (Guckland et al. 2008). Thus, it could be that effects of soil acidity on root growth are interfering with diversity effects on fine root growth in our study. However, comparative studies of fine root productivity along soil acidity gradients revealed no decrease in production with increasing acidity in beech forests (Hertel 1999), or even an increase in Norway spruce forests (Jentschke et al. 2001; Godbold et al. 2003). Thus, it appears that the different root growth rates in the ingrowth cores of our study are mainly a consequence of the diversity gradient and not of the acidity gradient.

A higher root system resilience should be relevant for various types of topsoil disturbance that occur irregularly in forests, e.g. by uprooting of trees, through the foraging activity of wild boar or by logging activities. We assume that species-rich forests are able to recolonise disturbed, root-free soil patches more rapidly than species-poor stands. Different phenologies of fine root growth of the five species could be one reason for a faster recovery of more diverse tree root systems. 


\subsection{References}

Bauhus J, Messier C (1999) Soil exploitation strategies of fine roots in different tree species of the southern boreal forest of eastern Canada. Canadian Journal of Forest Research 29:260-273

Bédéneau M, Auclair D (1989) The study of tree fine root distribution and dynamics using a combined trench and observation window method. Annales des Sciences Forestieres 46:283-290

Büttner V, Leuschner C (1994) Spatial and temporal patterns of fine root abundance in a mixed oak-beech forest. Forest Ecology and Management 70:11-21

Curt T, Prévosto B (2003) Rooting strategy of naturally regenerated beech in Silver birch and Scots pine woodlands. Plant and Soil 255:265-279

Fredericksen TS, Zedaker SM (1995) Fine root biomass, distribution, and production in young pine-hardwood stands. New Forests 10:99-110

Gale MR, Grigal DF (1987) Vertical root distributions of northern tree species in relation to successional status. Canadian Journal of Forest Research 17:829-834

Godbold DL, Fritz HW, Jentschke G, Meesenburg H, Rademacher P (2003) Root turnover and root necromass accumulation of Norway spruce (Picea abies) are affected by soil acidity. Tree Physiology 23:915-921

Guckland A, Brauns M, Flessa H, Thomas FM, Leuschner C (2008) Acidity, nutrient stocks and organic matter content in soils of a temperate deciduous forest with different abundance of European beech (Fagus sylvatica L.). Journal of Plant Nutrition and Soil Science. In press

Hector A, Schmid B, Beierkuhnlein C, Caldeira MC, Diemer M, Dimitrakopoulos PG, Finn JA, Freitas H, Giller PS, Good J, Harris R, Högberg P, Huss-Danell K, Joshi J, Jumpponen A, Körner C, Leadley PW, Loreau M, Minns A, Mulder CPH, O'Donovan G, Otway SJ, Pereira JS, Prinz A, Read DJ, Scherer-Lorenzen M, Schulze ED, Siamantziouras ASD, Spehn EM, Terry AC, Troumbis AY, Woodward FI, Yachi S, Lawton JH (1999) Plant diversity and productivity experiments in European grasslands. Science 286:1123-1127

Hertel D (1999) Das Feinwurzelsystem von Rein- und Mischbeständen der Rotbuche: Struktur, Dynamik und interspezifische Konkurrenz. Dissertationes Botanicae 317. Gebrüder Borntraeger, Berlin, Stuttgart

Hertel D, Leuschner C (2002) A comparison of four different fine root production estimates with ecosystem carbon balance data in a Fagus-Quercus mixed forest. Plant and Soil 239:237-251

Hölscher D, Hertel D, Leuschner C, Hottkowitz M (2002) Tree species diversity and soil patchiness in a temperate broad-leaved forest with limited rooting space. Flora 197:118-125 
Jackson RB, Mooney HA, Schulze ED (1997) A global budget for fine root biomass, surface area, and nutrient contents. Proceedings of the National Academy of Sciences of the United States of America 94:7362-7366

Jentschke G, Drexhage M, Fritz HW, Fritz E, Schella B, Lee DH, Gruber F, Heimann J, Kuhr M, Schmidt J, Schmidt S, Zimmermann R, Godbold DL (2001) Does soil acidity reduce subsoil rooting in Norway spruce (Picea abies)? Plant and Soil 237:91-108

Johnsen K, Maier C, Kress L (2005) Quantifying root lateral distribution and turnover using pine trees with a distinct stable carbon isotope signature. Functional Ecology 19:81-87

Jolliffe PA (1997) Are mixed populations of plant species more productive than pure stands? Oikos 80:595-602

Kochenderfer JN (1973) Root distribution under some forest types native to West-Virginia. Ecology 54:445-448

Leuschner C, Hertel D, Coners H, Büttner V (2001) Root competition between beech and oak: a hypothesis. Oecologia 126:276-284

Leuschner C, Hertel D (2003) Fine root biomass of temperate forests in relation to soil acidity and fertility, climate, age and species. Progress in Botany 64:405-438

Leuschner C, Hertel D, Schmid I, Koch O, Muhs A, Hölscher D (2004) Stand fine root biomass and fine root morphology in old-growth beech forests as a function of precipitation and soil fertility. Plant and Soil 258:43-56

Makkonen K, Helmisaari HS (1999) Assessing fine-root biomass and production in a Scots pine stand - comparison of soil core and root ingrowth core methods. Plant and Soil $210: 43-50$

McKay HM, Malcolm DC (1988) A comparison of the fine root component of a pure and a mixed coniferous stand. Canadian Journal of Forest Research 18:1416-1426

Mou P, Jones RH (1995) Spatial distribution of roots in Sweetgum and Loblolly Pine monocultures and relations with above-ground biomass and soil nutrients. Functional Ecology, 9:689-699

Müller KH, Wagner S (2003) Fine root dynamics in gaps of Norway spruce stands in the German Ore Mountains. Forestry 76:149-158

Nielsen CCN, Mackenthun G (1991) Spatial variation of fine root biomass intensity in forest soils related to stand density - A numerical-method estimating the rootintensity-bell around single trees. Allgemeine Forst und Jagdzeitung 162:112-119

Ostonen I, Lohmus K, Pajuste K (2005) Fine root biomass, production and its proportion of NPP in a fertile middle-aged Norway spruce forest: Comparison of soil core and ingrowth core methods. Forest Ecology and Management 212:264-277

Persson H (1979) Fine-root production, mortality and decomposition in forest ecosystems. Vegetatio 41:101-109 
Persson HA (1983) The distribution and productivity of fine roots in boreal forests. Plant and Soil 71:87-101

Powell SW, Day FP (1991) Root production in 4 communities in the great dismal swamp. American Journal of Botany 78:288-297

Schenk HJ, Callaway RM, Mahall BE (1999) Spatial root segregation: Are plants territorial? Advances in Ecological Research 28:145-180

Tilman D, Wedin D, Knops J (1996) Productivity and sustainability influenced by biodiversity in grassland ecosystems. Nature 379:718-720

Vogt KA, Vogt DJ, Bloomfield J (1998) Analysis of some direct and indirect methods for estimating root biomass and production of forests at an ecosystem level. Plant and Soil 200:71-89

Withington JM, Reich PB, Oleksyn J, Eissenstat DM (2006) Comparisons of structure and life span in roots and leaves among temperate trees. Ecological Monographs 76:381-397 
ChAPTER

6

Appendix 
Appendix 1 Morphological characteristics for fine root $(<2 \mathrm{~mm}$ in diameter $)$ identification. Own classification and modified from Hertel (1999), Hölscher et al. (2002) and Korn (2004).

\begin{tabular}{|c|c|c|c|}
\hline Species & Colour & Identifying characteristics & $\begin{array}{l}\text { Mycorrhizal } \\
\text { infection }\end{array}$ \\
\hline $\begin{array}{l}\text { Acer } \\
\text { campestre }\end{array}$ & Dark brown & $\begin{array}{l}\text { Fine textured cellular surface; shiny } \\
\text { coating; second order branches irregularly } \\
\text { ramified and of small diameter; very } \\
\text { hairy; clustered and cone shaped root tips }\end{array}$ & $\begin{array}{l}\text { Arbuscular } \\
\text { mycorrhizae }\end{array}$ \\
\hline $\begin{array}{l}\text { Acer } \\
\text { platanoides }\end{array}$ & $\begin{array}{l}\text { Dark beige to } \\
\text { brown }\end{array}$ & $\begin{array}{l}\text { Distinctive rhomboid structured surface; } \\
\text { shiny coating; second order branches } \\
\text { irregularly ramified and of small } \\
\text { diameter; hairy; clustered and cone } \\
\text { shaped root tips }\end{array}$ & $\begin{array}{l}\text { Arbuscular } \\
\text { mycorrhizae }\end{array}$ \\
\hline $\begin{array}{l}\text { Acer } \\
\text { pseudoplatanus }\end{array}$ & $\begin{array}{l}\text { Light to dark } \\
\text { brown }\end{array}$ & $\begin{array}{l}\text { Dark longitudinal cellular structure; shiny } \\
\text { coating; second order branches irregularly } \\
\text { ramified and of small diameter; hairy; } \\
\text { clustered and cone shaped root tips }\end{array}$ & $\begin{array}{l}\text { Arbuscular } \\
\text { mycorrhizae }\end{array}$ \\
\hline $\begin{array}{l}\text { Carpinus } \\
\text { betulus }\end{array}$ & $\begin{array}{l}\text { Dark red to } \\
\text { reddish brown }\end{array}$ & $\begin{array}{l}\text { Distinctive structured surface with } \\
\text { longitudinal furrows; square cellular } \\
\text { structure between furrows; strongly and } \\
\text { evenly ramified }\end{array}$ & $\begin{array}{l}\text { Ecto- } \\
\text { mycorrhizae }\end{array}$ \\
\hline $\begin{array}{l}\text { Fagus } \\
\text { sylvatica }\end{array}$ & $\begin{array}{l}\text { Orange brown } \\
\text { to dark } \\
\text { reddish brown }\end{array}$ & $\begin{array}{l}\text { Distinctive surface structure with wavy } \\
\text { longitudinal furrows; partly flaking } \\
\text { periderm; second order branches strongly } \\
\text { and evenly ramified; clustered root tips }\end{array}$ & $\begin{array}{l}\text { Ecto- } \\
\text { mycorrhizae }\end{array}$ \\
\hline $\begin{array}{l}\text { Fraxinus } \\
\text { excelsior }\end{array}$ & $\begin{array}{l}\text { Pale beige to } \\
\text { light grey, } \\
\text { yellowish }\end{array}$ & $\begin{array}{l}\text { Untextured and pale surface; second } \\
\text { order branches of relatively large } \\
\text { diameter, hairy; sparsely, but evenly } \\
\text { ramified }\end{array}$ & $\begin{array}{l}\text { Arbuscular } \\
\text { mycorrhizae }\end{array}$ \\
\hline $\begin{array}{l}\text { Prunus } \\
\text { avium }\end{array}$ & $\begin{array}{l}\text { dark brown to } \\
\text { beige }\end{array}$ & $\begin{array}{l}\text { unstructured spotted surface with square } \\
\text { cellular structure; evenly ramified }\end{array}$ & $\begin{array}{l}\text { Ecto- } \\
\text { mycorrhizae }\end{array}$ \\
\hline $\begin{array}{l}\text { Quercus sp. } \\
\text { (Q. petraea } \\
\text { and Q. robur) }\end{array}$ & $\begin{array}{l}\text { Beige to light } \\
\text { brown }\end{array}$ & $\begin{array}{l}\text { Fine crosswise structured shiny surface; } \\
\text { knotty swellings; long unramified } \\
\text { segments }\end{array}$ & $\begin{array}{l}\text { Ecto- } \\
\text { mycorrhizae }\end{array}$ \\
\hline $\begin{array}{l}\text { Tilia sp. } \\
\text { (T. platyphyllos } \\
\text { and T. cordata) }\end{array}$ & $\begin{array}{l}\text { Dark brown } \\
\text { to red brown }\end{array}$ & $\begin{array}{l}\text { Fine longitudinal cellular structure } \\
\text { between furrows; spotted surface; partly } \\
\text { transparent coating; evenly ramified }\end{array}$ & $\begin{array}{l}\text { Ecto- } \\
\text { mycorrhizae }\end{array}$ \\
\hline $\begin{array}{l}\text { Ulmus } \\
\text { glabra }\end{array}$ & $\begin{array}{l}\text { Orange brown } \\
\text { to yellow }\end{array}$ & $\begin{array}{l}\text { Indistinct structured surface with dark } \\
\text { longitudinal lines; square cellular } \\
\text { structure between dark lines, also visible } \\
\text { on finest rootlets }\end{array}$ & $\begin{array}{l}\text { Ecto- } \\
\text { mycorrhizae }\end{array}$ \\
\hline
\end{tabular}



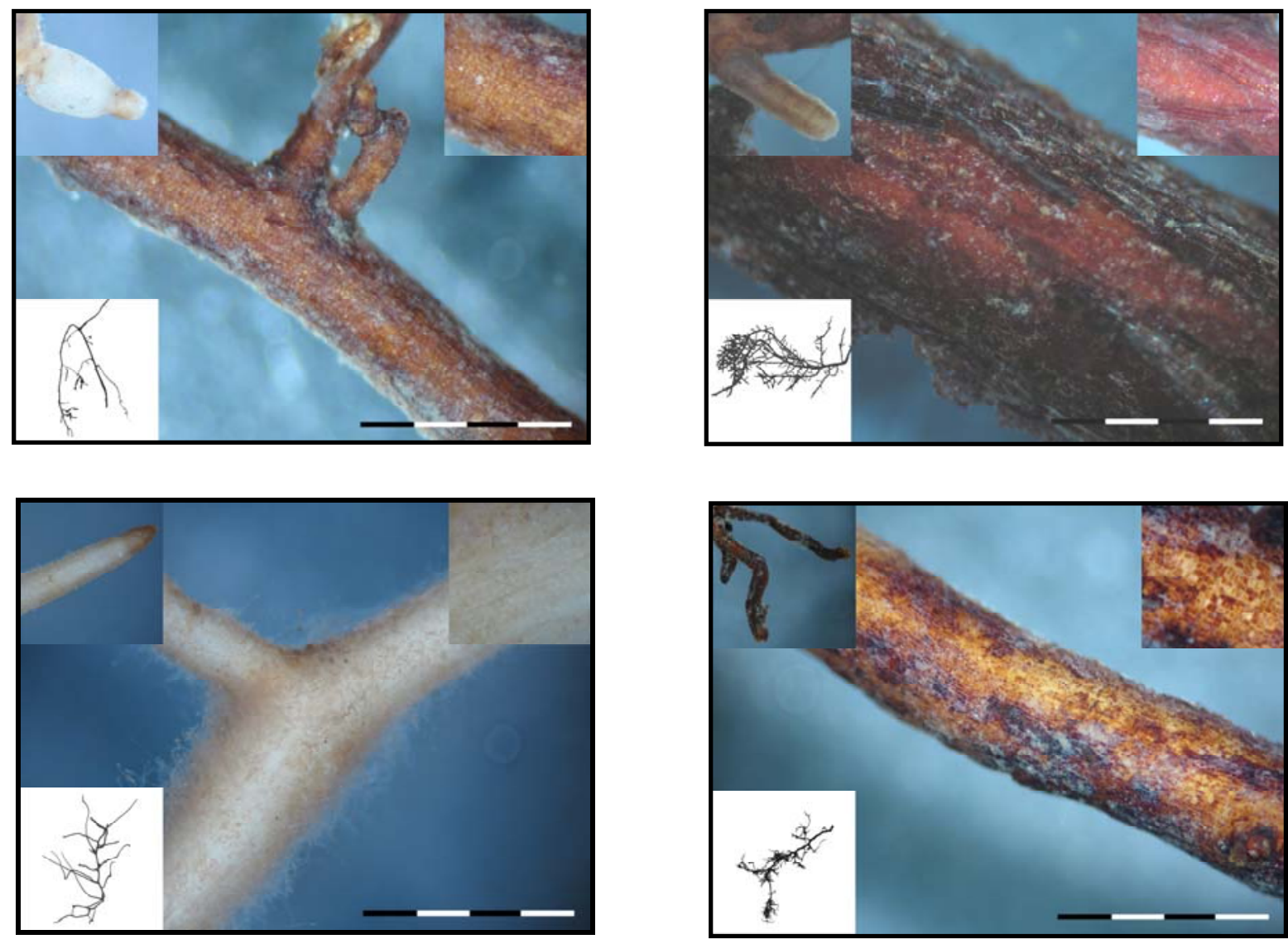

Appendix 2 Fine roots of Acer pseudoplatanus (top left), Fagus sylvatica (top right), Fraxinus excelsior (down left), and Prunus avium (down right). Presented are characteristics of the surface structure, the ramification pattern and the root tip. Pictures were made in cooperation with Boris Rewald. 


\section{Acknowledgements}

First of all, I would like to thank Professor Christoph Leuschner for providing me an interesting and sometimes challenging below-ground research topic. Many thanks for the constant support and the great interest for my work. Special thanks go to Dr. Dietrich Hertel for his countless help and support throughout the last three and a half years.

I am grateful to Professor Dirk Hölscher for reviewing this thesis and arousing my enthusiasm for the beautiful Hainich National Park during one of my first ecology courses.

I am especially thankful to all $\mathrm{PhD}$ students of the 'Graduiertenkolleg 1086' for having a great time in the Hainich and in Göttingen and for the extraordinary and excellent teamwork. In this context, I appreciate the cooperation with the management of the Hainich National Park, who give us the opportunity to work in this wonderful forest. Furthermore, I would like to thank the DFG for funding.

To all my colleagues of the Department of Plant Ecology: thank you for the very nice working atmosphere, the coffee breaks, and the long barbecue events. In particular, I would like to thank Mechthild Stange for field and lab assistance and Dr. Heinz Coners for providing technical support. Field work would have been much harder without Heiko Eichner, Nickolai Brock, and Alena Vacátková - thank you very much. Further, I would like to thank Nicholas T. Ryan for his fruitful work in Göttingen.

Special thanks to Dr. Dirk Gaul for shared office and root sorting times.

Without the big support of many people, finishing this $\mathrm{PhD}$ thesis would have been impossible. Many thanks to: Mascha Brauns, Jens Gabler, Tobias Gebauer, Barbara Geschwentner, Dr. Jasmin Lendzion, Ana Laura Moguel Velazques, Dr. Andreas Mölder, Dr. Boris Rewald, Inga Schmidt and Dorothea Schöling. Further, I would like to thank Juliane Tromm for her constant telephone support and for being there without being in Göttingen.

Special thanks to my family for the everlasting support and care during this $\mathrm{PhD}$ thesis. In particular, I would like to thank my sister Lisa for accompanying me during the ups and downs in the last years.

Finally, special thanks to Thomas Küttner for the endless and invaluable support. 


\section{Curriculum vitae}

\section{Personal details}

Date of birth:

December 26, 1976

Place of birth:

Wesel, Germany

Nationality:

German

\section{Education}

2005-2008

1998-2004

1997-1998

1987-1997

$\mathrm{PhD}$ study in Biological Diversity and Ecology at GeorgAugust-Universität Göttingen, Germany

Study of biology at the Georg-August University of Göttingen, Germany; Degree obtained: Diplom Biologin

Study of nutrition and food science at the Rheinischen Friederich Wilhelm-Universität Bonn, Germany

Euregio-Gymnasium Bocholt

High School graduation: Allgemeine Hochschulreife 